INTERNATIONAL MONETARY FUND

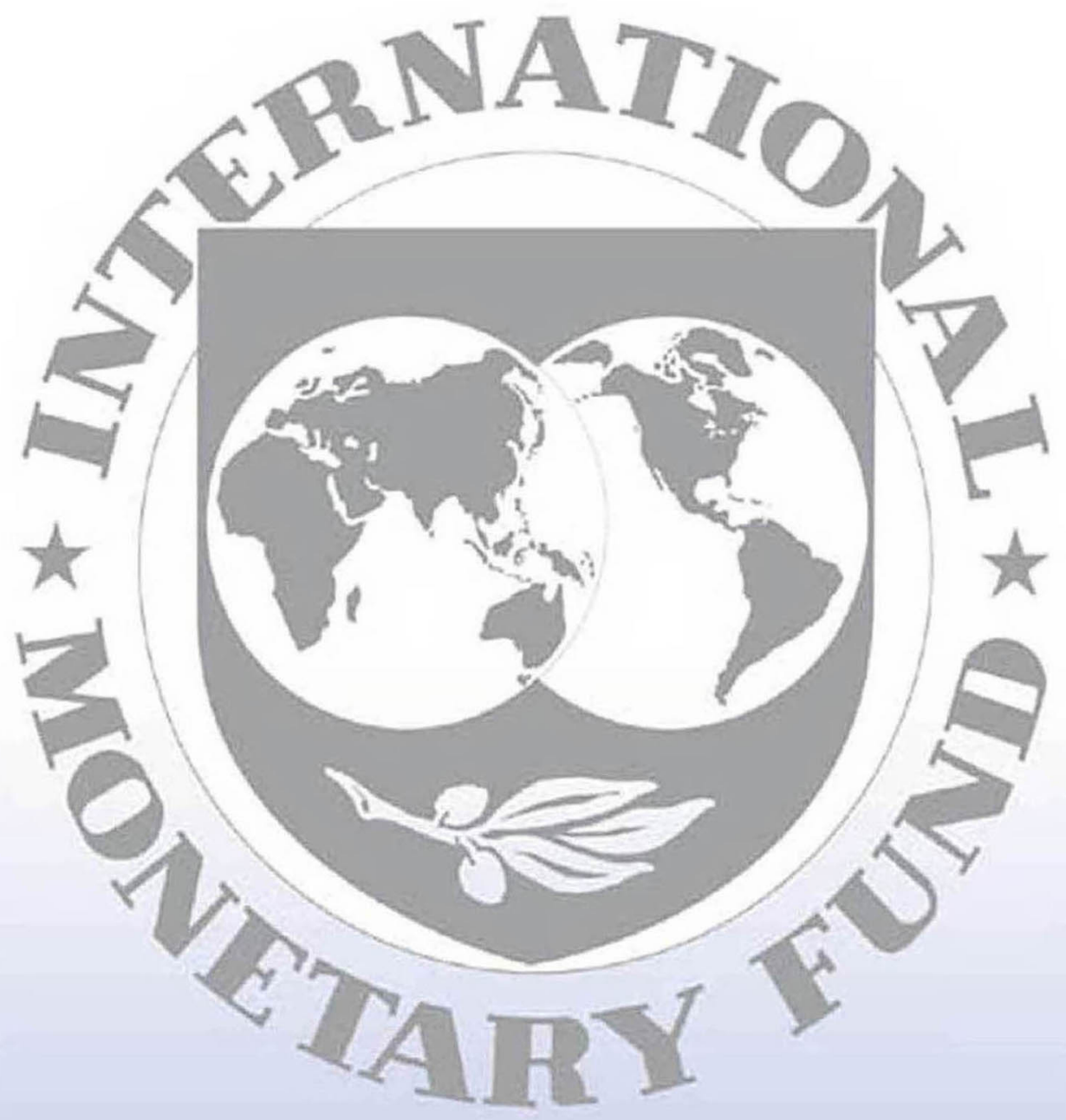

Staff

Country
Reports 


\title{
Portugal: 2012 Article IV Consultation and Sixth Review Under the Extended Arrangement and Request for Waivers of Applicability of End-December Performance Criteria-Staff Reports; Public Information Notice and Press Release on the Executive Board Discussion; and Statement by the Executive Director for Portugal.
}

The following documents have been released and are included in this package:

- $\quad$ The staff report for the 2012 Article IV consultation, prepared by a staff team of the IMF, following discussions that ended on November 20, 2012, with the officials of Portugal on economic developments and policies. Based on information available at the time of these discussions, the staff reports were completed on December 26, 2012. The views expressed in the staff report are those of the staff team and do not necessarily reflect the views of the Executive Board of the IMF.

- $\quad$ The staff report for Sixth Review Under the Extended Arrangement and Request for Waivers of Applicability of End-December Performance Criteria, prepared by a staff team of the IMF, following discussions that ended on November 20, 2012, with the officials of Portugal on economic developments and policies. Based on information available at the time of these discussions, the staff reports were completed on December 26, 2012. The views expressed in the staff report are those of the staff team and do not necessarily reflect the views of the Executive Board of the IMF.

- $\quad$ A Public Information Notice (PIN) and Press Release, summarizing the views of the Executive Board as expressed during its January 16, 2013, discussion of the staff reports.

- $\quad$ A statement by the Executive Director for Portugal.

The documents listed below have been or will be separately released.

Letter of Intent sent to the IMF by the authorities of Portugal*

Memorandum of Economic and Financial Policies by the authorities of Portugal*

Technical Memorandum of Understanding*

Letter of Intent to the European Commission and the European Central Bank*

Memorandum of Understanding on Specific Economic Policy Conditionality*

Selected Issues

*Also included in Staff Report

The policy of publication of staff reports and other documents allows for the deletion of market-sensitive information.

Copies of this report are available to the public from

International Monetary Fund • Publication Services

$70019^{\text {th }}$ Street, N.W. • Washington, D.C. 20431

Telephone: (202) 623-7430 • Telefax: (202) 623-7201

E-mail: publications@imf.org Internet: http://www.imf.org

\author{
International Monetary Fund \\ Washington, D.C.
}


This page intentionally left blank

CInternational Monetary Fund. Not for Redistribution 


\section{INTERNATIONAL MONETARY FUND}

\section{PORTUGAL}

\section{STAFF REPORT FOR THE 2012 ARTICLE IV CONSULTATION}

December 26, 2012

\section{KEY ISSUES}

Causes: The roots of the current economic crisis in Portugal can be traced to the failure to adapt to the rigors of monetary union. Instead of delivering on the promise of sustainable catch-up growth to EU living standards, monetary union facilitated the accumulation of economic and financial imbalances. The competitiveness of the tradable sector eroded. Policy responses were, at best, muted. Banks lost access to the wholesale funding market from mid-2010. And, in the first half of 2011, Portugal's government got shut out from financial markets.

Response: Portugal has mounted an impressive policy effort to gradually reverse the accumulated imbalances and forestall future crisis. A front-loaded fiscal adjustment program aims to restore credibility in government bond markets, while jump-starting external adjustment. Financial sector measures seek to keep banks well capitalized and liquid, while facilitating orderly deleveraging. A number of important structural reforms have also been implemented. And, despite some setbacks, underlying fiscal adjustment has advanced markedly; external account adjustment has also made significant strides.

Remaining challenges: There is broad agreement between staff and the authorities on the difficult policy challenges that remain. First, the near-term outlook remains uncertain with the economy likely to be in recession in 2013 and trading partner growth slowing. Second, maintaining and anchoring fiscal discipline and deleveraging private sector balance sheets still has some way to go and will be a source of headwinds for growth and employment. Third, fostering a more competitive tradable sectors while reducing excessive mark-ups in the non-tradable sectors requires politically difficult structural reforms. Overcoming these challenges will continue to test Portugal's so far remarkably sturdy social and political consensus. The country's success also hinges on continued strong European support.

Previous staff advice: The last Article IV report in December 2009 noted that Portugal needed to start consolidating its public finances, focusing on reducing the public wage bill and social transfers, while broadening tax bases; fiscal policy also needed to be anchored by a stronger legal and procedural framework, including a medium-term expenditure rule. It was also recommended that structural reforms focus on: (i) product market reforms to foster competition and productivity; (ii) a review of unemployment benefits to boost labor supply; and (iii) restraint on minimum wage increases to avoid pricing out low-skilled or young workers. But corrective policy actions were delayed. By the time they started to be implemented in mid-2010, tensions had already appeared in financial markets, which finally gave rise to a full-blown financial crisis. 


\section{Approved By}

Poul M. Thomsen and

Martin Mühleisen
Discussions took place during November 8-11 in Lisbon. The staff team comprised A. Aemro Selassie (head), D. Gershenson, M. Goretti, H. Lin, and S. Roudet (all EUR); A. Piris (SPR); A. Lemgruber (FAD); C. Verkoren (MCM); and A. Jaeger and M. Souto (Res. Reps). Mr. Cardoso (OED) also participated in meetings.

\section{CONTENTS}

BACKGROUND

A. Build-Up to the Crisis 4

B. Recent Economic Developments Z

C. Outlook and Risks

A. Policy Theme \#1: Addressing Accumulated Financial Imbalances $\underline{12}$

B. Policy Theme \#2: Restoring Competitiveness and Growth $\underline{15}$

STAFF APPRAISAL

\section{TABLES}

1. Selected Economic Indicators - Program Baseline $\underline{23}$

2a. General Government Accounts (Billions of euros) $\underline{24}$

2b. General Government Accounts (Percent of GDP) $\underline{25}$

3. General Government Stock Positions $\underline{26}$

4. Balance of Payments, 2009-17 $\underline{27}$

5. Selected Financial Indicators of the Banking System, 2007-12Q2 28

6. Monetary Survey, 2011-17 $\underline{29}$

7. External Debt Sustainability Framework, 2007-17 $\underline{30}$

8. Government Debt Sustainability Framework, 2008-30 $\underline{31}$

\section{FIGURES}

1. High Frequency Indicators $\underline{32}$

2. Labor Market Indicators $\underline{33}$

3. Competitiveness Indicators $\underline{34}$

4. Balance of Payments $\underline{35}$

5. Financing of the Economy, 2008-September 2012 $\underline{36}$

6. Financial Indicators $\underline{37}$

7. External Debt Sustainability: Bound Tests $\underline{38}$

8. Government Debt Sustainability: Bound Tests $\underline{39}$ 


\section{BOXES}

1. Gauging Tradable Sector Competitiveness $\underline{19}$

2. How Fast Can Portugal Grow?

3. Growth-Friendly, Equitable, and Sustainable Fiscal Reform in Portugal $\underline{21}$

4. Portugal's Corporate Leverage in Perspective

APPENDIX

I. Public Debts Sustainability $\underline{40}$ 


\section{BACKGROUND}

With a separate report covering developments under the program, this report on the Article IV discussions steps back to consider the causes of the current economic crisis and overall progress in addressing the long-standing economic challenges that Portugal faces. It starts with a discussion of how the country failed to take advantage of the opportunities offered by euro adoption, which required adapting to the new and demanding policy requirements of a monetary union. This background serves as a foil for assessing Portugal's present adjustment program and two broad economic policy challenges: the need to reduce the large financial imbalances in public and private sectors; and, given the limited policy tools, an exacting internal devaluation process to restore external competitiveness.

\section{A. Build-Up to the Crisis}

\section{In early-2011, mounting funding pressures tipped Portugal into an acute economic} crisis. While banks had already been shut-out from wholesale funding markets since mid-2010, as in other euro area periphery countries sovereign yields rose sharply, quickly followed by the Portuguese government losing access to the bond market. External financial assistance was needed to avert a full-blown financial crisis. The on-going EU/IMF-supported program is designed to provide Portugal with sufficient breathing space to implement the required adjustment and a wide range of reforms to mend the economy before re-accessing financial markets.

\section{But in fact the roots of the crisis can be traced to Portugal's failure to adapt to the} rigors of monetary union. By the early-1990s, Portugal's economic institutions and policies had been shaped by decades of monetary instability and financial repression. Against this backdrop, Portugal's rapid transition to economic and monetary union reduced sharply the real cost of credit, relaxed financing constraints, and raised income expectations. Euro adoption seemed to offer a launch pad for catch-up growth to EU living standards. But economic policies failed to adapt to the new institutional constraints, a prerequisite in the face of a rapidly changing and more competitive international environment. The competitiveness of the tradable sector eroded; public deficits and debt could not be tamed; structural reforms failed to lower high economic transaction costs; and private sector debt surged to exceptionally high levels. The economy found itself in a low growth trap, while rising private and public debts created serious vulnerabilities to a sudden stop in capital inflows—something that eventually happened fully in early 2011.
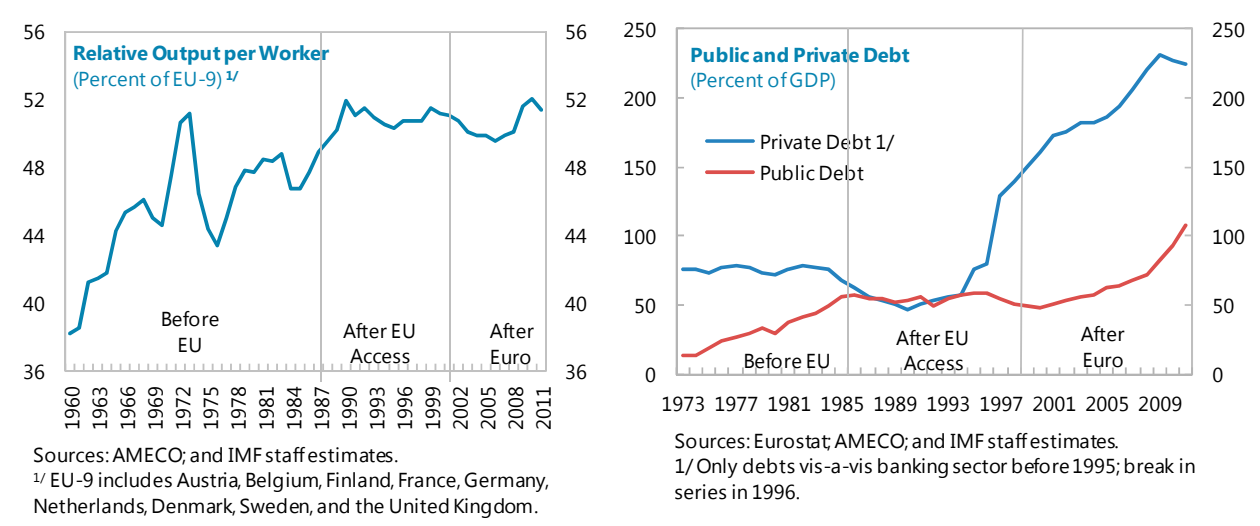
3. To be sure, Portugal was not alone in struggling to achieve sustainable catch-up growth within the new constraints of monetary union. The pace of productivity growth over the last decade in several euro area countries was too slow to achieve meaningful convergence towards living standards in the EU's higher-income countries. But uniquely in Portugal, surging levels of both private and public sector borrowing were accompanied by very limited output growth.

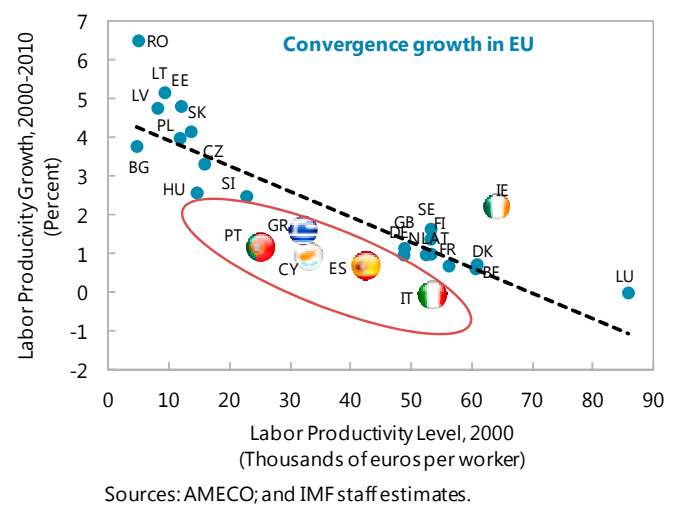

Sources: AMECO; and IMF staffestimates.

\section{Excessive private-sector leverage was facilitated by indulgent international capital} markets and domestic banks. Local banks intermediated most of the capital inflows needed to cover rising private financing gaps, largely borrowing on the interbank market to finance the expansion in corporate loans and household mortgages. With banks willing to assume this risky intermediation role, the non-financial corporate sector, and in particular the non-tradable sector, raised leverage to excessive levels. Rising leverage was accompanied by negative gross savings, mostly due to increasing labor and property costs as well as disproportionate investment in nontradable activities -including housing, energy, and highway infrastructure-misallocating real capital. At the same time, excessive financial leverage may have impaired corporate incentives to raise production efficiency.

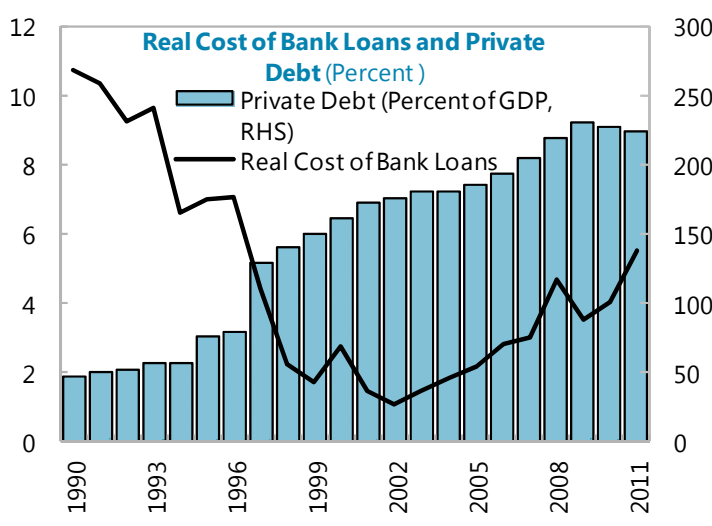

Sources: Eurostat, Banco de Portugal; and IMF staff estimates.

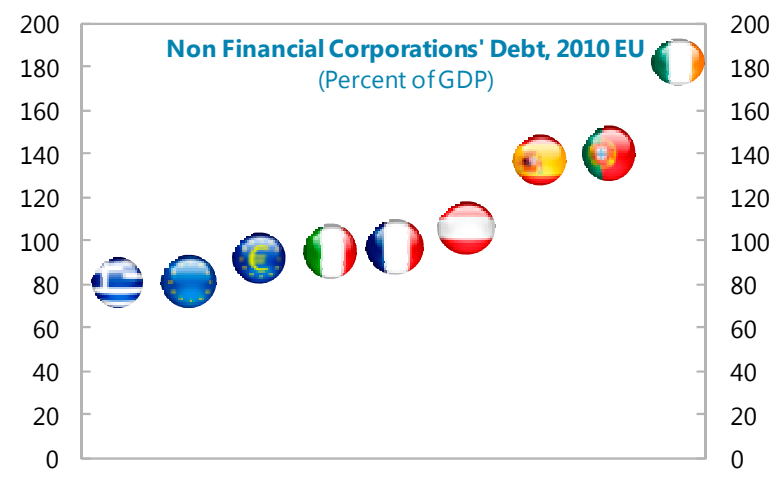

Source: Eurostat

5. Tradable sector competitiveness eroded. Staff estimates suggest that profit mark-ups in the tradable sector have been persistently lower than in the nontradable sector and that the gap in mark-ups in the nontradable sector widened further in the wake of euro adoption (Box 1: Gauging Tradable Sector Competitiveness). The high mark-ups in the non-tradable sector in part reflected lack of effective competition and regulatory policies, with entry barriers and informal networks

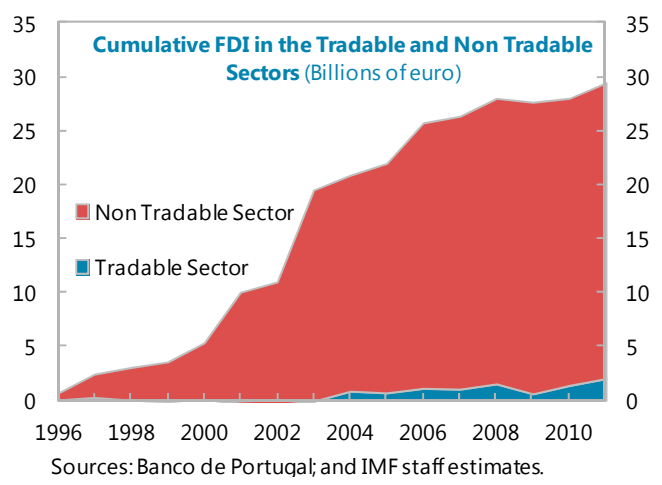


protecting a web of excessive rents. The situation was exacerbated by easy credit and rapid domestic demand growth, and EU transfers mostly absorbed by the non-tradable sector, particularly construction. The economy's lopsided reward structure induced a relative shift of labor and capital resources to the non-tradable sector, as also highlighted by the fact that virtually all net FDI inflows since 1995 went to the non-tradable sector.

\section{Lack of fiscal discipline added further strains to an already unbalanced growth process.}

Portugal's budgetary institutions remained largely unreformed during the transition to the euro and were unable to resist strong political economy biases toward increasing spending and debt in a setting of low interest rates and indulgent capital markets. The results were consistently overoptimistic budget revenue projections, unrealistic medium-term fiscal plans, and the shifting of spending obligations outside the budget process. In particular, social protection spending has surged since the mid-1990s, with little apparent pay-off in terms of improving income inequality. As a result and notwithstanding the EU's Stability and Growth Pact (SGP) rules, Portugal's fiscal policy after euro adoption remained unanchored, with headline fiscal deficits consistently exceeding the Maastricht three-percent deficit limit. A massive fiscal expansion in response to the global financial crisis added to the fragility of public finances.

\section{Growth was also constrained by other structural growth bottlenecks. An inefficient} public administration, particularly a slow-working court system, added to the economy's transaction costs. Moreover, a segmented labor market reduced the incentives for workers with temporary contracts to acquire skills, while labor market insiders enjoyed overly strong protections. Interacting with labor market segmentation, the social safety net created poverty traps for low-skilled unemployed, while a wage setting process dominated by non-tradable sector conditions tilted the playing field further against the tradable sector.

\section{With economic institutions, policies, and incentives ill-adapted to the opportunities} and constraints of monetary union, Portugal's external stability risks rose gradually. Portugal's external current account balance has traditionally been in large deficit. Reflecting high nominal GDP growth during the 1970s and 1980s, the international investment position remained close to nil until the 1990s, but then deteriorated precipitously, while the real exchange rate appreciated.

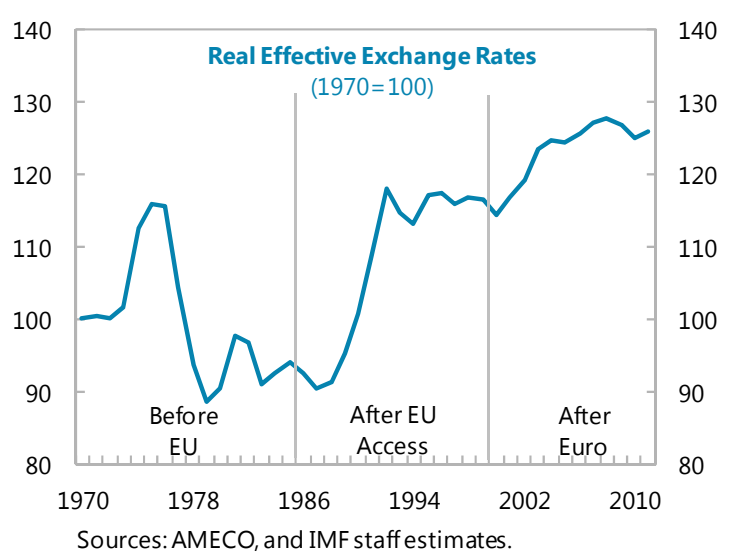

Sources: AMECO, and IMF staff estimates.

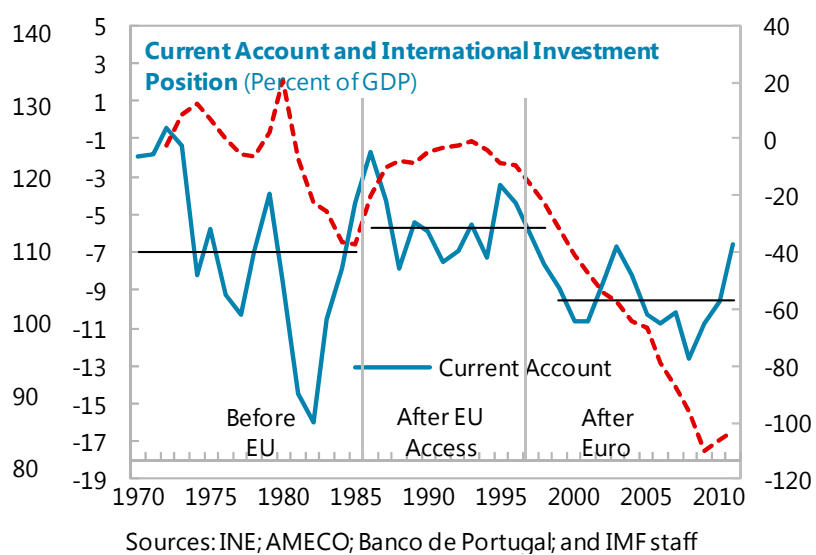

Sources: INE; AMECO; Banco de Portugal; and IMF staff 


\section{B. Recent Economic Developments}

\section{After a shallow recovery from the 2008-09 global financial crisis, activity reversed}

again in mid-2010. Portugal responded to the global financial crisis with strong fiscal stimulus, but the associated deterioration in public finances and rating downgrades forced an abrupt turnaround in the policy stance by mid-2010. With fiscal tightening, credit spreads rising, and external demand slowing, the economy slid back into recession. Unemployment continued to drift upward during the recovery; however, the deterioration in labor market conditions accelerated once firms came to a view that a permanent adjustment in their financial imbalances was unavoidable and started to reduce investment and labor costs to repair their over-leveraged balance sheets.

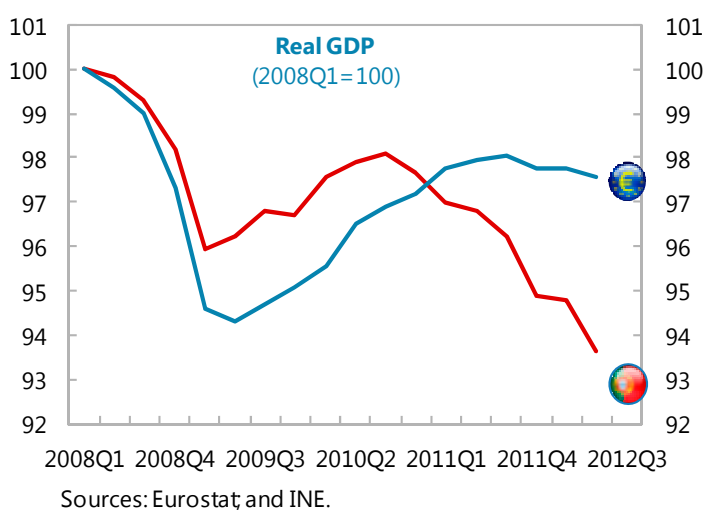

10. With financial imbalances being corrected across private and public sectors, the current account has improved substantially. Household and corporate financial imbalances had already started narrowing during 2009-10. Once the consolidation of public finances started in earnest as well, the external current account improved sharply. This reflected not just a compression of imports in response to slumping domestic demand, but also an expansion of exports, particularly to non-EU trading partners.

\section{Financial market sentiment deteriorated} through early-2012, but sovereign spreads have narrowed considerably since then. Spreads vis-à-vis Germany began to drift upward in 2010, culminating in a sudden stop in capital inflows and triggering the EU-IMF supported program. After peaking at almost 1500 basis points in January 2012, spreads reversed, reflecting both improving views on Portuguese prospects and evolving efforts to strengthen euro-wide crisis management.
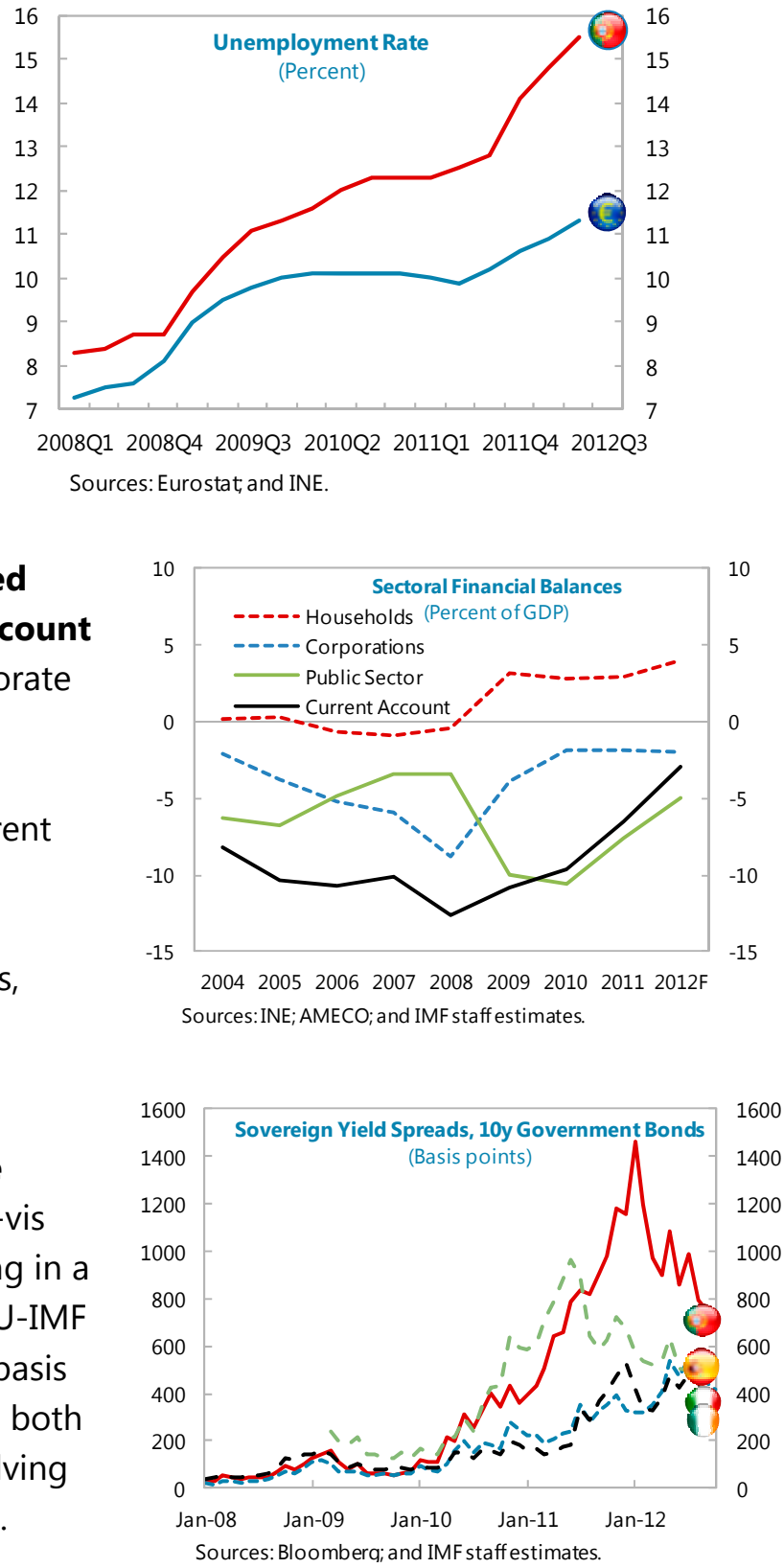


\section{The banking system has proven} resilient, but credit conditions of firms are significantly tighter than those faced by most other euro-area trading partners. Under the program, the liquidity situation of the Portuguese banks has remained adequate, supported by stable deposits, and continued Eurosystem liquidity support. However, while the necessary deleveraging under the program remains orderly, credit conditions, especially for small- and medium-sized enterprises, remain tight, with lending rates among the highest in the region.

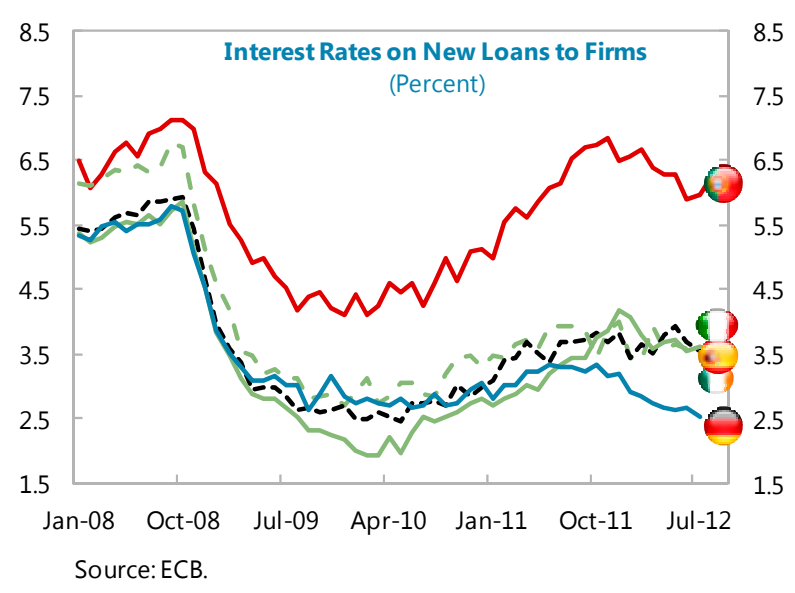

13. Fiscal adjustment has made substantial progress. A front-loaded fiscal adjustment effort was needed to turn the fiscal position around, and has led to a cumulative decline in the headline deficit of about 5 percent of GDP in 2011-12. Nominal deficit targets have proven difficult to achieve without one-off measures, both in 2011 and 2012. Nevertheless, the structural primary adjustment over these two years amounted to close to 6 percent of GDP, with across-the-board spending adjustment measures and a significant increase in the tax burden. Structural fiscal reforms have progressed, covering a wide range of measures on tax administration, public financial management, and containing fiscal risks from state-owned enterprises (SOEs) and private-public partnerships (PPPs).

14. Structural reforms are also progressing. A large number of growth-enhancing structural reforms have been legislated, but full implementation of many lies still ahead. There has been progress in: reaching a tri-partite agreement on labor market reforms, unclogging the court system, promoting competition, privatizing viable companies, and fostering an efficient rental housing market. Much less headway has been made on entry barriers and excessive rents in the non-tradable sectors, with limited progress in the energy markets.

\section{Outlook and Risks}

\section{Staff's Views}

\section{Portugal's short-term growth outlook} remains difficult, but the convergence process is expected to regain momentum over the medium term, as reforms start to bear fruit. Output is expected to contract by 3 percent in 2012, and the recession is likely to extend into 2013 , with a gradual recovery in the latter part of the year. Over the medium term, staff's baseline envisages growth to settle close to 2 percent by 2015, implying a moderate speed of convergence toward living standards in high EU income

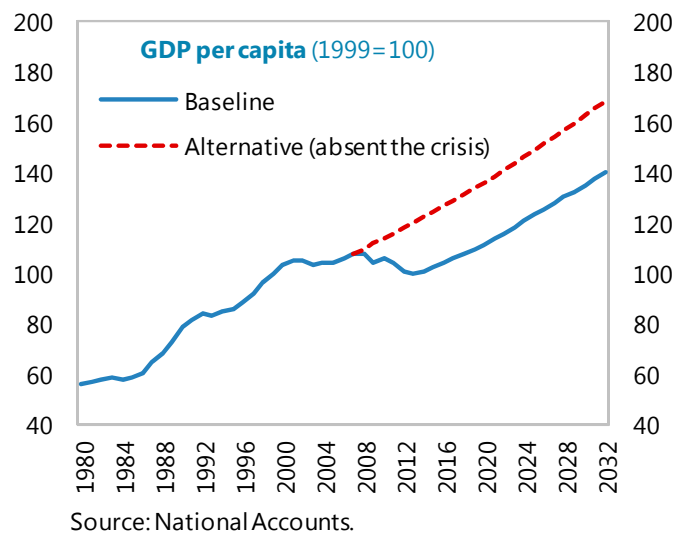


countries (Box 2: How Fast Can Portugal Grow?). While this moderate speed of convergence requires a significant improvement in productivity performance relative to earlier trends, this should be feasible in view of Portugal's still large distance from the international best-practice growth frontier and so far modest pay-off to the ongoing wide-ranging reforms. Nevertheless, Portugal's mediumterm output level is expected to settle about 20 percent below its pre-crisis trend.

\section{External adjustment is expected to continue, with the current account in broad}

balance in the medium term. Adjustment has taken place at a much faster pace than had been anticipated at the time of the last Article IV consultation (2009), which foresaw a current account deficit $7 \frac{1}{2}$ percentage points of GDP higher than is forecast for this year. The 2009 forecast also entailed a very gradual reduction in the current account deficit thereafter and a continuing deterioration of the negative IIP position to 135 percent of GDP at the end of the forecast horizon, compared to the current forecast of 90 percent in 2017. The current account adjustment to date has, however, been realized in the face of a relatively small improvement in relative prices. A key question thus is whether the improvement to date is simply cyclical or of a more durable nature. The fact that export growth has contributed to the lion's share of the adjustment does suggest that part of this adjustment should endure. But going forward only modest further relative price adjustment is assumed, raising the possibility that current account deficit could widen again with a recovery in economic activity. This is evident when one looks at the question from a savings-investment balance perspective. The adjustment is projected to be underpinned by stable private savings, investment staying at the historical low of 16 percent of GDP, and continued fiscal consolidation. In the presence of continued financing constraints, further relative price change would be required to restore external sustainability, implying a continuation of recessionary dynamics.

\section{Standardized estimates of exchange rate valuation point to declining overvaluation.}

The External Balance Assessment's (EBA) results point to only modest overvaluation under both the current account norm and real exchange rate approaches. While the macro balance approach (which considers the medium-term outlook for the current account in relation to a norm implied by fundamentals and policy settings) suggests there is no residual overvaluation, the real exchange rate and external stability approaches give more weight to the highly negative IIP position (-104 percent of GDP in 2011). Considering that external debt will need to fall over the medium term, these approaches are more suitable for Portugal. Reflecting the speed and size of the external adjustment to date, these approaches point to modest but declining overvaluation.
External Balance Assessment

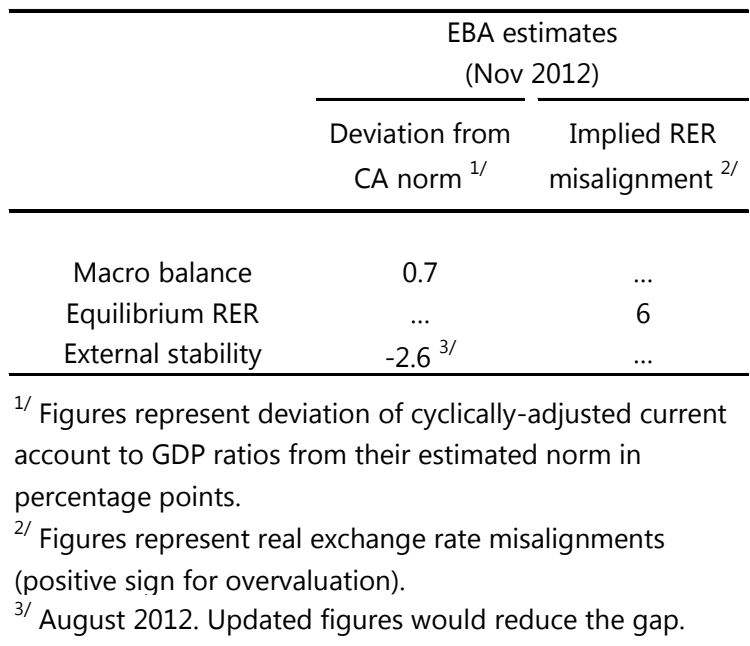




\section{The containment and gradual reduction of public debt at the heart of Portugal's} current IMF/EC-supported program. On current policies and outlook, public debt is projected to peak at around the 122 percent of GDP mark in 2013 and 2014, before gradually declining to below 110 percent of GDP by 2020. The debt path remains very sensitive to the economic growth and interest rate assumptions. As noted in Appendix I, the combination of plausible shocks could generate an unsustainable dynamics. The external debt of both the public and private sectors is also expected to peak in 2013-at some 237 percent of GDP_declining markedly thereafter, including on account of the ongoing deleveraging by the private

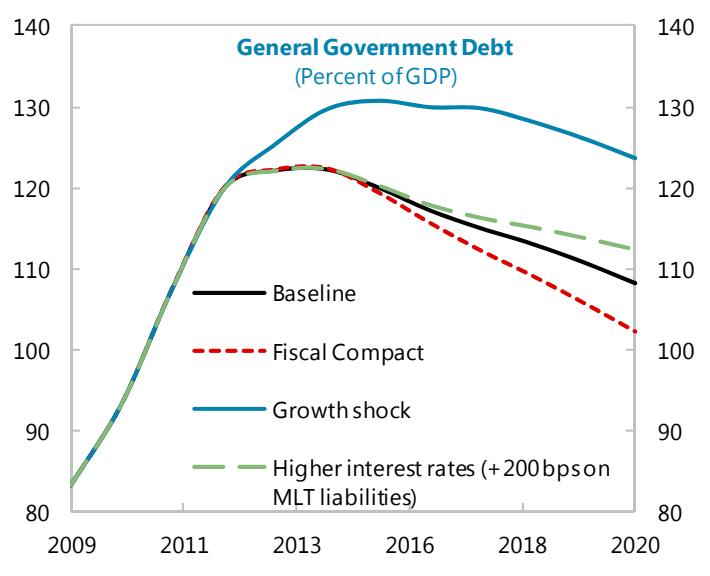
sector.

19. However, downside risks to these projections are significant. A range of safeguards are in place to mitigate these risks —including the commitment by European leaders to provide adequate support to Portugal until market access is restored, provided the program is on track. But, particularly if these risks were to materialize simultaneously a reassessment of the current program strategy might be unavoidable:

- with activity and confidence indicators still negative, fiscal adjustment could curtail growth even more than the mission's revised and now more conservative assumptions allow for. Similarly, and while projections are already conservative, corporate deleveraging could weigh on aggregate spending and employment even more than is assumed in the present baseline.

- with core European markets slowing, the risk of weaker demand for Portuguese exports is elevated despite consistent growth in other markets. And, progress on addressing euro area policy fissures could disappoint, with renewed detrimental effects on confidence and prospects for a recovery in investment.

- progress in restructuring SOEs and the relatively orderly deleveraging witnessed so far, migration of contingent liabilities from either state-owned enterprises or the private sector to the sovereign balance sheet remains a possibility.

- some of the fiscal measures under the program could be challenged on constitutional grounds, as happened in 2012. Should this be the case, the authorities stand ready to enact alternative measures to ensure the fiscal program remains on track.

- political and social consensus could weaken further, undermining the government's ability to stay the course of fiscal adjustment and structural adaptation.

20. Portugal needs to successfully mitigate these risks in order to avoid spillovers to the rest of the euro area. The Portuguese economy is highly dependent on developments in Europe- 
reflecting both strong trade and financial links-but the euro area in particular would also be affected by adverse developments in Portugal should the current program strategy fail. Contagion has been quick to spread among the euro area periphery countries but also to other euro area members in the past couple of years, including through rising asset price correlations and deteriorating confidence and some reversal in financial integration. It is thus imperative that the Portuguese authorities implement the program to the fullest extent possible to avoid the emergence of renewed stress in the euro area. At the same time, particularly if such implementation of the program fails to engender the desired results, it will be important for European partners to provide the support required to ensure the program remains fully financed. Clearly, progress in the implementation of the policies currently under discussion to strengthen the architecture of the euro area, including crisis resolution mechanisms, would also facilitate program implementation in Portugal.

\section{Authorities' Views}

21. The authorities saw some upside risk to these projections. They are confident that the reform efforts already in train will be sufficient to re-balance profit mark-ups in the tradable and non-tradable sectors at levels consistent with achieving external stability, pointing to the large and rapid adjustment in the current account since the start of the program. In addition, they also pointed to the large educational and structural policy gaps, which although acting as constraints in the short-term are also a source for rapid catch-up hope in the medium- to long-term. Under these circumstances, they saw upside risks to both medium-term growth and external adjustment projections.

\section{POLICY DISCUSSIONS}

There was agreement between staff and the authorities on the main causes of the current crisis and policies to address them. On the causes, with the benefit of hindsight, it is was agreed that it included: (i) the lack of any convergence growth since the late-1990s, with growth in Portugal about the same as in other northern European members of the euro area; (ii) consumers, businesses, and the public sector, however, behaving as if convergence growth was taking place and borrowing heavily at the low interest rates facilitated by membership of the EA; and (iii) the resulting higher spending having induced a real exchange rate overvaluation and a large debt overhang. With the real exchange rate and leverage clearly out of line with the economy's growth capacity, the onset of the global financial crisis drove the economy further away from the convergence growth path, eventually triggering the 2011 crisis. There was also consensus that, while economically and socially difficult, policies now need to be geared toward unwinding public and private sector imbalances to lay the grounds for a durable recovery. Relatedly, in the context of the monetary union, reforms to engineer a strong supply response are the only way to make the economy more competitive and return to a convergence growth path. The Article IV discussions consequently focused on key elements of these two broad policy objectives. 


\section{A. Policy Theme \#1: Addressing Accumulated Financial Imbalances}

\section{The Road to Fiscal Responsibility}

\section{Restoring and anchoring fiscal discipline poses two challenges:}

- Keeping fiscal adjustment on track. Some two-thirds of the required fiscal adjustment targeted under the program has been effected, but a sizeable adjustment effort still lies ahead. The extensive reliance on large income tax increases in the 2013 budget has created considerable disquiet. Hence, finding the right combination of spending and revenue measures will remain at the forefront of the adjustment program. The objective remains a gradual reversal in the upward trend in public debt to ensure debt sustainability and allow timely re-access to financial markets. As evidenced by a recent Constitutional Court ruling regarding public wage and pension cuts in the 2012 budget, fiscal adjustment measures need to meet legal criteria that are at times difficult to anticipate.

- Anchoring fiscal responsibility. This requires strengthening the budgetary framework, in line with Portugal's obligations under the EU's fiscal compact.

\section{Staff's Views}

23. While the need for further fiscal adjustment is not controversial, public discussion is needed to reach consensus on what levels of spending and taxation the country wants. The public expenditure review that is underway should help identify additional spending adjustment options that lead to fair burden sharing. This would help rebalance the adjustment mix and bring it closer to the original objective-one third revenue, two thirds expenditure. Given that Portugal's spending is heavily concentrated on social transfers and public wages, accounting for about twothirds of the total (Box 3: Growth-Friendly, Equitable, and Sustainable Fiscal Reform in Portugal), these outlays will have to be the focus of the core of spending reforms. Moreover, relatively high public employment, high wage premium in comparison to the private sector, and more generous pensions than in peer countries alongside limited old-age poverty alleviation, suggest that spending cuts can be implemented while increasing efficiency and equity. On the tax side, the tax-to-GDP ratio is already in line with what would be expected for Portugal's development levels. Given that the 2013 budget will push this ratio even further, additional revenue-mobilizing measures are not recommended. Nevertheless, there is scope to implement a growth-oriented tax reform, which should reduce distortions through streamlining and targeting tax expenditures, and to strengthen tax compliance, including through greater use of the anti-money laundering framework. ${ }^{1}$

\section{Anchoring fiscal discipline over the medium and long term will require setting reform} priorities. Much has already been achieved in addressing deep-seated public financial management weaknesses, such as insufficient fiscal reporting, restricted budgetary coverage, inadequate PPP

\footnotetext{
${ }^{1}$ SI Chapter III.
} 
legal framework, and ineffective expenditure commitment controls. However, a large agenda still lies ahead. This includes for instance reducing budget fragmentation, improving the medium-term fiscal framework -including by making it consistent with the EU fiscal compact-and moving towards accrual accounting. The authorities' 2013-15 public financial management strategy is an important instrument establishing priorities to guide this comprehensive reform. Continuing to build up a stronger implementation capacity at the Ministry of Finance will also be important.

\section{Authorities' Views}

\section{Re-thinking of the roles of the state is necessary to bring expenditure down to a} sustainable level. Apart from achieving the deficit targets, lowering the primary expenditure-GDP ratio substantially over the medium term will generate fiscal space for growth-enhancing capital expenditure and to allow a gradual reduction of the tax burden. This will require a re-thinking of the allocation and distribution functions of the state. Reducing expenditure in line with these aims will be a complex political process. This process will have to be open and transparent, and the end result consistent with Portugal's social consensus to preserve a welfare state.

\section{The authorities would have preferred to anchor fiscal discipline with a hard} constitutional balance rule, but there was no political consensus for this route. Mindful of Portugal's long-standing political economy biases toward higher spending and deficits, the Portuguese authorities argued, both at the European and the domestic level, for a constitutional amendment to underpin future fiscal discipline. Amending the Portuguese constitution would have been, however, fraught with procedural difficulties, and it was also not possible to achieve sufficient political consensus. Instead, the EU fiscal compact will be implemented via the budget framework law, likely with broad political support.

\section{Deleveraging Private-Sector Balance Sheets}

27. The corporate sector is under strong pressure to deleverage, posing downside risks to growth, bank profitability, and the sovereign balance sheet. As illustrated by the experience in other countries, corporate deleveraging is expected to be protracted, taking a continued toll on investment, while efforts to cut labor cost could drive up unemployment further (Box 4: Portugal's Corporate Leverage in Perspective). In addition, adverse shocks relative to the baseline, including to growth or funding costs, could provoke a disorderly deleveraging process, raising corporate default rates and bank losses.

\section{Banks are facing a number of vulnerabilities, and will need to change their business} model to avoid a new leverage cycle. Several of the large banks have a need to gradually deleverage their balance sheets, allowing them to reduce dependence on Eurosystem liquidity support over the medium term. Moreover, banks face a further erosion of their profitability as a result of weak credit conditions and high funding costs. In the near term, the low mortgage interest rate environment will continue to put a drag on bank profitability, underlining the importance of cost discipline. At the same time, there is a need to maintain the supply of credit to healthy firms in 
order to avoid credit constraints causing irreparable damage to firms that are in a position to contribute to the economic recovery.

\section{Staff's Views}

\section{The corporate deleveraging process poses significant challenges, but there are tools to} manage associated risks. In particular, the risks can be mitigated by working on three fronts. First, keeping banks sound. The central bank's regular supervisory inspections and stress test exercises aim at ensuring banks have adequate capital under the current baseline and are able to withstand adverse shocks. Moreover, additional buffers are already envisaged under the program, in case further capital needs were to arise. Second, effectively implementing the new corporate and household debt restructuring frameworks. Corporate debt restructuring is a critical element of the deleveraging process to ensure viable firms can effectively sustain the economic recovery. In this regard, the new corporate restructuring toolkit aims at reducing the risks of cumbersome court procedures, by introducing fast-track and out-of-court procedures. However, ongoing efforts are needed to monitor the effective application of the new toolkit, notably to set the right incentives for firms to apply for restructuring well before their viability becomes at risk. Finally, the supervision and regulatory frameworks can be used to limit ever-greening and ensure that credit flows to the most dynamic enterprises.

30. To avoid another leverage cycle, several medium-term measures are in order. First, the ongoing deleveraging process is expected to gradually reduce banks' reliance on non-deposit funding and prevent a reemergence of excessive asset growth. Second, use of macro-prudential policy tools, such as net stable funding and leverage ratios (consistent with Basel III requirements), as well as more targeted tools, such as sectoral risk weights or loan-to-value caps, can help to counteract a renewed buildup of excessive leverage of bank balance sheets. Third, the larger banks are actively pursuing measures to rationalize their operations, with particular focus on reducing the cost base of their domestic retail networks, which are characterized by a relatively high number of branches per inhabitants, and improving profitability. Strict cost control would be especially important if the projected increase of the banks' interest income would not materialize.

\section{The Authorities' Views}

\section{The key priority is to improve credit conditions and costs for Portuguese companies.}

Credit markets in the euro area are presently fragmented, with uneven credit conditions for companies with similar fundamentals. This puts Portuguese companies at a severe competitive disadvantage inside the monetary union. This problem should be addressed at both the euro area and Portuguese levels: segmentation of credit markets in the euro area needs to be corrected, mainly by removing excessive sovereign risk premia which are hampering the effectiveness of the monetary transmission mechanism; and, at the Portuguese level, high credit spreads also reflect informational inefficiencies at the banks' level. Portuguese banks' credit risk evaluation before the crisis largely reflected subdued risk aversion at a global scale, which has significantly increased in the present environment. Initiatives to promote information sharing, for example through establishing a privately-run and publicly-available credit rating system, could help alleviate informational 
inefficiencies, notably for SMEs, and support a more effective pricing of risks by banks. In parallel, steps are being taken to promote firms' access to capital markets and alternative funding options, through specialized institutions and structural funds. Securitizing mortgage portfolios could also help take pressure off banks to compensate for low mortgage spreads through higher corporate lending spreads.

\section{B. Policy Theme \#2: Restoring Competitiveness and Growth}

32. Restoring tradable sector competitiveness requires lowering costs across both tradable and non-tradable sectors, and reducing excessive mark-ups in non-tradable sectors. Unit labor cost will remain under pressure from high unemployment and low vacancies, and impetus to productivity growth due to firm restructuring and structural reforms should also help lower costs. A more competitive tradable sector could provide the main growth engine to bring Portugal closer to the best-practice international growth frontier. But it is also important that structural reforms in the non-tradable sectors provide incentives to innovate and cut costs, steps that would lower intermediate input costs in the tradable sectors. Finally, the public sector needs to contribute more to facilitate economic dynamics and risk taking, including through court reforms and appropriate incentives to promote tradable sector activities. Reducing administrative burden and red tape is also important to boost non-price competitiveness.

33. The longer-term growth outlook will also depend on tackling deeper-seated growth bottlenecks, in particular Portugal's human capital gap. In spite of significant progress in raising the education of the new flows into the labor force, Portugal's labor force as a whole remains among the least educated in the OECD. Closing this gap will take a long time and requires a sustained multi-year effort. Relatedly, if the recent increase in emigration-particularly that of the younger and better-educated population-over the past two years continues into the medium- to long-term, it will further constrain the contribution from human capital directly as a factor input and indirectly through lower total factor productivity growth.

\section{Staff's Views}

34. Significant improvements in external competitiveness through cost channels have already been set in train. Although the fiscal devaluation has not been possible, progress has been made in lowering labor cost. Recent measures in the labor market to reduce high employment protection and increase incentives to work should further support these gains. The reform that phases out rent control will enhance labor mobility. Judicial and licensing reforms under consideration should also help lower costs of doing business, making Portugal a more attractive investment destination.

\section{The program has so far been less successful in increasing incentives towards the} tradable sector. This largely reflects the absence of policy levers but also procedural difficulties in rolling back excessive rents in sheltered sectors (network industries for instance). The reduction in labor and other production costs achieved under the program so far have been beneficial to both the tradable and nontradable sectors. Moreover, the risk is that further labor and credit cost 
reductions would again lead to the sheltered sector attracting a disproportional share of the economy's resources, including FDI, owing to the persistently excessive non-tradable mark-ups. While stricter enforcement of competition laws and regulations will clearly help, including by providing the relevant regulatory agencies with the needed independence and resources, a more forceful approach may well be required. If growth remains lopsided towards non-tradable activities, more intrusive regulatory approaches coupled with a reexamination of existing contracts in network industries may be unavoidable.

36. As a more competitive tradable sector emerges, catch-up growth will have to rely on gradually closing the human capital and structural policy gaps. The medium-term growth outlook requires higher productivity growth than experienced in the past decade, and this can be achieved through timely and effective implementation of the package of structural reforms under the current program.

\section{The Authorities' Views}

\section{External competitiveness is being restored faster than widely acknowledged. In}

particular, fiscal adjustment and corporate deleveraging are putting pressure on non-tradable prices, reversing the earlier process of declining competitiveness. Firms-including traditionally domestically-oriented-are fast adapting to the domestic economy conditions, seeking new markets abroad. And the impact of this is already evident in the sharp improvement in the current account balance, which is more structural than cyclical. Moreover, over the medium term, improved competition regulation has a key role to play. A more efficient state is another key ingredient for a more competitive economy, including by channeling EU funds to more productive uses than in the past.

38. If the policy reforms underway stick in the medium term, they will fundamentally tilt the institutional playing field toward fostering sustainable catch-up growth. Loose fiscal policies and easy credit conditions in the past had created an illusion of converging living standards, when in fact these policies underpinned growing financial imbalances and mis-allocated the economy's resources to activities with low social rates of return. The program has not only initiated a wide range of structural reforms to overcome key growth bottlenecks and attract tradable sector FDI, but it should also help durably correct the biases that rewarded policy makers for choosing policy recipes that were popular in the short run, including at elections, but proved ultimately unsustainable in the long run.

\section{STAFF APPRAISAL}

39. Portugal's current economic predicament is the legacy of policy failures in the face of a rapidly changing environment. Economic institutions and policies proved ill-adapted to the demands and opportunities of monetary union and globalization. The rapid transition from decades of financial repression and monetary instability proved difficult. Monetary union, instead of delivering on the promise of sustainable catch-up growth to EU living standards, facilitated the accumulation of economic and financial imbalances. The competitiveness of the tradable sector 
eroded. Abetted by a banking system prone to allocating too much credit and mispricing risks, leverage in the non-tradable sector increased markedly, notwithstanding weak productivity growth. The public sector in turn financed rapidly growing spending, particularly on social protection, through higher taxes and accumulating debts. Policy responses were, at best, muted. Banks lost access to wholesale funding in mid-2010. And, in the first half of 2011, Portugal's government was shut out from financial markets.

\section{In response, the Portuguese authorities have mounted an impressive policy effort to} gradually reverse the accumulated imbalances and forestall future crisis. A front-loaded fiscal adjustment program is aiming at restoring credibility in government bond markets, while jumpstarting external adjustment. Financial sector measures seek to keep banks well capitalized and liquid, while facilitating orderly deleveraging. And structural reforms, ranging from reforming inefficient courts to phasing out rent controls, aim to revitalize the economy's supply side. Considerable progress has already been made. In spite of setbacks, underlying fiscal adjustment has advanced markedly; external account adjustment has also made significant strides.

\section{Yet the near-term outlook is uncertain, and sizable medium-term economic challenges} remain. With trading partner growth slowing, the economy will likely be in recession in 2013, while unemployment will rise further from the already record high levels. Beyond the short term, maintaining and anchoring fiscal discipline and deleveraging private-sector balance sheets will remain imperatives, but also generate headwinds for growth. In particular, fiscal adjustment needs to continue, although revenue shortfalls-partly reflecting a more rapid external adjustment and a less favorable tax base composition-have delayed the achievement of the original nominal deficit path. Fostering more competitive tradable sectors while reducing excessive mark-ups in the nontradable sectors requires politically difficult structural reforms. Overcoming these challenges will continue to test Portugal's so far remarkably sturdy social and political consensus.

\section{Given the still significant fiscal adjustment ahead, further public debate is needed on how to share the burden of remaining fiscal adjustment fairly and in a growth-friendly} manner. Fiscal spending, particularly on public wages and social transfers, ratcheted up for many years, with a weak link between the state's goals and the budget's spending allocation. The main focus will have to be on further rationalizing public sector pay and employment as well as reforming pensions and other social transfers, aiming at more efficient public services and more equitable redistribution. At the same time, while it will be difficult to reduce the overall tax burden in the coming years, there is scope to reduce tax distortions, simplify the tax system, and strengthen tax compliance. A broader tax base would allow reducing the current high income tax rates, including of the corporate income tax, to help attract more FDI. Beyond progressing on fiscal adjustment, anchoring fiscal responsibility will require a much stronger budgetary framework. The obligation to implement the EU fiscal compact offers a good opportunity to reach political consensus to hard-wire budgetary prudence into the country's legal fabric. Maintaining the efforts to strengthen oversight and control over revenue mobilization and public financial management will also be critical to deliver on budget promises. 


\section{While the over-indebted private-sector is gradually adjusting, high debts still pose} risks to growth and bank profitability. Corporate sector deleveraging is essential to restore firms' productivity and growth, but it is expected to take time and lower prospects for investment in the short to medium term. While adequate banks' buffers have managed to prevent an abrupt adjustment, risks of adverse shocks raising corporate defaults and resulting in additional bank losses remain. Private household leverage appears more manageable, also reflecting the absence of a past housing bubble in Portugal and low mortgage rates, but also calls for close monitoring given rising unemployment and income losses.

\section{To lower the risk of a renewed run-up in private indebtedness, Portugal needs to} sustain the ongoing reforms to foster a sound financial system. Bank deleveraging is expected to reduce banks' reliance on non-deposit funding. In addition, the proactive use of macro prudential policy tools could help forestall excessive bank asset growth. Moreover, banks need to continue rationalizing process, focusing on reducing the cost base of their domestic operations. Initiatives to promote capital markets can also help diversify firms' funding structure. Finally, tax policy initiatives could lower the bias of firms toward debt-financing over the medium term.

\section{A more competitive tradable sector is the key to sustaining growth and reducing high} unemployment over the medium term. As highlighted by the experience of other countries, particularly in the EU, a competitive tradable sector that is well integrated into regional and global supply chains is the most effective engine for sustainable convergence growth. Progress on this front requires structural reforms across all sectors that target growth bottlenecks, reduce production costs, and compress excessive profit mark-ups in the non-tradable sector. While the external current account deficit narrowed at an unexpectedly fast pace over the last two years, this welcome development still needs to be locked in by a durable improvement in the country's competitive fundamentals. The program's structural reform agenda goes some way towards doing this. But additional steps may be needed to increase the momentum and depth of reforms, which could include additional targeted incentives to promote tradable sector activities.

\section{Success of the program will also depend on whether European policymakers forge} ahead with reforms to overcome euro area fissures. While implementation of the adjustment program remains the key for mending Portugal's own deep-seated economic problems, these domestic efforts will need to be complemented by reforms of euro area arrangements to clear a path not only toward a durable return to market financing for Portugal but also to avoid a repeat of the build-up of unsustainable imbalances in the future. The public commitment by European leaders to render adequate support to Portugal until market access is restored, as long as the program is on track, provides a valuable safety net. To overcome credit market segmentation and restore an appropriate monetary policy transmission, it would also be important to further clarify the steps Portugal would need to take, as the country starts regaining bond market access, before qualifying for the ECB's Outright Monetary Transactions.

\section{The next Article IV consultation is expected to take place on a 24-month cycle.}




\section{Box 1. Portugal: Gauging Tradable Sector Competitiveness ${ }^{1}$}

Why did virtually all FDI over the last fifteen years flow into Portugal's non-tradable sector, while before 1995 about one third of total FDI went to the tradable sector? Staff estimates of average pre-tax profit markups for the tradable and non-tradable sectors since 1995 indicate that relatively high mark-ups in the nontradable sector were a key driver behind the lop-sided allocation of FDI inflows.

Estimates of average profit mark-ups for the tradable and non-tradable sector represent a useful complement to more conventional real exchange rate analysis. In particular, mark-ups provide a summary measure of both price and unit cost developments in

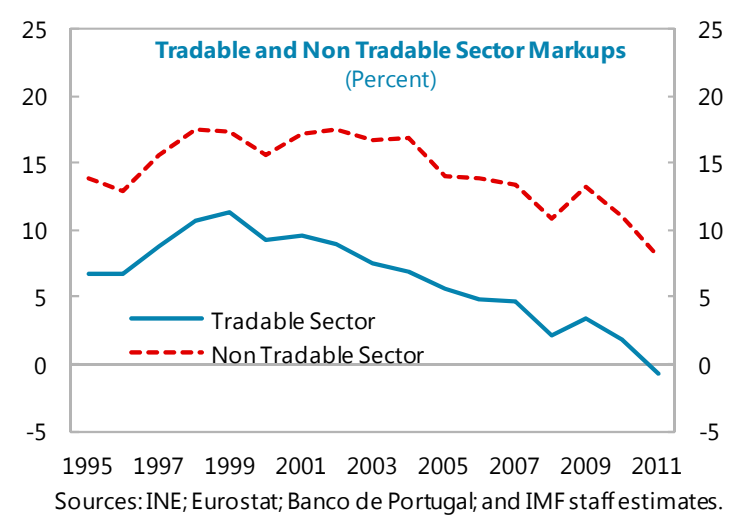
the tradable and non-tradable sectors, developments that otherwise would require analyzing a number of separate and sometimes difficult-to-interpret real exchange rate measures. ${ }^{2}$

To calculate mark-ups, the economy was partitioned into three sectors: (1) tradables; (2) non-tradables that produce goods and services for markets; and (3) non-tradables that are not produced for markets. The third sector includes mainly public sector services, and the relevant mark-up comparison is only between sectors (1) and (2). The mark-up estimates are based on detailed input-output table data and gauge the profit as a percentage of total cost, i.e. the sum of the cost of labor, capital, and intermediate inputs. For Portugal, the trends in the sectoral profit mark-ups over time reflected two main factors:

- Unit capital costs fell sharply in both sectors around the time of euro adoption, boosting temporarily mark-ups across all sectors, but then increased gradually, reflecting rising depreciation charges and higher cost of credit. High unit capital costs presently represent a major drag on the profitability of the tradable sector.

- Unit labor cost in the non-tradable sector increased also fast, but remained under relatively firm control in the tradable sector. However, the relatively favorable unit labor cost developments in the tradable sector were not sufficient to prevent the gradual compression of tradable sector mark-ups.

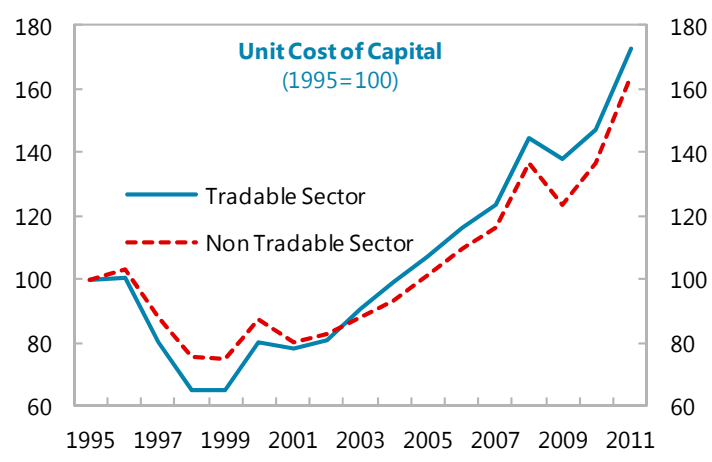

Sources: INE; Eurostat; Banco de Portugal; and IMF staff estimates.

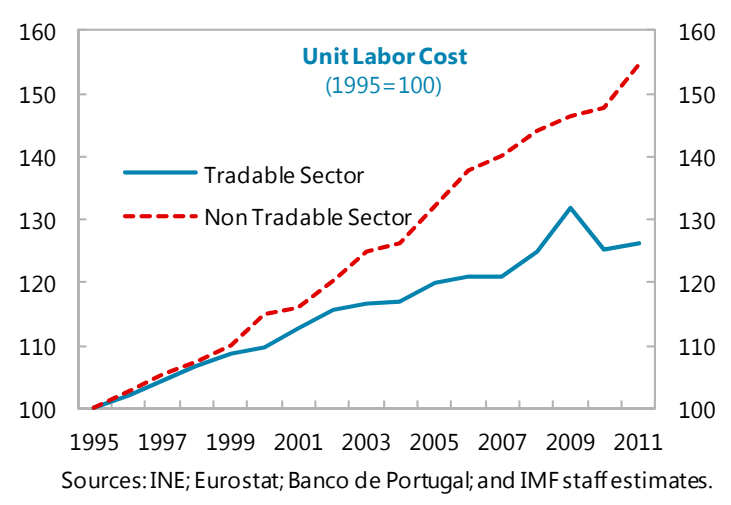

${ }^{1}$ See also SI Chapter II: "Portugal's Competitiveness."

${ }^{2}$ See Lipschitz and McDonald (1992), Empirica, Vol. 19, No. 1. 


\section{Box 2. How Fast Can Portugal Grow ${ }^{1}$}

In the run-up to and after euro adoption, productivity growth in Portugal has lagged that of peers. Real GDP grew by over 2 percent on average during 1992-2007, but this reflected mainly an expansion of the labor force and the capital stock. Total factor productivity (TFP) growth was negligible, compared to an annual average of about $1 / 2$ percent for EU's best performing countries (EU-9) and close to 1 percent on the U.S. Even when controlling for the difference in human capitalwhich explains about one third of the difference in labor productivity with the more advanced OECD countries-TFP growth was much lower than that of the stronger performers; and relative TFP (also sometimes referred to as technical efficiency) actually declined over this period.

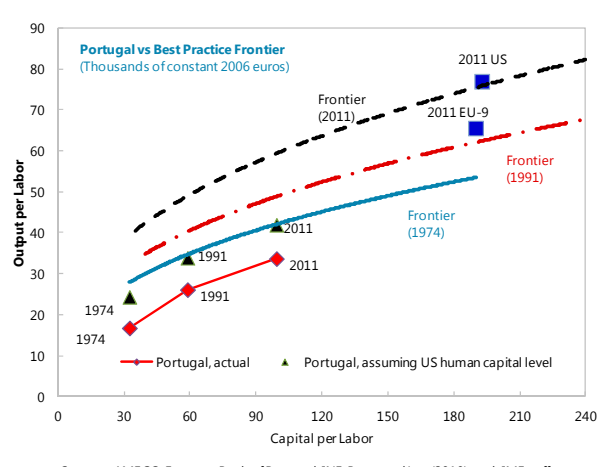

Sources: AMECO; Eurostat, Bank of Portugal; INE; Barro and Lee (2010); and IMFstaff

The human capital and structural policy gaps appear to play a critical role in explaining the lack of convergence. TFP convergence tends to be faster when human capital is higher and when market institutions are more developed. In the case of Portugal, empirical studies show that the gap in these areas could account for most of the GDP per capita gap relative to the peers. In the run-up to and after euro adoption, the lack of highquality human capital and competition seems to have hindered the adoption of information technology and facilitated the misallocation of capital. Much of the capital inflows during this period was in the form of debt-with over-leverage hindering productivity-and directed towards the non-tradable activities, where productivity growth was lower. After euro adoption, the economy relied on domestic demand, but with a declining contribution of investment to growth; relative prices, including nominal unit labor costs, diverged from northern European countries, further hindering

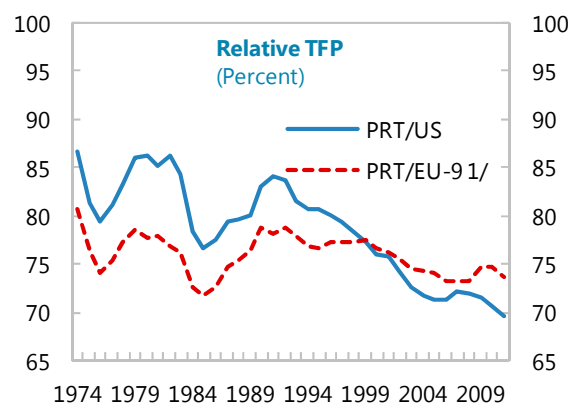

Source: Staff calculations.

1/ Includes Austria, Belgium, Denmark, Finland, France, Germany, Netherlands, Sweden, and UK. competitiveness and productivity and leading to higher structural unemployment.

Looking ahead, sustained structural reforms should facilitate productivity growth. Reaching the 2 percent growth mark does not seem out of reach over the long term, as staff analysis suggests that a strong and sustained reform effort could raise annual TFP growth to about 1 percent. Labor market reforms would help reduce structural unemployment. A stronger competition framework and product market reforms would reduce price markup of nontradables, facilitate a better

\begin{tabular}{|c|c|c|c|c|c|}
\hline & \multirow[b]{2}{*}{$\begin{array}{c}\text { GDP growth } \\
\text { (percent) }\end{array}$} & \multicolumn{4}{|c|}{ Contribution to GDP growth (percentage point) } \\
\hline & & Capital & Labor & $\begin{array}{l}\text { Human } \\
\text { capital }\end{array}$ & $\begin{array}{l}\text { Total factor } \\
\text { productivity }\end{array}$ \\
\hline 1992-07 & 2.2 & 1.3 & 0.4 & 0.4 & 0.0 \\
\hline 2018-32 (pess imistic) & 0.6 & 0.3 & -0.1 & 0.4 & 0.0 \\
\hline 2018-32 (moderately pessimistic) & 1.2 & 0.4 & -0.1 & 0.4 & 0.5 \\
\hline 2018-32 (baseline) & 1.9 & 0.5 & 0.0 & 0.4 & 1.0 \\
\hline 2018-32 (optimistic) & 2.7 & 0.7 & 0.1 & 0.4 & 1.5 \\
\hline
\end{tabular}
allocation of capital, and boost investment and productivity. Although reforms in the education sector take a long time to significantly boost human capital, efforts in this area could also help growth prospects. The challenge is rather that reaching the 2-percent growth mark in the medium-term implies both a rapid turnaround in underlying TFP growth and a recovery (even if modest) in investment, despite strong headwinds from public and private sector deleveraging.

${ }^{1}$ See SI Chapter I: "How Fast Can Portugal Grow?" 
Box 3. Growth-Friendly, Equitable, and Sustainable Fiscal Reform in Portugal ${ }^{1}$

Portugal's public finances need to be put in a long-term sustainable footing. The sharp increase in public spending over 2000-10, mainly fueled by the expansion of social protection, was not accompanied by sustainable sources of revenue or output growth. As a result, imbalances in the public accounts accumulated throughout the past decade, often masked by the adoption of temporary measures. Moreover, there was aggressive off-budget spending leading to a buildup of substantial contingent liabilities. The effect has been to leave the sovereign as one of the most indebted countries in Europe, with public debt increasing by 55 percentage points of GDP since 2006.

The ongoing consolidation has started to address these imbalances but further fiscal adjustment is needed, and there is broad political consensus that this should be focused on the spending side. Close to two-thirds of public spending falls on pensions and the public sector wage bill, making cuts in these areas unavoidable.

The need for pension reform means that care has to be taken to avoid the adjustment falls on socially vulnerable groups. But many aspects of the current pension system are regressive, suggesting that the there is scope to enhance the targeting of social protection while protecting those at risk of poverty. For example, each percentage point of pension spending reduces old-age poverty by only about 5 percentage points, below the European average of 7 percentage points. Part of the reason for this is that 40 percent of old age pension spending goes to the top 10 percent of the income distribution in the whole population. The reform options include: aligning benefits from specialized pension regimes with the general public pension system; equalizing eligibility conditions for all who retire starting in 2014; eliminating grandfathering for those who are not yet retired; and increasing the statutory retirement age (currently at age 65).
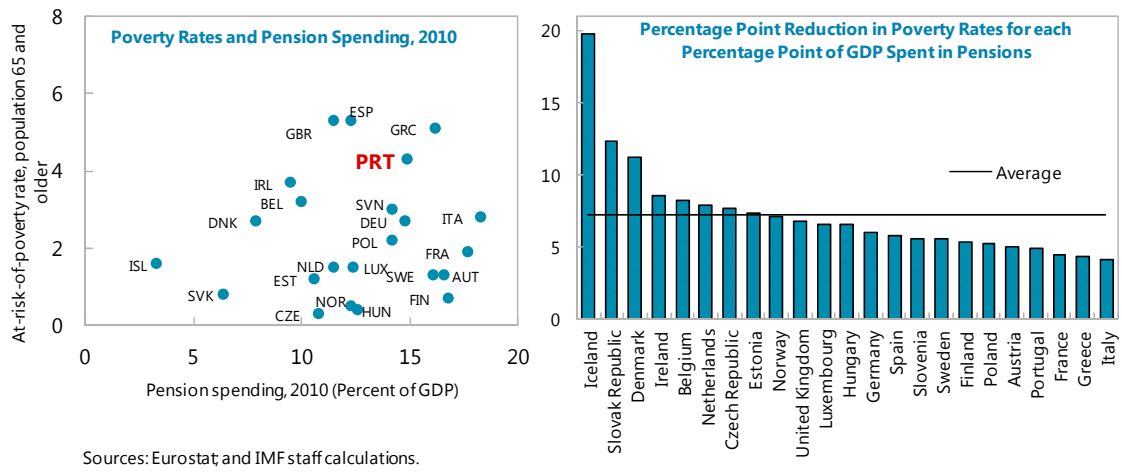

On the wage bill front, the main challenge is with excess employment in some areas. There has been some progress in reducing the wage bill, but studies show that the wage premium for public employees is about 10 percent above the average European country. This wage premium is the highest in the education sector, which also employs more people than peer countries but with poor educational outcomes.

Increasing the civil service working hours is another reform option, with public sector employees working 35 hours per week, the lowest level among OECD countries.

Revenue challenges are related to the composition of the tax burden composition. The tax system could be made more growth-friendly through: lowering the taxation on capital and increasing that on consumption; and streamlining of sizable untargeted tax expenditures, generating space for rate reductions in the corporate and personal income taxes. Simplifying the tax system and improving tax compliance would ensure a fair playing field for doing business in Portugal.

${ }^{1}$ See SI Chapter IV: "Growth-Friendly, Equitable, and Sustainable Fiscal Reform in Portugal." 


\section{Box 4. Portugal's Corporate Leverage in Perspective ${ }^{1}$}

Portugal has entered the crisis with a highly leveraged corporate sector, fuelled by low lending rates and easy access to bank credit since Euro adoption. The current corporate debt overhang of Portuguese firms is well above peer-countries levels in the Euro area and the high-debt thresholds identified in the literature, while comparable to past crisis episodes with corporate deleveraging.
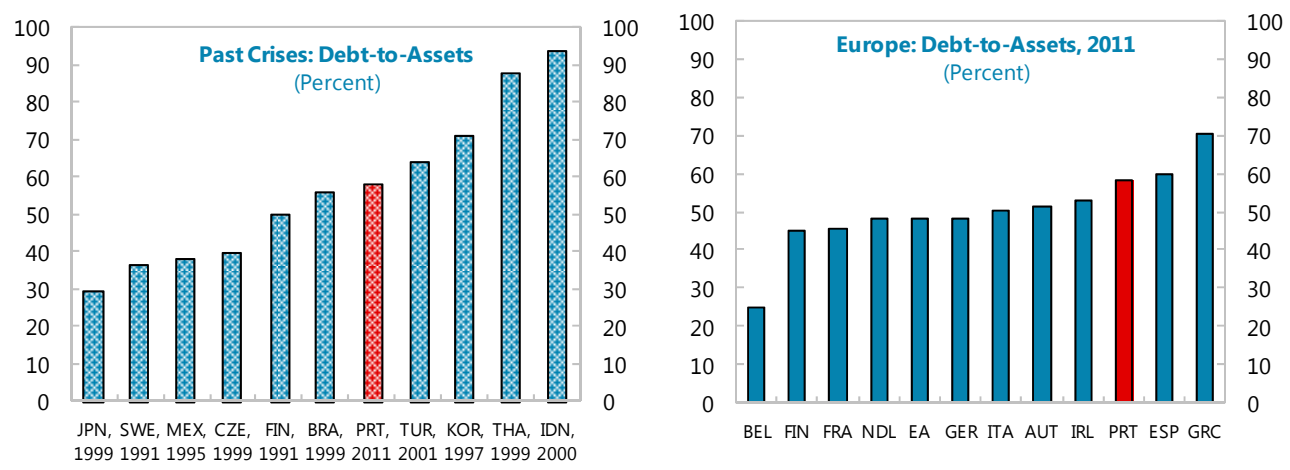

Sources: Claessens (2005) for past episodes; Eurostat and INE for Portugal and rest of Europe in 2011.

During the leveraging up process, a substantial portion of debt went into the balance sheets of firms in nontradable sectors, including the large share of small and medium enterprises. With the crisis, the risk of corporate default, especially in these segments, has increased significantly. Although banks appear adequately provisioned, also thanks to ongoing supervisory efforts, the high sensitivity of firms' balance sheets to macrofinancial shocks calls for constant monitoring of developments in the sector.

The elevated corporate debt overhang has weighted on the country's investment and growth paths in the run-up to the crisis. Reducing debt to more sustainable levels is needed to allow resources to be redirected to the most productive and innovative segments of the economy and secure the long-term viability of the private sector. However, based on past experiences, this process is expected to be protracted and entail sizable macro-financial costs upfront. Its impact on the Portuguese economy is already visible and could deepen further, especially given limited fiscal space and weak external demand in the Euro area. Although the migration of losses from private to public balance sheets has been contained so far, past crisis experiences provide evidence that risks can increase going forward.
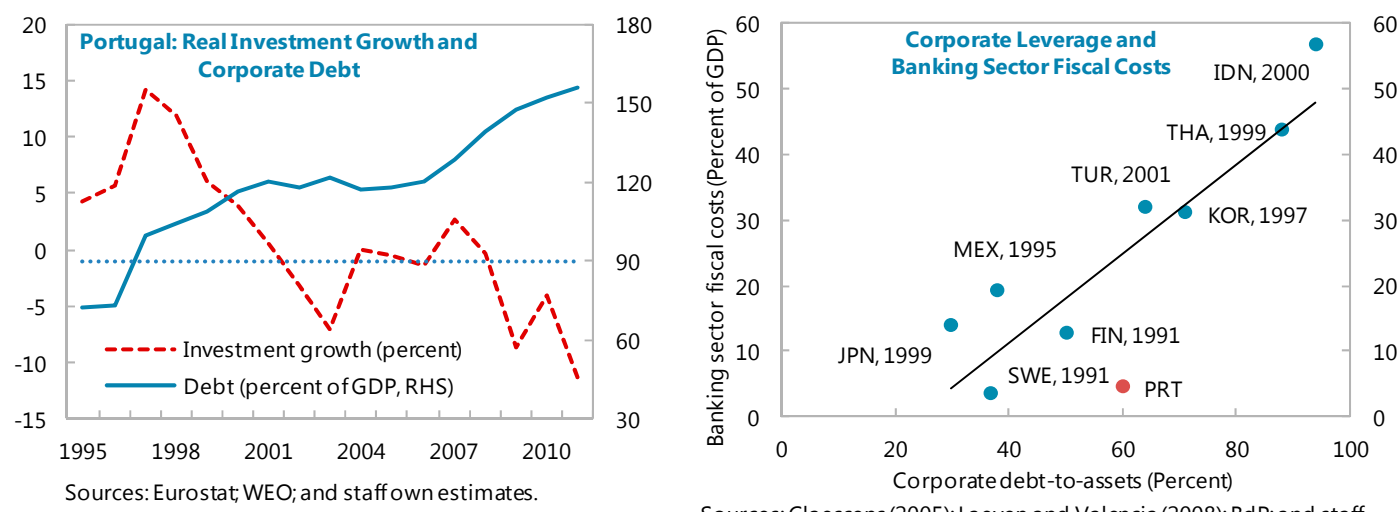

Sources: Claessens (2005); Laeven and Valencia (2008); BdP; and staff own estimates.

${ }^{1}$ See SI Chapter III on "Portugal's Corporate (De) Leveraging." 


\begin{tabular}{|c|c|c|c|c|c|c|c|c|c|}
\hline \multicolumn{10}{|c|}{$\begin{array}{c}\text { Table 1. Portugal: Selected Economic Indicators - Program Baseline } \\
\text { (Year-on-year percent change, unless otherwise indicated) }\end{array}$} \\
\hline & \multirow[b]{2}{*}{2009} & \multirow[b]{2}{*}{2010} & \multirow[b]{2}{*}{2011} & \multicolumn{4}{|c|}{ Projections } & \multirow[b]{2}{*}{2016} & \multirow[b]{2}{*}{2017} \\
\hline & & & & 2012 & 2013 & 2014 & 2015 & & \\
\hline Real GDP & -2.9 & 1.4 & -1.6 & -3.0 & -1.0 & 0.8 & 1.8 & 1.8 & 1.8 \\
\hline Total domestic demand & -3.3 & 0.8 & -5.7 & -6.5 & -2.9 & 0.3 & 1.4 & 1.4 & 1.4 \\
\hline Private consumption & -2.3 & 2.1 & -4.0 & -5.7 & -2.2 & 0.4 & 1.0 & 1.0 & 0.8 \\
\hline Public consumption & 4.7 & 0.9 & -3.8 & -3.5 & -3.2 & -2.0 & 0.4 & 0.6 & 2.0 \\
\hline Gross fixed investment & -8.6 & -4.1 & -11.3 & -13.7 & -5.5 & 3.0 & 4.0 & 4.0 & 3.0 \\
\hline Private & -10.2 & -8.2 & -7.0 & -12.0 & -4.7 & 4.2 & 5.2 & 4.9 & 3.1 \\
\hline Government & 2.0 & 19.5 & -30.3 & -23.7 & -11.0 & -6.5 & -5.5 & -3.8 & 1.8 \\
\hline Exports & -10.9 & 8.8 & 7.5 & 4.6 & 2.9 & 5.0 & 5.3 & 5.2 & 5.2 \\
\hline Imports & -10.0 & 5.4 & -5.3 & -5.9 & -2.2 & 3.8 & 4.5 & 4.5 & 4.5 \\
\hline \multicolumn{10}{|l|}{ Contribution to Growth } \\
\hline Total domestic demand & -3.6 & 0.9 & -6.2 & -6.8 & -2.9 & 0.3 & 1.4 & 1.4 & 1.4 \\
\hline Private consumption & -1.5 & 1.4 & -2.7 & -3.7 & -1.4 & 0.2 & 0.7 & 0.6 & 0.5 \\
\hline Public consumption & 1.0 & 0.2 & -0.8 & -0.8 & -0.7 & -0.4 & 0.1 & 0.1 & 0.4 \\
\hline Gross fixed investment & -1.9 & -0.9 & -2.2 & -2.4 & -0.9 & 0.4 & 0.6 & 0.6 & 0.5 \\
\hline Foreign balance & 0.6 & 0.5 & 4.5 & 3.9 & 1.9 & 0.5 & 0.4 & 0.4 & 0.4 \\
\hline \multicolumn{10}{|l|}{ Savings-investment balance (percent of GDP) } \\
\hline Gross national savings & 9.4 & 9.9 & 10.9 & 13.3 & 13.8 & 14.5 & 15.4 & 16.3 & 16.5 \\
\hline Private & 16.4 & 16.8 & 15.7 & 16.3 & 16.5 & 15.3 & 15.8 & 16.5 & 16.8 \\
\hline Public & -6.9 & -6.9 & -4.9 & -3.0 & -2.7 & -0.8 & -0.4 & -0.3 & -0.3 \\
\hline Gross domestic investment & 20.2 & 19.6 & 17.5 & 15.8 & 14.9 & 15.5 & 15.9 & 16.2 & 16.4 \\
\hline Private & 17.2 & 16.0 & 15.0 & 13.8 & 13.2 & 13.9 & 14.3 & 14.7 & 14.9 \\
\hline Public & 3.0 & 3.6 & 2.5 & 2.0 & 1.8 & 1.7 & 1.5 & 1.5 & 1.5 \\
\hline \multicolumn{10}{|l|}{ Resource utilization } \\
\hline Potential GDP & -0.1 & 0.1 & -0.3 & -0.6 & -0.4 & -0.1 & -0.1 & 0.9 & 0.9 \\
\hline Output Gap (\% of potential) & -1.5 & -0.3 & -1.6 & -3.9 & -4.5 & -3.6 & -1.7 & -0.8 & 0.0 \\
\hline Employment & -2.6 & -1.5 & -1.5 & -3.9 & -1.6 & 0.4 & 0.6 & 0.4 & 0.4 \\
\hline Unemployment rate (\%) $1 /$ & 9.5 & 10.8 & 12.7 & 15.5 & 16.4 & 15.9 & 15.3 & 14.8 & 14.3 \\
\hline \multicolumn{10}{|l|}{ Prices } \\
\hline GDP deflator & 0.9 & 1.1 & 0.6 & 0.3 & 1.3 & 1.1 & 1.4 & 1.5 & 1.5 \\
\hline Consumer prices (harmonized index) & -0.9 & 1.4 & 3.6 & 2.8 & 0.8 & 1.2 & 1.3 & 1.5 & 1.5 \\
\hline Compensation per worker (whole economy) & 2.8 & 1.4 & -0.8 & -3.0 & 1.5 & 0.4 & 0.8 & 1.0 & 1.0 \\
\hline Labor productivity & -0.3 & 3.0 & -0.1 & 0.9 & 0.5 & 0.4 & 1.2 & 1.4 & 1.4 \\
\hline Unit labor costs (whole economy) & 3.2 & -1.6 & -0.7 & -3.9 & 1.0 & 0.0 & -0.4 & -0.4 & -0.4 \\
\hline \multicolumn{10}{|l|}{ Money and credit (end of period, percent change) } \\
\hline Private sector credit & 3.4 & -0.3 & -1.5 & -5.1 & -4.3 & -1.9 & -0.2 & 0.8 & 2.1 \\
\hline Broad money & -3.3 & -1.3 & -1.3 & -1.2 & 0.3 & 2.0 & 3.2 & 3.3 & 3.3 \\
\hline \multicolumn{10}{|l|}{ Interest rates (percent) } \\
\hline 6-month interbank rate & 1.7 & 0.8 & 1.4 & 0.6 & 0.2 & 0.5 & 0.9 & 1.4 & 1.9 \\
\hline Government bond rate, 10-year & 4.2 & 5.4 & 10.2 & 11.5 & 7.9 & 4.7 & 4.4 & 4.6 & 4.7 \\
\hline \multicolumn{10}{|l|}{ Fiscal indicators (percent of GDP) } \\
\hline General government balance (percent of GDP) 2/ & -10.2 & -9.8 & -4.4 & -5.0 & -4.5 & -2.5 & -2.0 & -1.8 & -1.8 \\
\hline Primary government balance (percent of GDP) & -7.3 & -7.0 & -0.4 & -0.8 & -0.2 & 2.1 & 2.7 & 2.9 & 2.8 \\
\hline Structural balance & -9.2 & -9.1 & -6.6 & -4.2 & -2.4 & -0.9 & -1.2 & -1.4 & -1.8 \\
\hline Structural primary balance (percent of potential GDP) & -6.3 & -6.2 & -2.6 & -0.1 & 1.8 & 3.6 & 3.4 & 3.2 & 2.8 \\
\hline General government debt & 83.1 & 93.3 & 108.1 & 120.0 & 122.2 & 122.3 & 120.0 & 117.2 & 115.0 \\
\hline \multicolumn{10}{|l|}{ External sector (percent of GDP) } \\
\hline Trade balance (goods) & -10.6 & -10.5 & -7.7 & -4.7 & -3.3 & -2.9 & -2.7 & -2.5 & -2.4 \\
\hline Trade balance (G\&S) & -7.0 & -6.7 & -3.2 & 0.6 & 2.8 & 3.4 & 3.7 & 4.1 & 4.5 \\
\hline Current account balance & -10.9 & -10.0 & -6.5 & -2.5 & -1.1 & -1.0 & -0.5 & 0.1 & 0.2 \\
\hline Net international investment position & -110.6 & -107.2 & -103.8 & -106.7 & -106.1 & -103.7 & -99.6 & -95.0 & -90.5 \\
\hline REER based on ULC $(1999=100)$ & 109.7 & 108.1 & 106.9 & 100.9 & 101.4 & 101.2 & 100.3 & 99.3 & 98.4 \\
\hline (rate of growth) & 1.1 & -1.4 & -1.2 & -5.6 & 0.5 & -0.2 & -0.9 & -1.0 & -0.9 \\
\hline REER based on CPI $(1999=100)$ & 110.1 & 107.8 & 108.7 & 108.3 & 106.8 & 106.5 & 106.1 & 106.0 & 105.8 \\
\hline (rate of growth) & -0.5 & -2.1 & 0.8 & -0.4 & -1.3 & -0.3 & -0.4 & -0.1 & -0.2 \\
\hline Nominal GDP (billions of euro) & 168.5 & 172.7 & 170.9 & 166.3 & 166.8 & 170.0 & 175.4 & 181.2 & 187.2 \\
\hline $\begin{array}{l}\text { Sources: Bank of Portugal; Ministry of Finance; National Sta } \\
\text { 1/ The unemployment rate series contains a structural brea } \\
\text { 2/ EDP notification concept. }\end{array}$ & ); Eur & nd & $\mathrm{f}_{\mathrm{pr}}$ & & & & & & \\
\hline
\end{tabular}

\section{CInternational Monetary Fund. Not for Redistribution}




\begin{tabular}{|c|c|c|c|c|c|c|c|c|c|}
\hline \multicolumn{10}{|c|}{$\begin{array}{l}\text { Table 2a. Portugal: General Government Accounts 1/ } \\
\text { (Billions of euros) }\end{array}$} \\
\hline & \multirow[b]{2}{*}{2009} & \multirow[b]{2}{*}{2010} & \multirow[b]{2}{*}{2011} & \multicolumn{6}{|c|}{ Projections } \\
\hline & & & & $\begin{array}{l}2012 \\
\text { Fifth } \\
\text { Review }\end{array}$ & 2012 & 2013 & 2014 & 2015 & 2016 \\
\hline Revenue & 66.7 & 71.5 & 76.9 & 69.4 & 67.5 & 70.6 & 72.3 & 74.4 & 76.3 \\
\hline Taxes & 36.6 & 38.4 & 40.4 & 38.6 & 38.6 & 41.7 & 42.4 & 43.9 & 45.5 \\
\hline Taxes on production and imports & 21.5 & 23.2 & 23.4 & 22.8 & 23.0 & 22.9 & 23.3 & 24.2 & 25.1 \\
\hline Current taxes on income, wealth, etc. and capital taxes & 15.1 & 15.3 & 17.0 & 15.8 & 15.5 & 18.8 & 19.1 & 19.7 & 20.4 \\
\hline Current taxes on income, wealth, etc. & 15.1 & 15.2 & 17.0 & 15.8 & 15.5 & 18.8 & 19.1 & 19.7 & 20.4 \\
\hline Capital taxes & 0.0 & 0.1 & 0.0 & 0.0 & 0.0 & 0.0 & 0.0 & 0.0 & 0.0 \\
\hline Social contributions & 21.0 & 21.1 & 20.9 & 19.5 & 19.4 & 20.0 & 20.4 & 20.7 & 21.2 \\
\hline Grants and other revenue & 9.0 & 11.9 & 15.6 & 11.2 & 9.5 & 8.9 & 9.5 & 9.7 & 9.6 \\
\hline Property income & 1.3 & 1.2 & 1.1 & 1.2 & 1.0 & 1.1 & 1.1 & 1.1 & 1.1 \\
\hline Sales of goods and services & 4.1 & 4.1 & 4.4 & 4.9 & 4.7 & 5.0 & 5.1 & 5.2 & 5.1 \\
\hline Other current revenue & 2.4 & 2.1 & 2.5 & 2.7 & 1.7 & 1.8 & 1.8 & 1.9 & 1.8 \\
\hline Capital transfers and investment grants & 1.2 & 4.6 & 7.6 & 2.5 & 2.1 & 1.1 & 1.5 & 1.5 & 1.5 \\
\hline of which: Pension funds transfer & 0.0 & 2.8 & 6.0 & 0.0 & 0.0 & 0.0 & 0.0 & 0.0 & 0.0 \\
\hline Expenditure 2/ & 83.8 & 88.5 & 84.4 & 77.7 & 75.8 & 78.2 & 76.6 & 77.8 & 79.5 \\
\hline Expense & 82.2 & 85.8 & 83.8 & 78.3 & 76.4 & 79.3 & 78.0 & 79.5 & 81.4 \\
\hline Compensation of employees & 21.4 & 21.1 & 19.4 & 16.3 & 16.7 & 17.2 & 16.4 & 16.6 & 16.8 \\
\hline Use of goods and services & 8.4 & 8.7 & 8.0 & 7.4 & 7.8 & 7.5 & 7.0 & 7.0 & 7.0 \\
\hline Consumption of fixed capital & 3.6 & 3.8 & 3.9 & 4.0 & 4.0 & 4.2 & 4.3 & 4.5 & 4.6 \\
\hline Interest (ESA95) & 4.8 & 5.0 & 6.9 & 7.5 & 7.0 & 7.3 & 7.9 & 8.2 & 8.4 \\
\hline Subsidies & 1.3 & 1.2 & 1.2 & 1.7 & 1.3 & 1.2 & 0.8 & 0.8 & 1.0 \\
\hline Social benefits & 37.0 & 37.8 & 37.6 & 36.8 & 36.9 & 37.6 & 37.4 & 38.2 & 39.2 \\
\hline Grants and other expense & 5.7 & 8.2 & 6.8 & 4.6 & 2.8 & 4.3 & 4.2 & 4.3 & 4.4 \\
\hline Other current expense & 4.3 & 4.9 & 4.4 & 4.0 & 3.1 & 3.7 & 3.4 & 3.5 & 3.6 \\
\hline Capital transfers & 1.4 & 3.3 & 2.4 & 0.6 & -0.3 & 0.6 & 0.8 & 0.8 & 0.8 \\
\hline Net acquisition of nonfinancial assets & 1.7 & 2.7 & 0.5 & -0.6 & -0.6 & -1.1 & -1.4 & -1.7 & -1.9 \\
\hline Gross fixed capital formation & 5.2 & 6.5 & 4.4 & 3.4 & 3.4 & 3.1 & 2.9 & 2.8 & 2.7 \\
\hline (-) Consumption of fixed capital & -3.6 & -3.8 & -3.9 & -4.0 & -4.0 & -4.2 & -4.3 & -4.5 & -4.6 \\
\hline Acquisitions less disposals of other nonfinancial assets & 0.0 & 0.0 & 0.0 & 0.0 & 0.0 & 0.0 & 0.0 & 0.0 & 0.0 \\
\hline Gross Operating Balance & -11.9 & -10.5 & -3.1 & -4.9 & -4.9 & -4.5 & -1.4 & -0.7 & -0.5 \\
\hline Net lending $(+) /$ borrowing (-) (ESA95) & -17.1 & -17.0 & -7.5 & -8.3 & -8.3 & -7.5 & -4.3 & -3.5 & -3.2 \\
\hline Net lending $(+) /$ borrowing $(-)$ (EDP notification) & -17.1 & -17.0 & -7.5 & -8.3 & -8.3 & -7.5 & -4.3 & -3.5 & -3.2 \\
\hline Net acquisition of financial assets & 1.1 & 4.9 & 14.8 & $\ldots$ & $\ldots$ & $\ldots$ & $\ldots$ & $\ldots$ & $\ldots$ \\
\hline Monetary gold and SDRs & 0.0 & 0.0 & 0.0 & $\ldots$ & $\ldots$ & $\ldots$ & $\ldots$ & $\ldots$ & $\ldots$ \\
\hline Currency and deposits & -0.5 & 0.7 & 10.2 & $\ldots$ & $\ldots$ & $\ldots$ & $\ldots$ & $\ldots$ & $\ldots$ \\
\hline Debt securities & 0.4 & -0.1 & 0.4 & $\ldots$ & $\ldots$ & $\ldots$ & $\ldots$ & $\ldots$ & $\ldots$ \\
\hline Loans & -0.2 & 1.3 & 0.9 & $\ldots$ & $\ldots$ & $\ldots$ & $\ldots$ & $\ldots$ & $\ldots$ \\
\hline Equity and investment fund shares & 1.0 & 1.6 & -0.3 & $\ldots$ & $\ldots$ & $\ldots$ & $\ldots$ & $\ldots$ & $\ldots$ \\
\hline Insurance, pensions, and standardized guarantee schemes & 0.0 & 0.0 & 0.0 & $\ldots$ & $\ldots$ & $\ldots$ & $\ldots$ & $\ldots$ & $\ldots$ \\
\hline Financial derivatives and employee stock options & -0.1 & -0.4 & -0.2 & $\ldots$ & $\ldots$ & $\ldots$ & $\ldots$ & $\ldots$ & $\ldots$ \\
\hline Other accounts receivable & 0.4 & 1.8 & 3.9 & $\ldots$ & $\ldots$ & $\ldots$ & $\ldots$ & $\ldots$ & $\ldots$ \\
\hline Net incurrence of liabilities & 18.2 & 21.9 & 22.4 & $\ldots$ & $\ldots$ & $\ldots$ & $\ldots$ & $\ldots$ & $\ldots$ \\
\hline SDRs & 0.0 & 0.0 & 0.0 & $\ldots$ & $\ldots$ & $\ldots$ & $\ldots$ & $\ldots$ & $\ldots$ \\
\hline Currency and deposits & -0.5 & -0.8 & -3.1 & $\ldots$ & $\ldots$ & $\ldots$ & $\ldots$ & $\ldots$ & $\ldots$ \\
\hline Debt securities & 16.2 & 17.8 & -11.2 & $\ldots$ & $\ldots$ & $\ldots$ & $\ldots$ & $\ldots$ & $\ldots$ \\
\hline Loans & 1.6 & 3.6 & 35.8 & & $\ldots$ & $\ldots$ & & $\ldots$ & $\ldots$ \\
\hline Equity and investment fund shares & 0.0 & 0.0 & 0.0 & $\ldots$ & $\ldots$ & $\ldots$ & $\ldots$ & $\ldots$ & $\ldots$ \\
\hline Insurance, pensions, and standardized guarantee schemes & 0.0 & 0.0 & 0.0 & $\ldots$ & $\ldots$ & $\ldots$ & $\ldots$ & $\ldots$ & $\ldots$ \\
\hline Financial derivatives and employee stock options & 0.0 & 0.0 & 0.3 & $\ldots$ & $\ldots$ & $\ldots$ & $\ldots$ & $\ldots$ & $\ldots$ \\
\hline Other accounts payable & 0.9 & 1.3 & 0.6 & $\ldots$ & $\ldots$ & $\ldots$ & $\ldots$ & $\ldots$ & $\ldots$ \\
\hline \multicolumn{10}{|l|}{ Memorandum items: } \\
\hline Primary balance & -12.3 & -12.0 & -0.6 & -0.8 & -1.3 & -0.3 & 3.6 & 4.7 & 5.2 \\
\hline Interest (EDP notification) & 4.8 & 4.9 & 6.9 & 7.5 & 7.0 & 7.3 & 7.9 & 8.2 & 8.4 \\
\hline Debt at face value (EDP notification) & 139.9 & 161.1 & 184.7 & 198.1 & 199.7 & 203.8 & 207.9 & 210.6 & 212.4 \\
\hline Nominal GDP & 168.5 & 172.7 & 170.9 & 166.3 & 166.3 & 166.8 & 170.0 & 175.4 & 181.2 \\
\hline
\end{tabular}




\begin{tabular}{|c|c|c|c|c|c|c|c|c|c|}
\hline \multicolumn{10}{|c|}{$\begin{array}{c}\text { Table 2b. Portugal: General Government Accounts 1/ } \\
\text { (Percent of GDP) }\end{array}$} \\
\hline & \multirow[b]{2}{*}{2009} & \multirow[b]{2}{*}{2010} & \multirow[b]{2}{*}{2011} & \multicolumn{6}{|c|}{ Projections } \\
\hline & & & & $\begin{array}{l}2012 \\
\text { Fifth } \\
\text { Review }\end{array}$ & 2012 & 2013 & 2014 & 2015 & 2016 \\
\hline Revenue & 39.6 & 41.4 & 45.0 & 41.7 & 40.6 & 42.3 & 42.5 & 42.4 & 42.1 \\
\hline Taxes & 21.7 & 22.3 & 23.6 & 23.2 & 23.2 & 25.0 & 24.9 & 25.0 & 25.1 \\
\hline Taxes on production and imports & 12.8 & 13.4 & 13.7 & 13.7 & 13.9 & 13.7 & 13.7 & 13.8 & 13.9 \\
\hline Current taxes on income, wealth, etc. and capital taxes & 9.0 & 8.8 & 9.9 & 9.5 & 9.3 & 11.3 & 11.2 & 11.3 & 11.3 \\
\hline Social contributions & 12.5 & 12.2 & 12.2 & 11.7 & 11.7 & 12.0 & 12.0 & 11.8 & 11.7 \\
\hline Grants and other revenue & 5.4 & 6.9 & 9.1 & 6.8 & 5.7 & 5.4 & 5.6 & 5.5 & 5.3 \\
\hline Property income & 0.8 & 0.7 & 0.6 & 0.7 & 0.6 & 0.6 & 0.6 & 0.6 & 0.6 \\
\hline Sales of goods and services & 2.4 & 2.4 & 2.6 & 2.9 & 2.8 & 3.0 & 3.0 & 3.0 & 2.8 \\
\hline Other current revenue & 1.4 & 1.2 & 1.5 & 1.6 & 1.0 & 1.1 & 1.1 & 1.1 & 1.0 \\
\hline Capital transfers and investment grants & 0.7 & 2.6 & 4.4 & 1.5 & 1.3 & 0.6 & 0.9 & 0.9 & 0.9 \\
\hline of which: Pension funds transfer & 0.0 & 1.6 & 3.5 & 0.0 & 0.0 & 0.0 & 0.0 & 0.0 & 0.0 \\
\hline Expenditure 2/ & 49.8 & 51.3 & 49.4 & 46.7 & 45.6 & 46.9 & 45.0 & 44.4 & 43.9 \\
\hline Expense & 48.8 & 49.7 & 49.1 & 47.1 & 45.9 & 47.5 & 45.9 & 45.3 & 44.9 \\
\hline Compensation of employees & 12.7 & 12.2 & 11.4 & 9.8 & 10.0 & 10.3 & 9.7 & 9.5 & 9.3 \\
\hline Use of goods and services & 5.0 & 5.1 & 4.7 & 4.5 & 4.7 & 4.5 & 4.1 & 4.0 & 3.9 \\
\hline Consumption of fixed capital & 2.1 & 2.2 & 2.3 & 2.4 & 2.4 & 2.5 & 2.5 & 2.5 & 2.5 \\
\hline Interest (ESA95) & 2.9 & 2.9 & 4.0 & 4.5 & 4.2 & 4.4 & 4.6 & 4.7 & 4.6 \\
\hline Subsidies & 0.8 & 0.7 & 0.7 & 1.0 & 0.8 & 0.7 & 0.5 & 0.5 & 0.6 \\
\hline Social benefits & 22.0 & 21.9 & 22.0 & 22.1 & 22.2 & 22.6 & 22.0 & 21.8 & 21.6 \\
\hline Grants and other expense & 3.4 & 4.7 & 4.0 & 2.8 & 1.7 & 2.6 & 2.5 & 2.4 & 2.4 \\
\hline Other current expense & 2.5 & 2.8 & 2.6 & 2.4 & 1.9 & 2.2 & 2.0 & 2.0 & 2.0 \\
\hline Capital transfers & 0.9 & 1.9 & 1.4 & 0.4 & -0.2 & 0.3 & 0.5 & 0.4 & 0.4 \\
\hline Net acquisition of nonfinancial assets & 1.0 & 1.6 & 0.3 & -0.4 & -0.4 & -0.7 & -0.8 & -1.0 & -1.1 \\
\hline Gross fixed capital formation & 3.1 & 3.7 & 2.6 & 2.0 & 2.0 & 1.8 & 1.7 & 1.6 & 1.5 \\
\hline (-) Consumption of fixed capital & -2.1 & -2.2 & -2.3 & -2.4 & -2.4 & -2.5 & -2.5 & -2.5 & -2.5 \\
\hline Acquisitions less disposals of other nonfinancial assets & 0.0 & 0.0 & 0.0 & 0.0 & 0.0 & 0.0 & 0.0 & 0.0 & 0.0 \\
\hline Gross Operating Balance & -7.1 & -6.1 & -1.8 & -3.0 & -3.0 & -2.7 & -0.8 & -0.4 & -0.3 \\
\hline Net lending (+)/borrowing (-) (ESA95) & -10.2 & -9.8 & -4.4 & -5.0 & -5.0 & -4.5 & -2.5 & -2.0 & -1.8 \\
\hline Net lending $(+) /$ borrowing $(-)$ (EDP notification) & -10.2 & -9.8 & -4.4 & -5.0 & -5.0 & -4.5 & -2.5 & -2.0 & -1.8 \\
\hline Net acquisition of financial assets & 0.6 & 2.8 & 8.7 & $\ldots$ & $\ldots$ & $\ldots$ & $\ldots$ & $\ldots$ & $\ldots$ \\
\hline Monetary gold and SDRs & 0.0 & 0.0 & 0.0 & $\ldots$ & $\ldots$ & $\ldots$ & $\ldots$ & $\ldots$ & $\ldots$ \\
\hline Currency and deposits & -0.3 & 0.4 & 6.0 & $\ldots$ & $\ldots$ & $\ldots$ & $\ldots$ & $\ldots$ & $\ldots$ \\
\hline Debt securities & 0.2 & 0.0 & 0.2 & & $\ldots$ & $\ldots$ & $\ldots$ & $\ldots$ & $\ldots$ \\
\hline Loans & -0.1 & 0.7 & 0.5 & $\ldots$ & $\ldots$ & $\ldots$ & $\ldots$ & $\ldots$ & $\ldots$ \\
\hline Equity and investment fund shares & 0.6 & 0.9 & -0.2 & $\ldots$ & $\ldots$ & $\ldots$ & $\ldots$ & $\ldots$ & $\ldots$ \\
\hline Insurance, pensions, and standardized guarantee schemes & 0.0 & 0.0 & 0.0 & & $\ldots$ & $\ldots$ & $\ldots$ & & \\
\hline Financial derivatives and employee stock options & -0.1 & -0.2 & -0.1 & $\ldots$ & $\ldots$ & $\ldots$ & $\ldots$ & $\ldots$ & $\ldots$ \\
\hline Other accounts receivable & 0.3 & 1.0 & 2.3 & $\ldots$ & $\ldots$ & $\ldots$ & $\ldots$ & $\ldots$ & $\ldots$ \\
\hline Net incurrence of liabilities & 10.8 & 12.7 & 13.1 & & $\ldots$ & $\ldots$ & $\ldots$ & & $\ldots$ \\
\hline SDRs & 0.0 & 0.0 & 0.0 & $\ldots$ & $\ldots$ & $\ldots$ & $\ldots$ & $\ldots$ & $\ldots$ \\
\hline Currency and deposits & -0.3 & -0.5 & -1.8 & $\ldots$ & $\ldots$ & $\ldots$ & $\ldots$ & $\ldots$ & $\ldots$ \\
\hline Debt securities & 9.6 & 10.3 & -6.5 & $\ldots$ & $\ldots$ & $\ldots$ & $\ldots$ & $\ldots$ & $\ldots$ \\
\hline Loans & 1.0 & 2.1 & 20.9 & $\ldots$ & $\ldots$ & $\ldots$ & $\ldots$ & $\ldots$ & $\ldots$ \\
\hline Equity and investment fund shares & 0.0 & 0.0 & 0.0 & $\ldots$ & $\ldots$ & $\ldots$ & $\ldots$ & $\ldots$ & $\ldots$ \\
\hline Insurance, pensions, and standardized guarantee schemes & 0.0 & 0.0 & 0.0 & $\ldots$ & $\ldots$ & $\ldots$ & $\ldots$ & $\ldots$ & $\ldots$ \\
\hline Financial derivatives and employee stock options & 0.0 & 0.0 & 0.2 & $\ldots$ & $\ldots$ & $\ldots$ & $\ldots$ & $\ldots$ & $\ldots$ \\
\hline Other accounts payable & 0.5 & 0.8 & 0.4 & $\ldots$ & $\cdots$ & $\cdots$ & $\cdots$ & $\cdots$ & $\cdots$ \\
\hline \multicolumn{10}{|l|}{ Memorandum items: } \\
\hline Primary balance & -7.3 & -7.0 & -0.4 & -0.5 & -0.8 & -0.2 & 2.1 & 2.7 & 2.9 \\
\hline Structural balance (Percent of potential GDP) & -9.2 & -9.1 & -6.6 & -4.1 & -4.2 & -2.4 & -0.9 & -1.2 & -1.4 \\
\hline Structural primary balance (Percent of potential GDP) & -6.3 & -6.2 & -2.6 & 0.3 & -0.1 & 1.8 & 3.6 & 3.4 & 3.2 \\
\hline Interest (EDP notification) & 2.8 & 2.9 & 4.0 & 4.5 & 4.2 & 4.4 & 4.6 & 4.7 & 4.6 \\
\hline Debt at face value (EDP notification) & 83.1 & 93.3 & 108.1 & 119.1 & 120.0 & 122.2 & 122.3 & 120.0 & 117.2 \\
\hline
\end{tabular}

\section{CInternational Monetary Fund. Not for Redistribution}


Table 3. Portugal: General Government Stock Positions

(Billions of Euros)

\begin{tabular}{lrrrr}
\hline & 2008 & 2009 & 2010 & 2011 \\
\hline Net financial worth & -93.1 & -108.7 & -110.0 & -92.6 \\
Financial assets & 45.7 & 48.6 & 58.4 & 74.1 \\
Monetary gold and SDRs & 0.0 & 0.0 & 0.0 & 0.0 \\
Currency and deposits & 7.3 & 6.8 & 7.7 & 18.0 \\
Debt securities & 1.5 & 1.9 & 1.8 & 2.2 \\
Loans & 3.0 & 2.8 & 4.1 & 5.0 \\
Equity and investment fund shares & 25.8 & 28.7 & 34.3 & 34.2 \\
Insurance, pensions, and standardized guarantee schemes & 0.0 & 0.0 & 0.0 & 0.0 \\
Financial derivatives and employee stock options & -0.1 & 0.0 & 0.1 & 0.4 \\
Other accounts receivable & 8.1 & 8.5 & 10.3 & 14.2 \\
Liabilities & & & \\
Special Drawing Rights (SDRs) & 138.8 & 157.2 & 168.3 & 166.7 \\
Currency and deposits & 0.0 & 0.0 & 0.0 & 0.0 \\
Debt securities & 19.5 & 18.9 & 18.1 & 15.0 \\
Loans & 98.1 & 114.3 & 120.4 & 85.1 \\
Equity and investment fund shares & 15.7 & 17.4 & 21.2 & 58.0 \\
Insurance, pensions, and standardized guarantee schemes & 0.0 & 0.0 & 0.0 & 0.0 \\
Financial derivatives and employee stock options & 0.0 & 0.0 & 0.0 & 0.0 \\
Other accounts payable & 0.0 & 0.0 & 0.0 & 0.9 \\
Memorandum items: & 5.6 & 6.5 & 8.5 & 7.8 \\
Gross debt (at market value) & & & & \\
Gross debt at face value & 138.8 & 157.2 & 168.3 & 165.8 \\
Gross debt at face value (EDP notification) & 128.7 & 146.5 & 169.7 & 192.5 \\
Other economic flows - financial assets & 123.1 & 139.9 & 161.1 & 184.7 \\
Other economic flows - liabilities & $\ldots$ & 1.8 & 4.9 & 0.9 \\
\hline Sources: Portuguese statistical authorities; and IMF staff calculations. & $\ldots$ & 0.3 & -10.8 & -24.0 \\
\hline
\end{tabular}




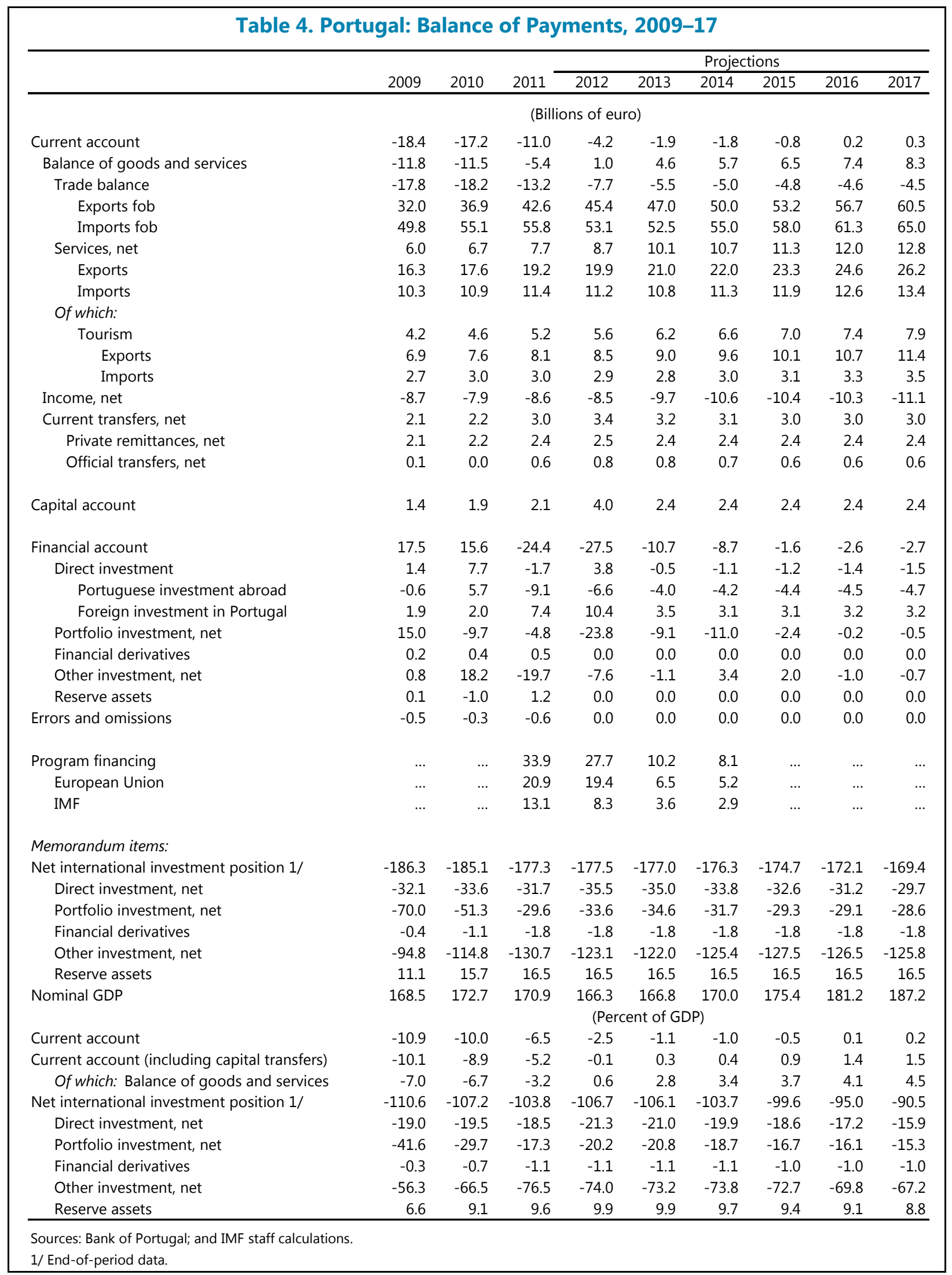




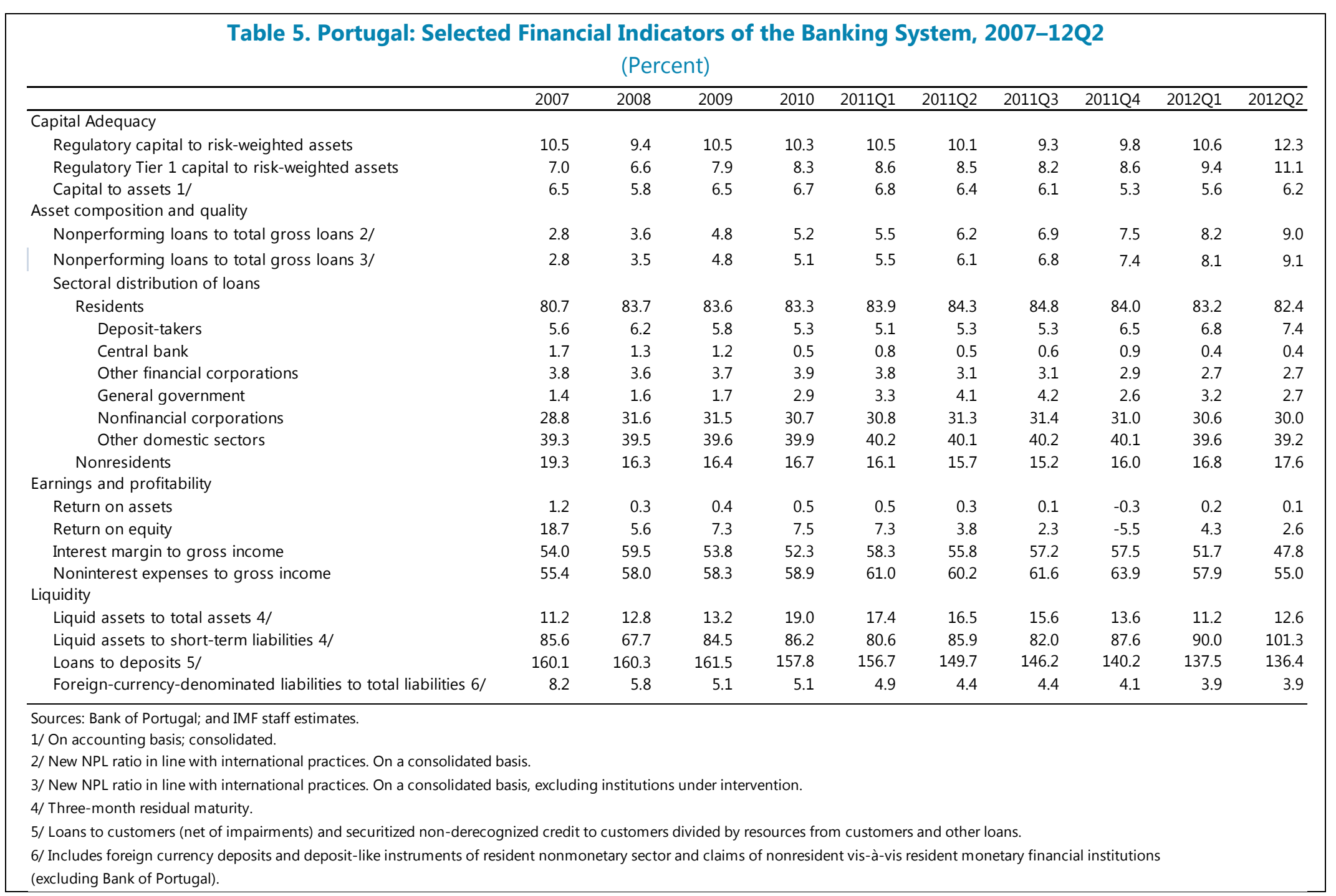

CInternational Monetary Fund. Not for Redistribution 
Table 6. Portugal: Monetary Survey, 2011-17

(Millions of euros, unless otherwise indicated; end of period)

\begin{tabular}{|c|c|c|c|c|c|c|c|}
\hline & & & & Project & & & \\
\hline & Dec-11 & Dec-12 & Dec-13 & Dec-14 & Dec-15 & Dec-16 & Dec-17 \\
\hline Aggregated Balance Sheet of Monetary Financial Institu & & & & & & & \\
\hline Assets & 472,496 & 458,580 & 447,203 & 445,577 & 444,623 & 450,842 & 459,290 \\
\hline Cash & 1,606 & 1,400 & 1,382 & 1,373 & 1,361 & 1,349 & 1,338 \\
\hline Claims on Bank of Portugal & 5,692 & 2,211 & 2,324 & 5,438 & 2,473 & 1,124 & 511 \\
\hline Claims on other FIs & 53,526 & 45,733 & 45,470 & 44,744 & 44,149 & 44,744 & 44,149 \\
\hline Claims on non MFIs & 307,347 & 300,330 & 285,944 & 279,028 & 278,155 & 281,536 & 287,489 \\
\hline General government & 32,309 & 39,411 & 36,172 & 34,112 & 33,693 & 34,995 & 35,709 \\
\hline Central government (excluding SOEs) & 19,544 & 28,101 & 24,700 & 22,087 & 21,205 & 22,459 & 23,231 \\
\hline loans & 467 & 1,273 & 1,273 & 1,193 & 1,114 & 1,034 & 954 \\
\hline securities & 19,078 & 26,828 & 23,427 & 20,894 & 20,091 & 21,425 & 22,277 \\
\hline Bonds & 10,307 & 15,997 & 14,608 & 13,323 & 13,560 & 14,894 & 15,746 \\
\hline Tbills & 8,770 & 10,831 & 8,819 & 7,571 & 6,531 & 6,531 & 6,531 \\
\hline Regional and local government (excl SOEs) & 6,408 & 5,854 & 6,042 & 6,042 & 6,042 & 6,042 & 6,042 \\
\hline SOES & 6,365 & 5,456 & 5,431 & 5,984 & 6,447 & 6,495 & 6,437 \\
\hline Private sector & 275,038 & 260,919 & 249,772 & 244,916 & 244,463 & 246,541 & 251,780 \\
\hline Claims on non-residents & 96,585 & 101,371 & 104,530 & 107,294 & 110,539 & 113,882 & 117,327 \\
\hline Other assets & 7,740 & 7,533 & 7,553 & 7,701 & 7,945 & 8,206 & 8,476 \\
\hline Liabilities & 472,496 & 458,580 & 447,203 & 445,577 & 444,623 & 450,842 & 459,290 \\
\hline Liabilities to Bank of Portugal & 46,928 & 59,782 & 54,568 & 51,557 & 34,426 & 24,310 & 15,723 \\
\hline Liabilities to other FIs & 60,888 & 54,913 & 54,102 & 54,174 & 54,522 & 57,468 & 58,971 \\
\hline Deposits of non MFIs & 176,290 & 171,984 & 172,575 & 179,138 & 185,637 & 192,374 & 199,357 \\
\hline General government & 12,279 & 8,672 & 1,172 & 1,172 & 1,172 & 1,172 & 1,172 \\
\hline Private sector & 164,011 & 163,312 & 171,403 & 177,966 & 184,465 & 191,202 & 198,185 \\
\hline Securities other than capital & 53,345 & 35,262 & 28,356 & 19,568 & 20,683 & 21,075 & 24,637 \\
\hline Liabilities to non-residents & 105,130 & 93,044 & 95,836 & 98,711 & 101,672 & 104,722 & 107,864 \\
\hline Other & $-10,690$ & $-12,730$ & $-12,832$ & $-11,548$ & $-10,495$ & $-10,840$ & $-11,196$ \\
\hline Capital and reserves & 40,606 & 56,324 & 54,599 & 53,977 & 58,178 & 61,734 & 63,933 \\
\hline Money and Credit & & & & & & & \\
\hline Broad Money (M3) & 172,547 & 170,390 & 170,842 & 174,180 & 179,714 & 185,609 & 191,717 \\
\hline Intermediate money (M2) & 169,872 & 165,332 & 165,770 & 169,009 & 174,379 & 180,098 & 186,025 \\
\hline Narrow money (M1) & 67,504 & 68,186 & 68,367 & 69,703 & 71,917 & 74,276 & 76,720 \\
\hline Private sector credit & 275,038 & 260,919 & 249,772 & 244,916 & 244,463 & 246,541 & 251,780 \\
\hline Public sector credit & 32,309 & 39,411 & 36,172 & 34,112 & 33,693 & 34,995 & 35,709 \\
\hline & & & (Percent & DP) & & & \\
\hline Broad Money & 101.0 & 102.4 & 102.4 & 102.4 & 102.4 & 102.4 & 102.4 \\
\hline Private sector credit & 160.9 & 156.9 & 149.8 & 144.0 & 139.3 & 136.1 & 134.5 \\
\hline Public sector credit & 18.9 & 23.7 & 21.7 & 20.1 & 19.2 & 19.3 & 19.1 \\
\hline & & & (Percentag & lange) & & & \\
\hline Broad Money & -1.3 & -1.2 & 0.3 & 2.0 & 3.2 & 3.3 & 3.3 \\
\hline Private sector credit & -1.5 & -5.1 & -4.3 & -1.9 & -0.2 & 0.8 & 2.1 \\
\hline Public sector credit & -4.5 & 22.0 & -8.2 & -5.7 & -1.2 & 3.9 & 2.0 \\
\hline Memo items: & & & & & & & \\
\hline ECB access (\% assets) & 9.9 & 13.0 & 12.2 & 11.6 & 7.7 & 5.4 & 3.4 \\
\hline Credit to deposits (\%) & 146.1 & 140.5 & 130.9 & 124.8 & 120.8 & 117.1 & 115.1 \\
\hline Loan to deposits (\%) $2 /$ & 140.9 & 141.5 & 137.5 & 132.0 & 128.7 & 125.4 & 124.0 \\
\hline Wholesale market funding (\% assets) $3 /$ & 29.5 & 24.0 & 23.6 & 22.2 & 23.1 & 23.4 & 24.3 \\
\hline
\end{tabular}

\section{CInternational Monetary Fund. Not for Redistribution}


Table 7. Portugal: External Debt Sustainability Framework, 2007-17

(Percent of GDP, unless otherwise indicated)

\begin{tabular}{|c|c|c|c|c|c|c|c|c|c|c|c|c|}
\hline & \multicolumn{5}{|c|}{ Actual } & \multicolumn{7}{|c|}{ Projections } \\
\hline & 2007 & 2008 & 2009 & 2010 & 2011 & 2012 & 2013 & 2014 & 2015 & 2016 & 2017 & \multirow{2}{*}{$\begin{array}{c}\text { Debt-stabilizing } \\
\text { non-interest } \\
\text { current account } 6 \\
-0.1\end{array}$} \\
\hline Baseline: External debt & 195.5 & 200.8 & 223.8 & 231.2 & 230.7 & 234.2 & 236.8 & 233.8 & 224.0 & 215.0 & 208.2 & \\
\hline Change in external debt & 9.0 & 5.3 & 23.0 & 7.4 & -0.5 & 3.5 & 2.5 & -2.9 & -9.8 & -9.0 & -6.8 & \\
\hline Identified external debt-creating flows $(4+8+9)$ & 2.6 & 5.1 & 13.3 & 0.0 & 12.6 & 10.2 & 5.1 & -0.1 & -3.3 & -3.6 & -3.5 & \\
\hline Current account deficit, excluding interest payments & 3.2 & 4.7 & 4.8 & 4.7 & -0.1 & -4.6 & -5.8 & -5.3 & -5.4 & -6.1 & -6.5 & \\
\hline Deficit in balance of goods and services & 7.5 & 9.5 & 7.0 & 6.7 & 3.2 & -0.6 & -2.8 & -3.4 & -3.7 & -4.1 & -4.5 & \\
\hline Exports & 32.8 & 33.2 & 28.7 & 31.5 & 36.1 & 39.3 & 40.7 & 42.4 & 43.6 & 44.9 & 46.3 & \\
\hline Imports & 40.3 & 42.7 & 35.7 & 38.2 & 39.3 & 38.7 & 38.0 & 39.0 & 39.9 & 40.8 & 41.9 & \\
\hline Net non-debt creating capital inflows (negative) & 1.8 & -4.5 & -1.8 & -4.6 & 3.8 & 0.7 & 1.5 & 0.7 & 0.2 & 0.2 & 0.3 & \\
\hline Automatic debt dynamics $1 /$ & -2.4 & 4.9 & 10.3 & -0.1 & 8.9 & 14.1 & 9.4 & 4.4 & 1.9 & 2.3 & 2.7 & \\
\hline Contribution from nominal interest rate & 6.9 & 7.9 & 6.1 & 5.3 & 6.5 & 7.1 & 7.0 & 6.4 & 6.0 & 6.2 & 6.4 & \\
\hline Contribution from real GDP growth & -4.2 & 0.0 & 6.0 & -3.1 & 3.8 & 7.0 & 2.5 & -2.0 & -4.1 & -3.9 & -3.7 & \\
\hline Contribution from price and exchange rate changes $2 /$ & -5.1 & -3.0 & -1.8 & -2.3 & -1.4 & $\ldots$ & $\ldots$ & $\ldots$ & $\ldots$ & $\ldots$ & $\ldots$ & \\
\hline Residual, incl. change in gross foreign assets (2-3) 3/ & 6.4 & 0.2 & 9.7 & 7.4 & -13.2 & -6.7 & -2.6 & -2.8 & -6.5 & -5.3 & -3.4 & \\
\hline External debt-to-exports ratio (in percent) & 596.5 & 605.2 & 780.1 & 733.1 & 638.7 & 596.7 & 581.1 & 552.0 & 513.9 & 479.3 & 449.5 & \\
\hline Gross external financing need (in billions of Euros) 4/ & & & & 187.0 & 210.8 & 180.7 & 173.7 & 180.7 & 181.6 & 159.6 & 152.1 & \\
\hline in percent of GDP & & & & 108.3 & 123.3 & 108.7 & 104.2 & 106.3 & 103.5 & 88.1 & 81.3 & \\
\hline Scenario with key variables at their historical averages 5 / & & & & & & 234.2 & 236.9 & 239.0 & 237.9 & 238.0 & 240.0 & -1.7 \\
\hline \multicolumn{13}{|l|}{ Key Macroeconomic Assumptions Underlying Baseline } \\
\hline Real GDP growth (in percent) & 2.4 & 0.0 & -2.9 & 1.4 & -1.6 & -3.0 & -1.0 & 0.8 & 1.8 & 1.8 & 1.8 & \\
\hline GDP deflator in Euros (change in percent) & 2.8 & 1.6 & 0.9 & 1.1 & 0.6 & 0.3 & 1.3 & 1.1 & 1.4 & 1.5 & 1.5 & \\
\hline Nominal external interest rate (in percent) & 3.9 & 4.1 & 3.0 & 2.4 & 2.8 & 3.0 & 3.0 & 2.7 & 2.6 & 2.8 & 3.1 & \\
\hline Growth of exports (Euros, in percent) & 9.9 & 2.8 & -15.3 & 12.7 & 13.3 & 5.8 & 4.1 & 6.0 & 6.2 & 6.3 & 6.6 & \\
\hline Growth of imports (Euros, in percent) & 6.7 & 7.8 & -18.1 & 9.6 & 1.9 & -4.2 & -1.5 & 4.7 & 5.4 & 5.6 & 6.1 & \\
\hline Current account balance, excluding interest payments & -3.2 & -4.7 & -4.8 & -4.7 & 0.1 & 4.6 & 5.8 & 5.3 & 5.4 & 6.1 & 6.5 & \\
\hline Net non-debt creating capital inflows & -1.8 & 4.5 & 1.8 & 4.6 & -3.8 & -0.7 & -1.5 & -0.7 & -0.2 & -0.2 & -0.3 & \\
\hline \multicolumn{13}{|c|}{$\begin{array}{l}\text { 1/ Derived as }[r-g-r(1+g)+\text { ea }(1+r)] /(1+g+r+g r) \text { times previous period debt stock, with } r=\text { nominal effective interest rate on external debt; } r=\text { change in domestic GDP deflator, } \\
g=\text { real } G D P \text { growth rate, } e=\text { nominal appreciation (increase in dollar value of domestic currency-not used here), and a }=\text { share of domestic-currency denominated debt in total external debt. } \\
2 / \text { The contribution from price and exchange rate changes is defined as }[-r(1+g)+e a(1+r)] /(1+g+r+g r) \text { times previous period debt stock. } r \text { increases with an } \\
\text { appreciating domestic currency }(e>0) \text { and rising inflation (based on GDP deflator). } \\
3 / \text { For projection, line includes the impact of price and exchange rate changes. } \\
\text { 4/ Defined as current account deficit, plus amortization on medium- and long-term debt, plus short-term debt at end of previous period. } \\
5 / \text { The key variables include real GDP growth; nominal interest rate; deflator growth; and both non-interest current account and non-debt inflows in percent of GDP. } \\
6 / \text { Long-run, constant balance that stabilizes the debt ratio assuming that key variables (real GDP growth, nominal interest rate, deflator growth, and non-debt inflows in percent of GDP) remain at their levels } \\
\text { of the last projection year. }\end{array}$} \\
\hline
\end{tabular}


Table 8. Portugal: Government Debt Sustainability Framework, 2008-30

(Percent of GDP, unless otherwise indicated)

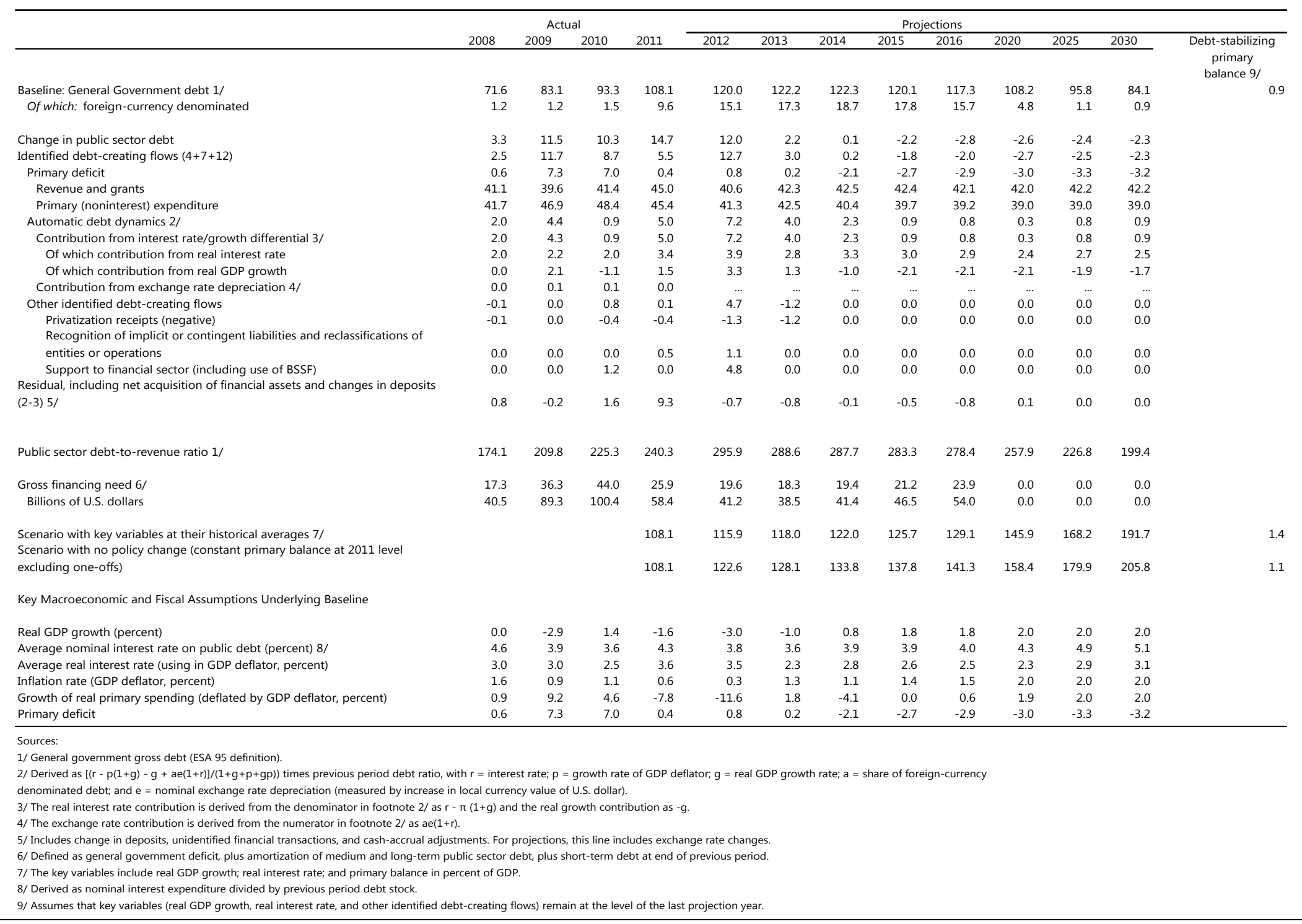


Figure 1. Portugal: High Frequency Indicators
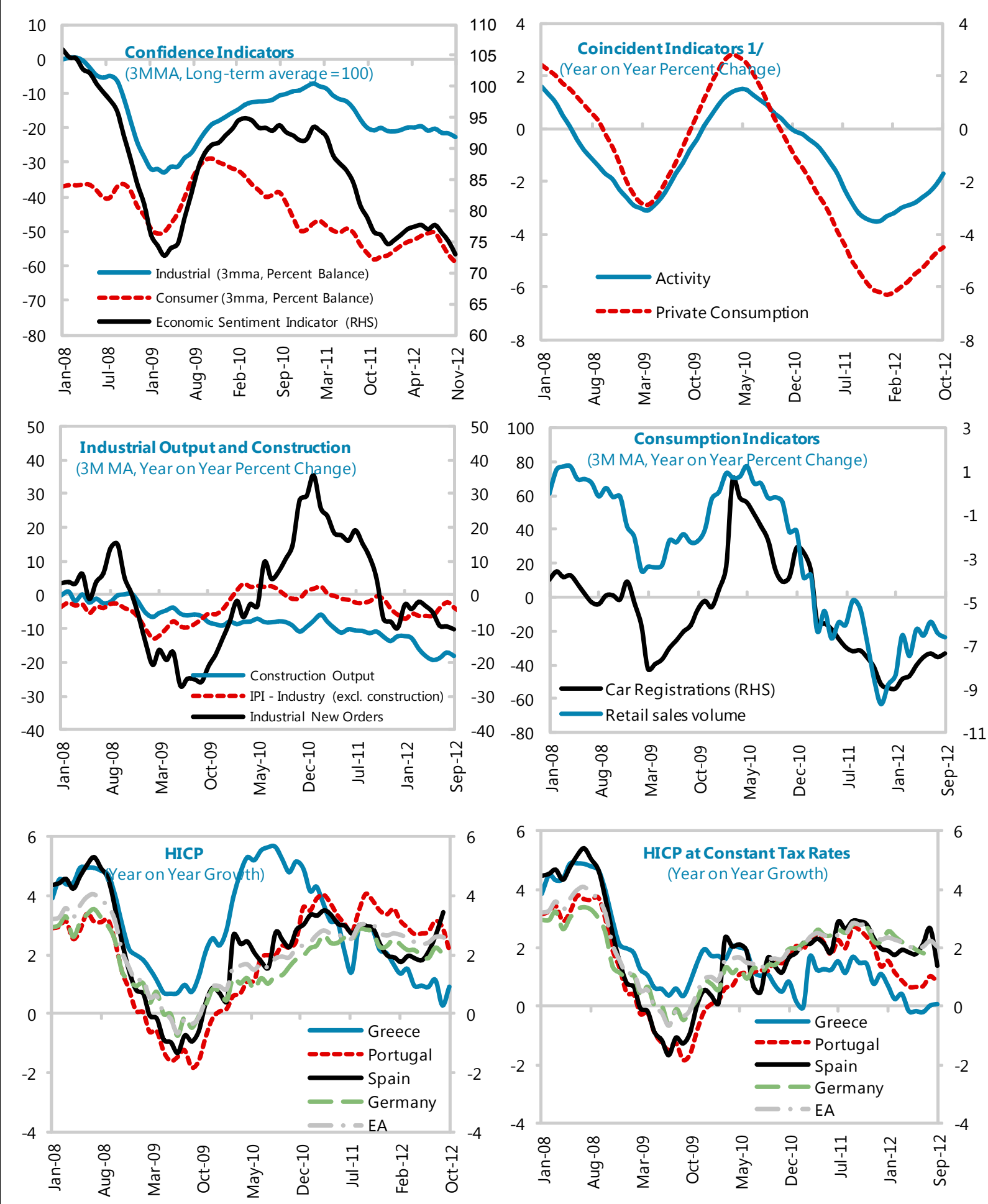

Source: Statistical Office of the European Communities; European Commission; Bank of Portugal; and Fund staff calculations. $1 /$ Calculated by the Bank of Portugal. 
Figure 2. Portugal: Labor Market Indicators

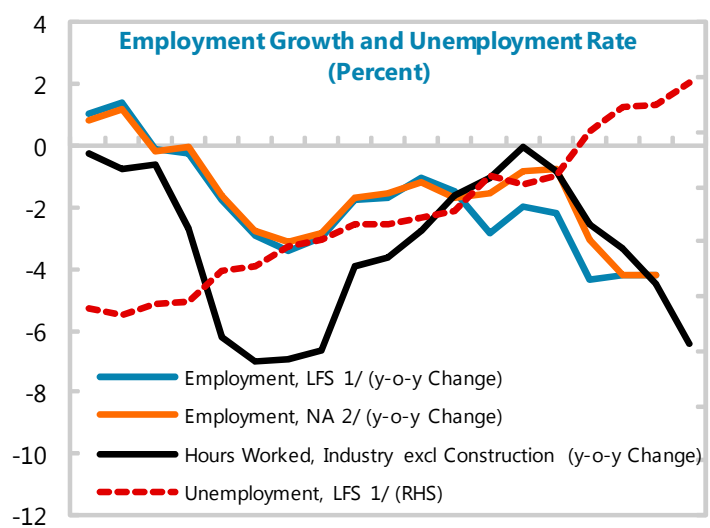

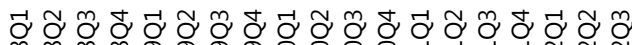

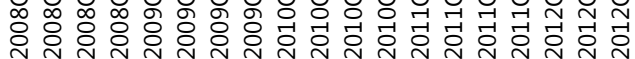

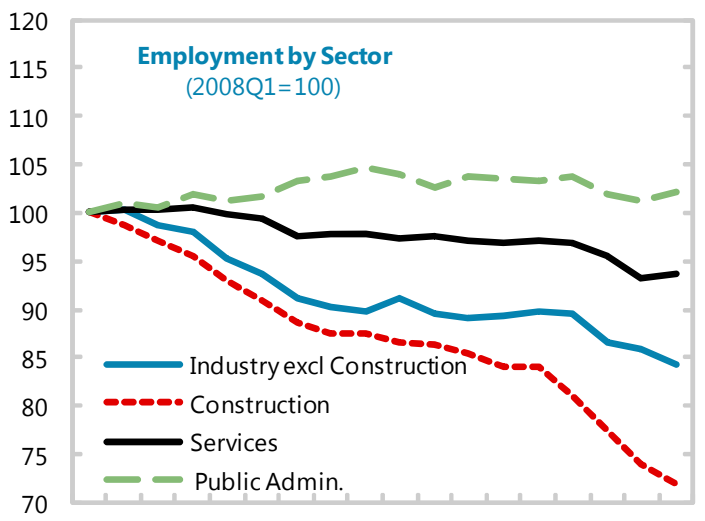

वृ $\tilde{\sigma}$

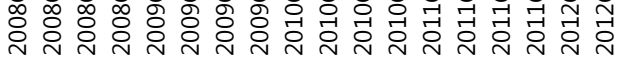

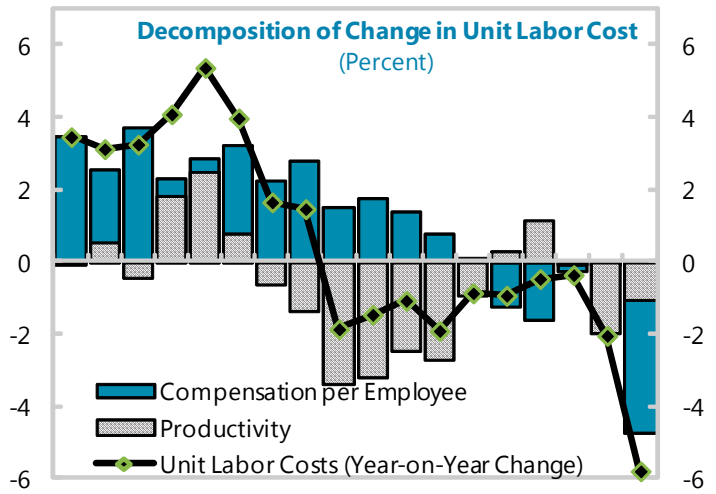

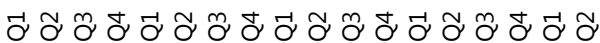

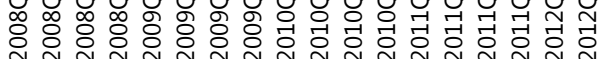

95

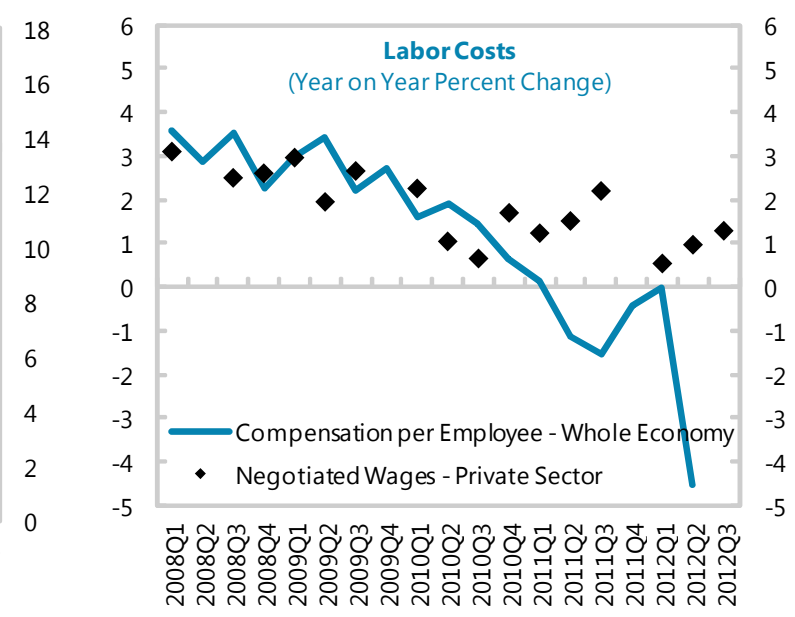

120

115

110

105

100

$90 \quad 95$

85

$80 \quad 90$

75

$70 \quad 85$
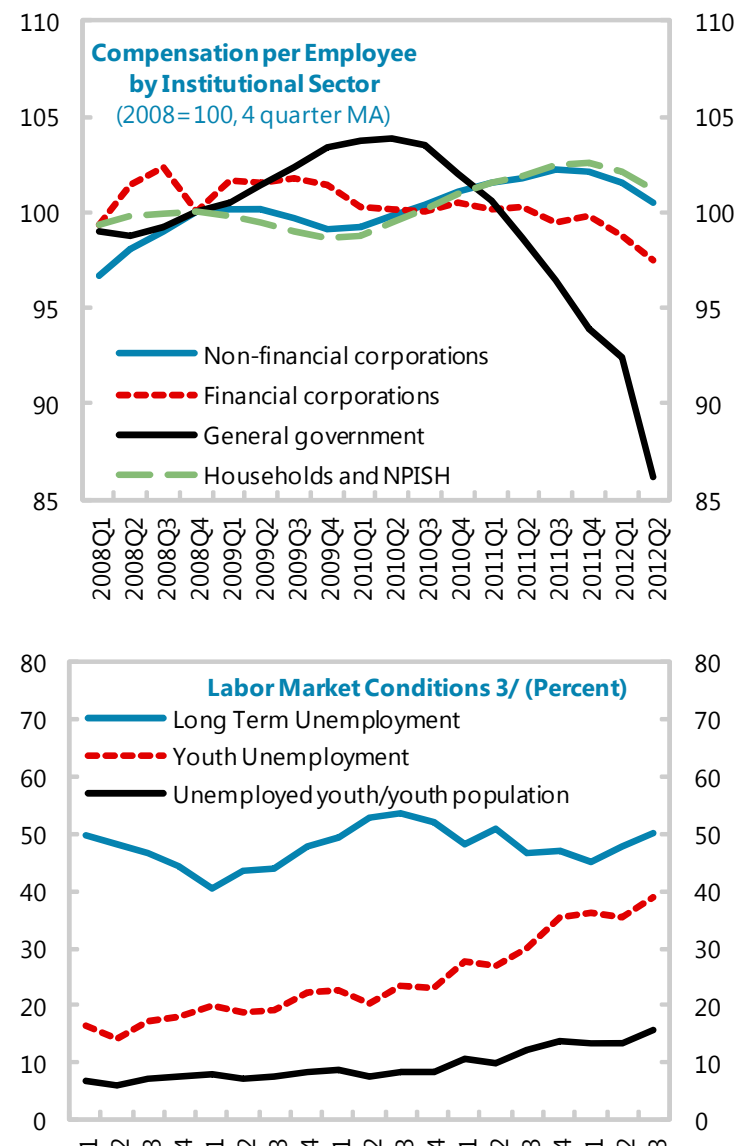

ర్య

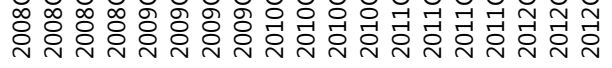

Source: Statistical Office of the European Communities; European Commission; Bank of Portugal; and Fund staff calculations.

1/ Labor Force Survey.

2/ National Accounts.

3/ Long term unemployment rate as percent of total unemployed; youth unemployment rate as percent of youth labor force. 
Figure 3. Portugal: Competitiveness Indicators
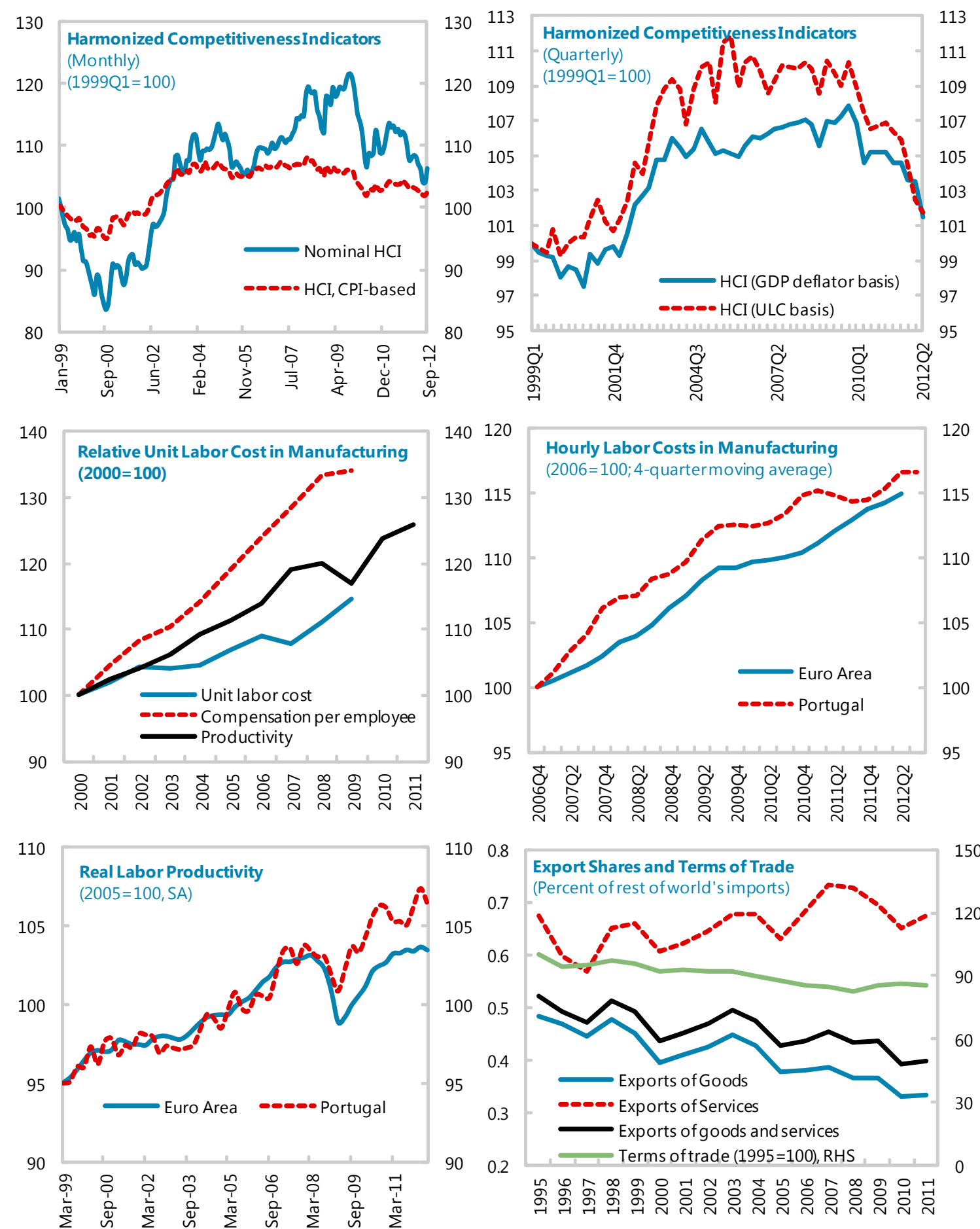

Sources: Statistical Office of the European Communities; European Commission; Bank of Portugal; and Fund staff calculations. 


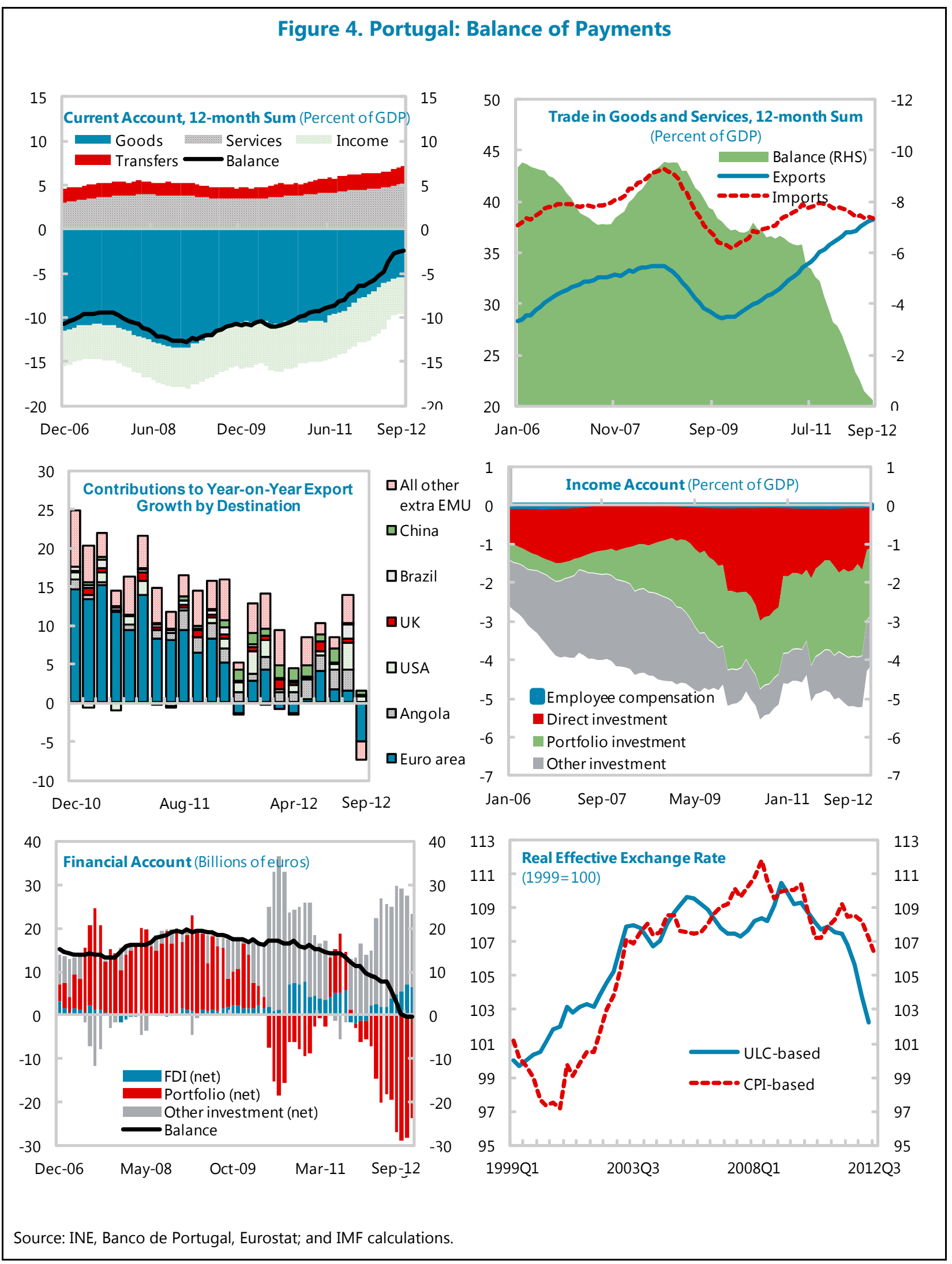


Figure 5. Portugal: Financing of the Economy, 2008-September 2012 1/
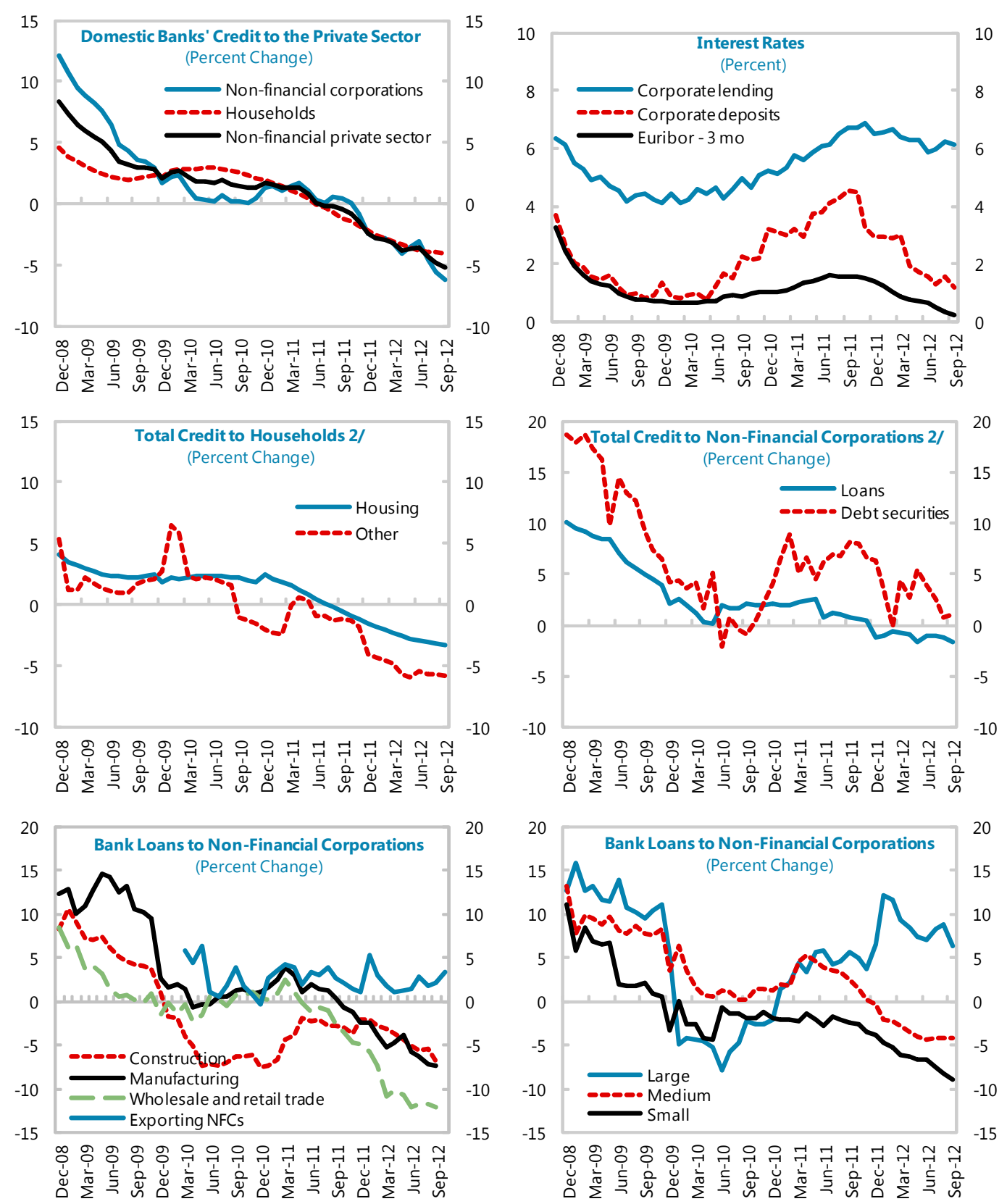

Source: Banco de Portugal.

$1 /$ Credit and loan figures are adjusted for securitisation operations and monthly transactions (calculated using the outstanding amounts corrected of reclassifications, write-offs/write-downs, exchange rate changes and price revaluations). Whenever relevant, figures are additionally adjusted for credit portfolio sales, as well as for other operations with no impact on non-financial corporations' effective financing.

2/ Total credit granted to residents by resident and non-resident entities is reported on a consolidated basis and includes loans, debt securities and trade credits. 


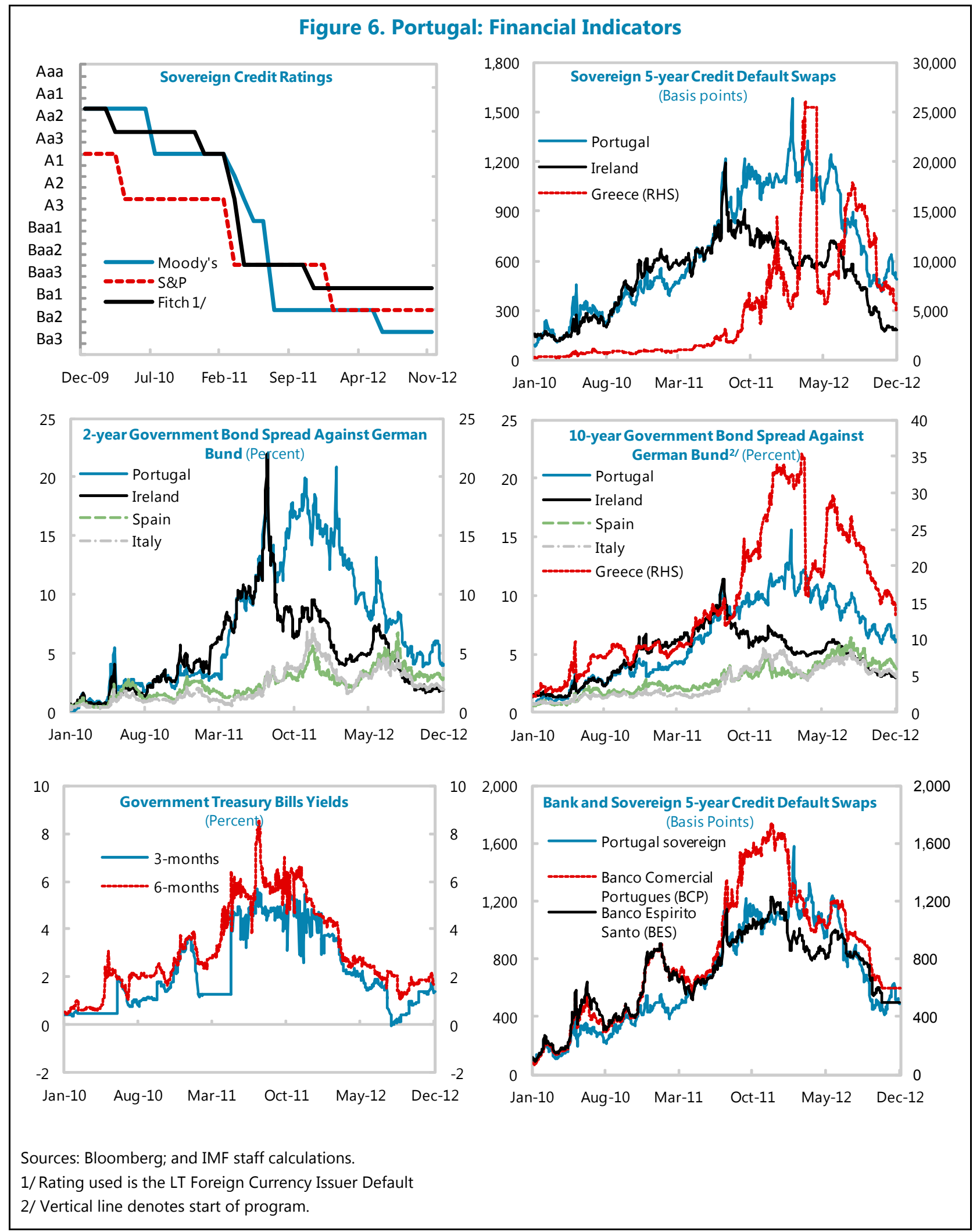


Figure 7. Portugal: External Debt Sustainability: Bound Tests 1/2/

(External Debt in Percent of GDP)
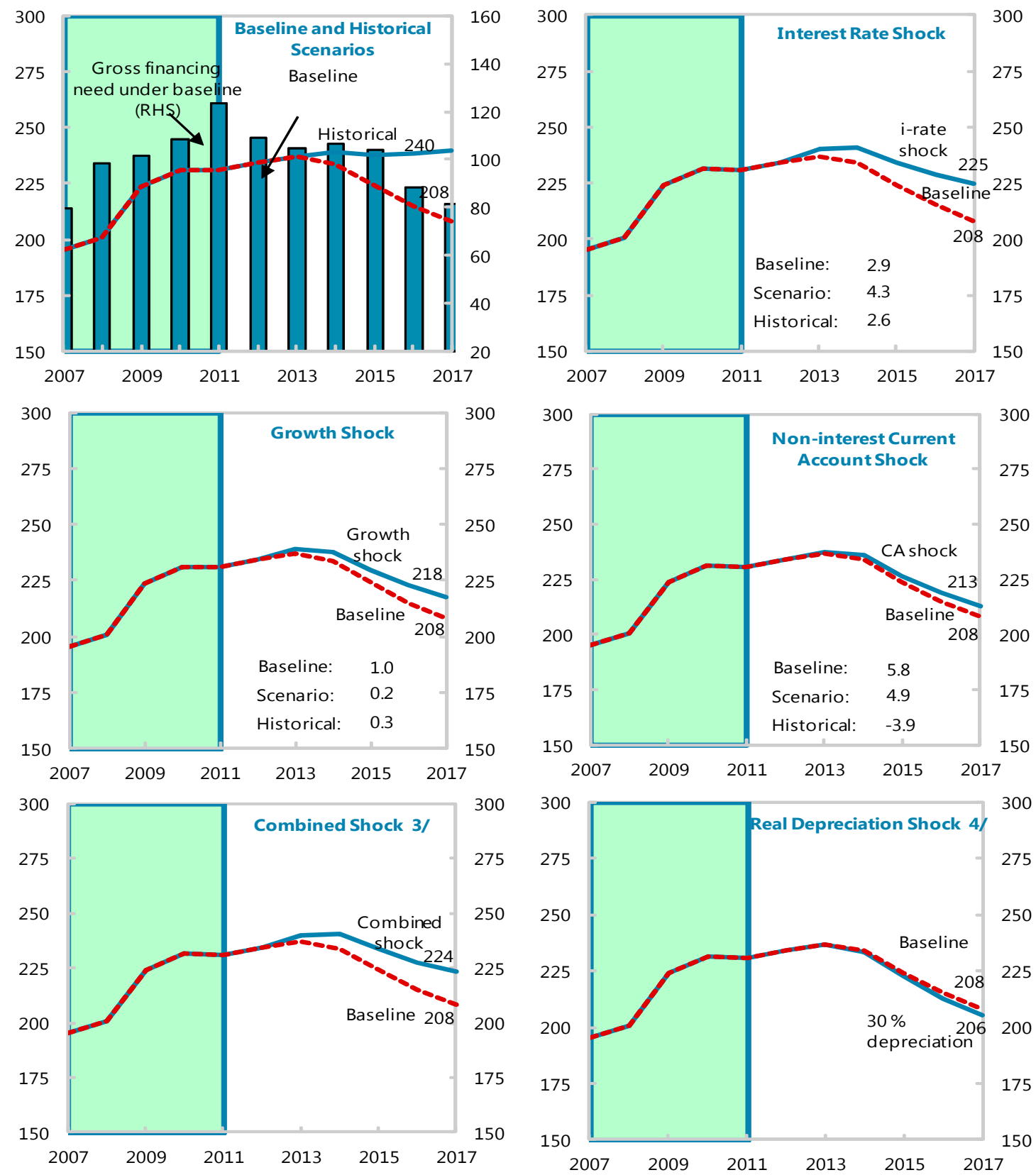

Sources: International Monetary Fund, Country desk data, and IMF staff estimates.

$1 /$ Shaded areas represent actual data. Individual shocks are permanent one-half standard deviation shocks, except the interest rate shock which is a permanent one standard deviation shock. Figures in the boxes represent average projections for the respective variables in the baseline and scenario being presented. Ten-yearhistorical average for the variable is also shown.

2/ For historical scenarios, the historical averages are calculated over the ten-year period, and the information is used to project debt dynamics five years ahead.

3/Permanent $1 / 4$ standard deviation shocks applied to growth rate, and current account balance, and 1/2 standard deviation shock to the real interest rate.

4/ One-time real depreciation of 30 percent occurs in 2010. 
Figure 8. Portugal: Government Debt Sustainability: Bound Tests 1/

(Percent of GDP)

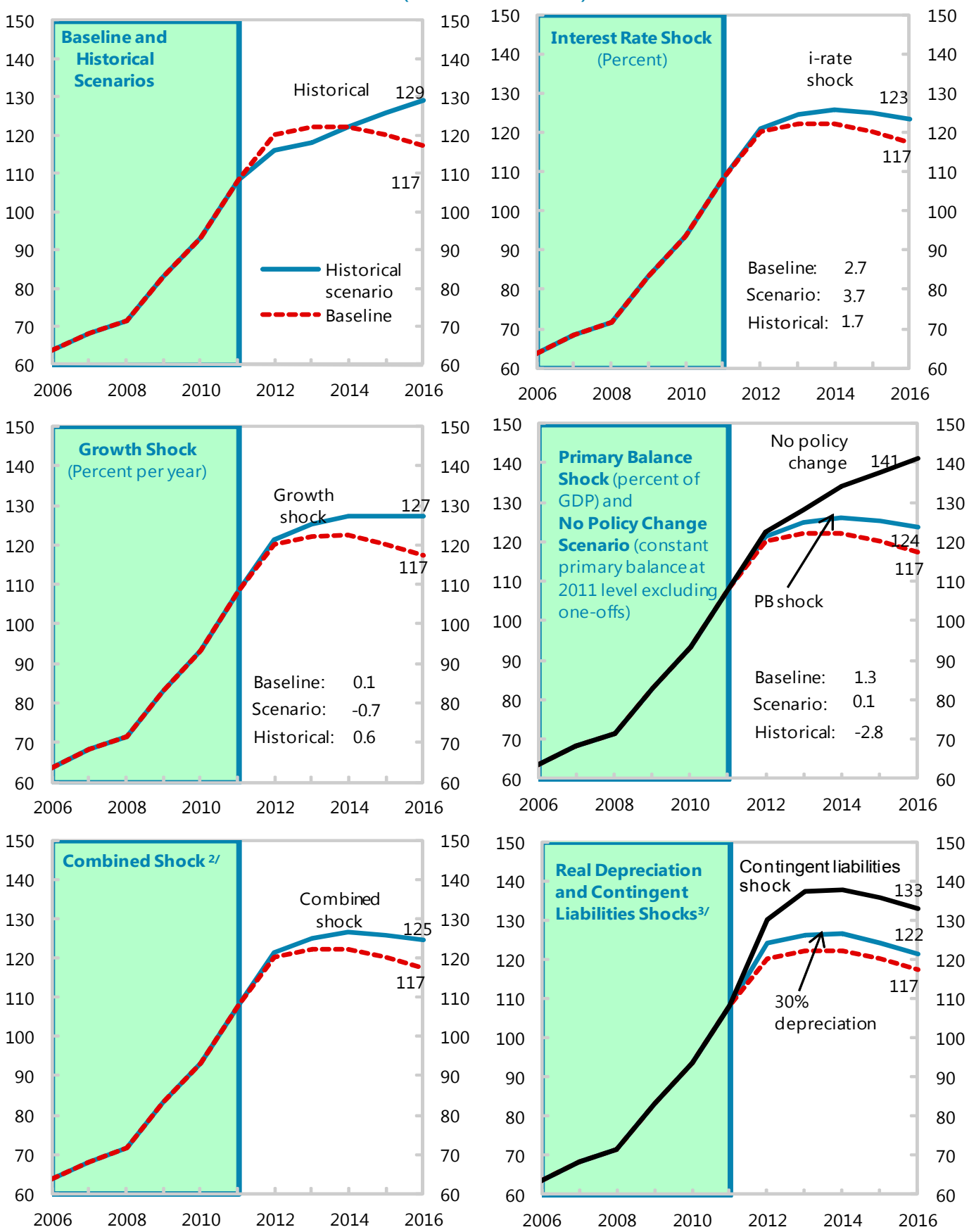

Sources:International Monetary Fund; country desk data; andIMF staff estimates.

$1 /$ Shaded areas represent actual data. Ind ividual shocks are permanent one-half standard deviation shocks.

Figures in the boxes represent average projections for the respective variables in the baseline and scenario being

presented. Ten-year historical average for the variable is also shown.

$2 /$ Permanent $1 / 4$ standard deviation shocks applied to real interest rate, growth rate, and primary balance.

3 /One-time real depreciation of 30 percent and 10 percent of GDP shock to conting ent liabilities occur in 2010,

with real depreciation defined as nominal depreciation (measured by percentage fall in dollar value of local

currency) minus domesticinflation (based on GDP deflator). 


\section{APPENDIX I. PUBLIC DEBTS SUSTAINABILITY ANALYSIS (DSA)}

1. This appendix updates earlier analysis of Portugal's public debt. The basis for the current debt projections-the macroeconomic framework finalized in the course of the sixth review under the EFFdiffers little from the fifth review framework that was used as a basis for the previous DSA. Consequently, the results presented below are very close to the outcome of the previous DSA (see IMF Country Report No. 12/292).

\section{Under the revised baseline, the public debt is} projected to peak at 122 percent of GDP in 2014 and then decline gradually, returning to its pre-crisis level by 2030 . The new, slightly lower, debt peak (compared to 124 percent of GDP in the previous DSA) is largely due to

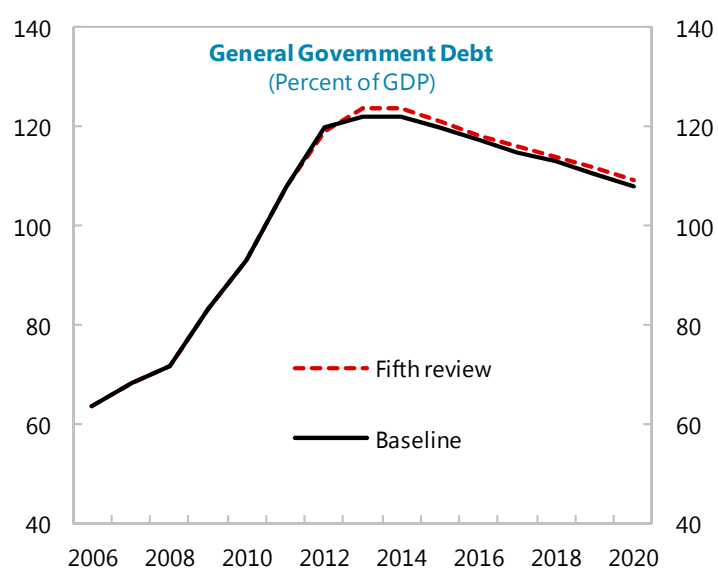
the government's increased use of deposits to reduce the stock of debt, projected to take place in 2013.

\section{The baseline assumes Portugal's return to markets in mid-2013 and full}

\section{implementation of the programmed large fiscal}

adjustment. As in the previous DSA, it is assumed that the yields on Portugal's medium- and long-term obligations will decline from 7 percent in 2013 to 5 percent in the mediumterm and that the structural primary surplus will stabilize at $31 / 4$ percent of GDP. Still, the baseline is not as ambitious as the fiscal adjustment implied by Portugal's current mediumterm budget framework ("fiscal compact"), which sets the structural deficit at 0.5 percent of GDP or below starting in $2015 .^{1}$

\section{Plausible shocks could considerably worsen the}

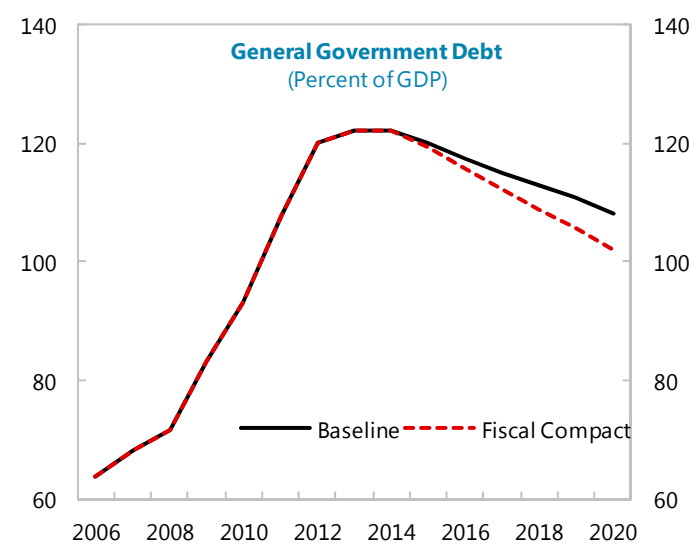

dynamics of Portugal's public debt. A protracted recession or a realization of large contingent liabilities would each lead to a rapid increase in debt-to-GDP ratio (by 10-15 percentage points) followed by a gradual decline. In contrast, a temporary spike in interest rates would raise the debt trajectory only slightly, compared with the baseline. A permanent increase in interest rates would markedly slow down the rate of debt decline. ${ }^{2}$ Finally, a combined shock-protracted recession,

\footnotetext{
${ }^{1}$ Under the baseline, the medium-term structural deficit is between 1.0 and 1.5 percent of GDP.

${ }^{2}$ Protracted recession: five percentage points cumulative decline in growth in 2013-15. Contingent liabilities: 15 percent of GDP in 2013. Temporary interest rate spike: 400 bps on all liabilities in 2013-2015. Permanent increase in interest rates: 200 bps on medium- and long-term debt.
} 
contingent liabilities, and temporary interest rate spike-would render Portugal's debt dynamics unsustainable.
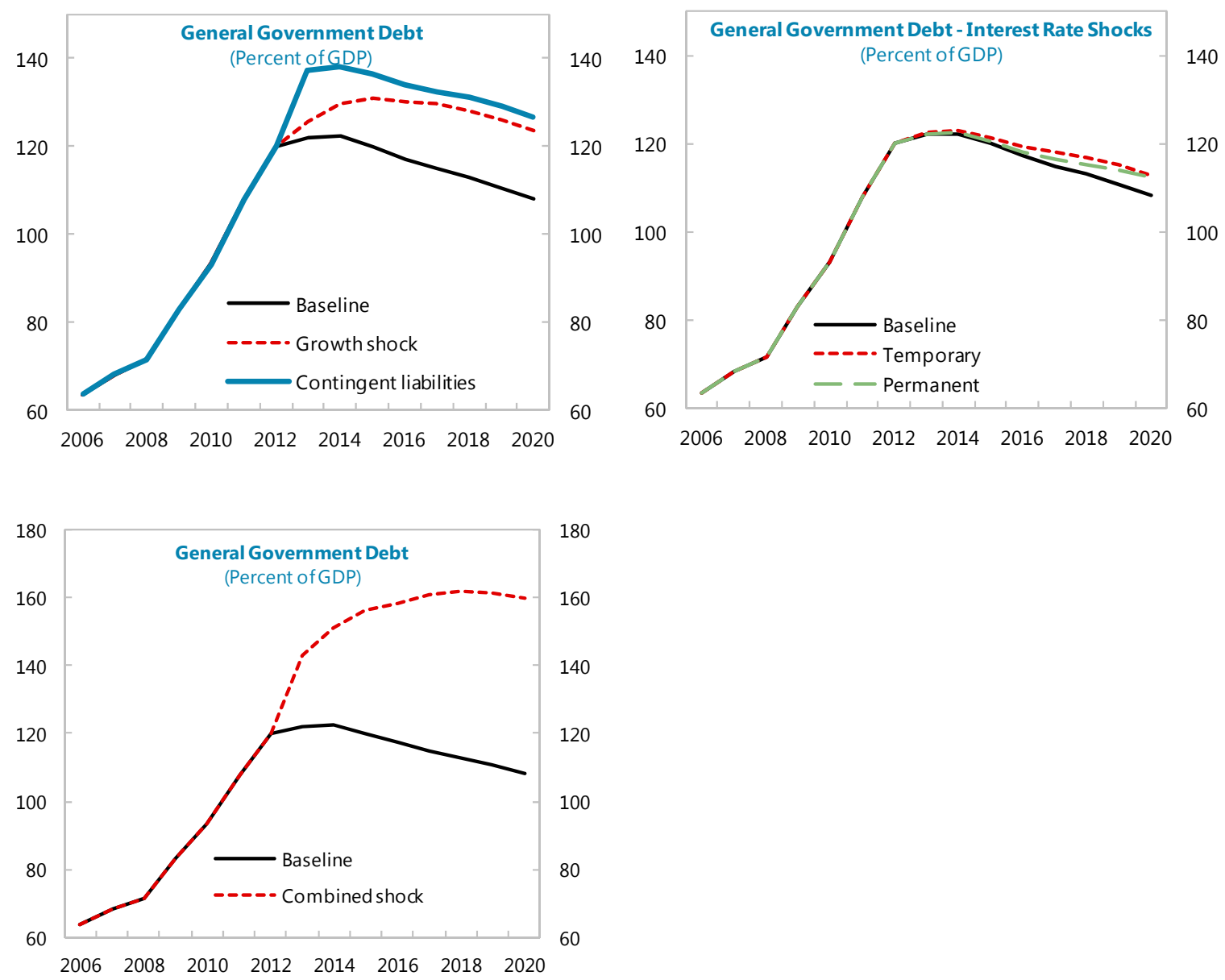

5. Portugal's public debt will remain sustainable under the baseline assumptions and in most cases of plausible shocks. As noted in the previous DSA, this result hinges on successful implementation of the large fiscal adjustment and return to trend growth by 2015. Some of the plausible shocks could lead to unsustainable outcomes, in which case swift policy response will be of the essence. 
This page intentionally left blank

CInternational Monetary Fund. Not for Redistribution 


\section{INTERNATIONAL MONETARY FUND}

\section{PORTUGAL}

STAFF REPORT FOR THE 2012 ARTICLE IV

CONSULTATION-INFORMATIONAL ANNEX

Prepared By

The European Department

(In Consultation with Other Departments)

\section{CONTENTS}

FUND RELATIONS 2

STATISTICAL ISSUES 5 


\section{PORTUGAL-FUND RELATIONS}

(As of November 30, 2012)

\section{Membership Status}

Joined: March 29, 1961; Article VIII

General Resources Account

Quota

Fund holdings of currency

Reserve position in Fund

\section{SDR Department}

Net cumulative allocation

Holdings

Outstanding Purchase and Loans

Extended Arrangements

Latest Financial Arrangement
SDR Million

$1,029.70$

$19,223.96$

207.76

SDR Million

806.48

799.58

SDR Million

$18,402.00$
Percent Quota

100.00

$1,866.95$

20.18

\section{Percent Allocation}

100.00

99.14

Percent Quota

$1,787.12$
Amount Approved

(SDR Million)

$23,742.00$

445.00
Amount Drawn

(SDR Million)

$18,402.00$

259.30

\section{Projected Payments to Fund 1/}

(SDR Million; based on existing use of resources and present holdings of SDRs)

\begin{tabular}{rrrrr}
2012 & \multicolumn{5}{c}{ Forthcoming } \\
& $\mathbf{2 0 1 3}$ & $\mathbf{2 0 1 4}$ & $\mathbf{2 0 1 5}$ & \multicolumn{1}{c}{$\mathbf{2 0 1 6}$} \\
& & 467.58 & $2,287.42$ \\
503.29 & 572.56 & 658.14 & 619.33 \\
$\mathbf{5 0 3 . 2 9}$ & $\mathbf{5 7 2 . 5 6}$ & $\mathbf{1 , 1 2 5 . 7 3}$ & $\mathbf{2 , 9 0 6 . 7 5}$
\end{tabular}

Principal

Charges/Interest

503.29

$\mathbf{5 7 2 . 5 6}$

$1,125.73$

2,906.75

1 / When a member has overdue financial obligations outstanding for more than three months, the amount of such arrears will be shown in this section.

\section{Exchange Rate Arrangement}

Portugal's currency is the euro, which floats freely and independently against other currencies.

Portugal has accepted the obligations of Article VIII, Section 2, 3, and 4, and maintains an exchange system free of restrictions on payments and transfers for current international transactions, other than restrictions notified to the Fund under Decision No. 144 (52/51). 


\section{Safeguards Assessment}

The first-time safeguards assessment of the Banco de Portugal (BdP), concluded in September 2011, found that current safeguards are adequate; it recommended changes to the BdP Law to formalize BdP's autonomy and oversight over the Governor and the executive board in line with good governance practices. In addition, the assessment recommended extending the supervisory responsibilities of the Audit Board to other tasks such as oversight of internal control functions, financial reporting and audit. The authorities have already taken steps to implement the recommendations. A review of Fund related transactions with the debt management agency (IGCP) has been conducted by the Court of Auditors in 2011.

\section{Article IV Consultations}

Portugal is on a 24-month consultation cycle during the Extended Arrangement. Staff discussions for the 2009 Article IV consultation were conducted on a mission to Lisbon during November 19-30, 2009. The Article IV consultation was concluded by the Executive Board on January 20, 2010.

\section{Sixth Review Under the Extended Arrangement}

Discussions were held in Lisbon during November 12-19, 2012.

\section{Technical Assistance:}

\begin{tabular}{|c|c|c|}
\hline Department & Purpose & Date \\
\hline FAD & Public Financial Management & $\begin{array}{l}\text { July, September 2011, March, June, } \\
\text { December } 2012\end{array}$ \\
\hline FAD & Revenue Administration & September, November 2011 \\
\hline FAD & Review of Public Financial Management Legislation & November 2011 \\
\hline FAD & Macro-fiscal Workshop & April 2012 \\
\hline FAD & Tax Policy & June 2012 \\
\hline FAD & Tax Administration & April, September, December 2012 \\
\hline FAD & Public Expenditure Review & October 2012 \\
\hline FAD & Taxpayer Compliance Management (Short-term expert) & November 2012 \\
\hline FAD & Long-term Resident Public Financial Management Advisor & December 2012 - December 2013 \\
\hline LEG & $\begin{array}{l}\text { Bank early intervention, resolution and deposit insurance } \\
\text { framework }\end{array}$ & August 2011 \\
\hline LEG & Corporate insolvency regime and debt restructuring & September 2011 \\
\hline LEG & Workshop on judicial reform & April 2012 \\
\hline LEG & Judicial reform & July, September 2012 \\
\hline MCM & $\begin{array}{l}\text { Monitoring Framework of the Corporate and Household } \\
\text { Sectors }\end{array}$ & July 2011 \\
\hline MCM & Support to the Special On-Site Inspections program & July 2011-Februrary 2012 \\
\hline MCM & Assessment of Private Sector Financing & January 2012 \\
\hline MCM & Bank Resolution & August 2012 \\
\hline
\end{tabular}




\section{Resident Representative}

Mr. Albert Jaeger assumed his position in October 2011; Mr. Marcos Rietti Souto assumed his position in September, 2011. 


\section{PORTUGAL-STATISTICAL ISSUES}

(As of December 10, 2012)

\section{Assessment of Data Adequacy for Surveillance}

General. Data provision to the Fund is adequate for surveillance purposes.

Real Sector. Since 2000 INE publishes a full set of national accounts based on ESA95 methodology, including quarterly GDP estimates.

Fiscal sector. Data have undergone a number of revisions during the transition to ESA95, sizably altering revenue and expenditure and hampering comparisons across years. From 2001 onward, budgets have been presented in a manner consistent with recent changes in national and fiscal accounting methodology. Quarterly general government statistics on an accrual basis are available as derived from the national accounts statistics.

Trade and Balance of Payments. Data are provided according to the IMF's fifth edition of the Balance of Payments Manual. The external trade data meet the timeliness standards. The portfolio investment collection system has a simplified threshold of $€ 500$ million, which is relatively high in comparison with many EU countries. The authorities estimate however, that only about 1.5 percent of transactions are not captured on a monthly basis by this threshold, and that this reporting simplification does not significantly hamper the quality of the monthly balance of payments. Moreover, they indicate that all transactions below this threshold are included in the first release of the annual balance of payments data, and the monthly numbers are revised accordingly.

\section{Data Standards and Quality}

Portugal is subject to the statistical requirements $\quad$ No data ROSC is available. and timeliness and reporting standards of Eurostat and the European Central Bank (ECB). Portugal subscribes to the Special Data Dissemination Standard (SDDS), and the relevant metadata have been posted on the Dissemination Standards Bulletin Board. 
Portugal-Table of Common Indicators Required for Surveillance

(As of December 10, 2012)

\begin{tabular}{|c|c|c|c|c|c|}
\hline & $\begin{array}{c}\text { Date of } \\
\text { Latest } \\
\text { Observation }\end{array}$ & $\begin{array}{c}\text { Date } \\
\text { Received }\end{array}$ & $\begin{array}{l}\text { Frequency } \\
\text { of Data }^{6}\end{array}$ & $\begin{array}{l}\text { Frequency } \\
\text { of } \\
\text { Reporting }^{6}\end{array}$ & $\begin{array}{l}\text { Frequency } \\
\text { of } \\
\text { Publication }\end{array}$ \\
\hline Exchange Rates & $12 / 07 / 12$ & $12 / 07 / 12$ & D & D & D \\
\hline $\begin{array}{l}\text { International Reserve Assets and } \\
\text { Reserve Liabilities of the Monetary } \\
\text { Authorities }^{1}\end{array}$ & $11 / 12$ & $12 / 12$ & M & M & M \\
\hline Reserve/Base Money & $10 / 12$ & $11 / 12$ & M & M & M \\
\hline Broad Money & $10 / 12$ & $11 / 12$ & M & M & M \\
\hline Central Bank Balance Sheet & $11 / 12$ & $12 / 12$ & M & M & M \\
\hline $\begin{array}{l}\text { Consolidated Balance Sheet of the } \\
\text { Banking System }\end{array}$ & $10 / 12$ & $11 / 12$ & M & M & M \\
\hline Interest Rates ${ }^{2}$ & $10 / 12$ & $11 / 12$ & M & M & M \\
\hline Consumer Price Index & $10 / 12$ & $11 / 12$ & M & M & M \\
\hline $\begin{array}{l}\text { Revenue, Expenditure, Balance and } \\
\text { Composition of Financing }{ }^{3}-\text { General } \\
\text { Government }^{4}\end{array}$ & $10 / 12$ & $11 / 12$ & M & M & M \\
\hline $\begin{array}{l}\text { Revenue, Expenditure, Balance and } \\
\text { Composition of Financing }{ }^{3}-\text { Central } \\
\text { Government }\end{array}$ & $10 / 12$ & $11 / 12$ & M & M & M \\
\hline $\begin{array}{l}\text { Stocks of Central Government and } \\
\text { Central Government-Guaranteed } \\
\text { Debt }^{5}\end{array}$ & $10 / 12$ & $11 / 12$ & M & M & M \\
\hline External Current Account Balance & $09 / 12$ & $11 / 12$ & M & M & M \\
\hline $\begin{array}{l}\text { Exports and Imports of Goods and } \\
\text { Services }\end{array}$ & 09/12 & $10 / 12$ & M & M & M \\
\hline GDP/GNP & 2012:Q3 & $12 / 12$ & Q & Q & Q \\
\hline Gross External Debt & 2012:Q2 & 09/12 & Q & Q & Q \\
\hline International Investment Position & 2012:Q2 & 09/12 & Q & Q & Q \\
\hline
\end{tabular}

${ }^{1}$ Any reserve assets that are pledged or otherwise encumbered should be specified separately. Also, data should comprise shortterm liabilities linked to a foreign currency but settled by other means as well as the notional values of financial derivatives to pay and to receive foreign currency, including those linked to a foreign currency but settled by other means.

${ }^{2}$ Both market-based and officially determined, including discount rates, money market rates, rates on treasury bills, notes and bonds.

${ }^{3}$ Foreign, domestic bank, and domestic nonbank financing.

${ }^{4}$ The general government consists the central government (budgetary funds, extra budgetary funds, and social security funds) and state and local governments.

${ }^{5}$ Including currency and maturity composition.

${ }^{6}$ Daily (D), weekly (W), monthly (M), quarterly (Q), annually (A), irregular (I); and not available (NA). 


\section{INTERNATIONAL MONETARY FUND}

\section{PORTUGAL}

December 26, 2012

\section{SIXTH REVIEW UNDER THE EXTENDED ARRANGEMENT AND REQUEST FOR WAIVERS OF APPLICABILITY OF END- DECEMBER PERFORMANCE CRITERIA}

\section{EXECUTIVE SUMMARY}

Economic developments and program performance. Program implementation remains good: all end-September PCs and structural benchmarks for the review were met. Fiscal performance has been broadly in line with the program, and external adjustment continues to proceed at a faster pace that envisaged. Reflecting these positive achievements and an improvement in market conditions at the euro area level, yields on government bonds have continued to decline, reaching their lowest level since early 2011.

Sixth Review. Policy discussions focused on the parameters for the newly launched comprehensive public expenditure review and a new initiative to make the corporate income tax system more conducive to investment and competitiveness. Discussions also covered how to address the risk of revenue shortfalls, the tight credit conditions faced by firms, and further steps to improve labor market flexibility.

Outlook and risks. Domestic activity indicators are still strongly negative. Output is expected to contract by 3 percent this year, and there are downside risks to the expected 1-percent contraction next year. Staff expects a recovery in the second half of 2013, but much will also depend on broader euro area developments. The debt outlook remains sustainable, although the room for maneuver is narrow-under the new baseline public debt will peak at 122 percent of GDP, declining gradually after 2014.

Staff supports the authorities' request for completion of the sixth review, including waivers of applicability of the end-December performance criteria. The purchase subject to completion of this review would be in an amount equivalent to SDR 724 million. 


\section{Approved By}

Poul M. Thomsen and

Martin Mühleisen
Discussions took place during November 12-19 in Lisbon. The staff team comprised A. Aemro Selassie (head), D. Gershenson, M. Goretti, H. Lin, and S. Roudet (all EUR); A. Piris (SPR); A. Lemgruber (FAD); C. Verkoren (MCM); W. Bergthaler and D. Chew (LEG); and A. Jaeger and M. Souto (Res. Reps). Mr. Cardoso (OED) also participated in meetings.

\section{CONTENTS}

BACKGROUND

ECONOMIC DEVELOPMENTS AND OUTLOOK

ADVANCING FISCAL CONSOLIDATION__ $\underline{6}$

A. Recent Fiscal Developments__ $\underline{6}$

B. Policy Discussions _

SAFEGUARDING FINANCIAL STABILITY __ $\underline{9}$

A. Recent Financial Developments _ 9

B. Policy Discussions _ 11

BOOSTING COMPETITIVENESS AND GROWTH __ 12

A. Recent Structural Developments __ 12

B. Policy Discussions __ $\underline{13}$

FINANCING AND RISKS __ 14

STAFF APPRAISAL _ 16

\section{TABLES}

1. General Government Financing Requirements and Sources__ $\underline{19}$

2. External Financing Requirements and Sources, 2009-17__ $\underline{20}$

3. Access and Phasing Under the Extended Arrangement, 2011-14_ 21

4. Indicators of Fund Credit __ $\underline{22}$

BOXES

1. Progress in Judicial Reform 


\section{APPENDIXES}

I. Letter of Intent

Attachments

I. Memorandum of Economic and Financial Policies $\underline{25}$

II. Technical Memorandum of Understanding

II. Letter of Intent to the European Commission and the European Central Bank

$\underline{41}$

Attachment

I. Memorandum of Understanding on Specific Economic Policy Conditionality $\underline{43}$ 


\section{BACKGROUND}

1. The program is broadly on track but downside risks remain significant. All performance criteria for which data are available and structural benchmarks for the $6^{\text {th }}$ review have been met. More broadly, external adjustment continues to exceed expectations; fiscal performance is largely in line with the program objectives; financial stability continues to be maintained; and structural reforms are being advanced. In this context, and playing off the more benign market environment, sovereign yields have continued to decline to their lowest levels since early 2011. Some corporates-including banks-have also resumed borrowing in international capital markets at medium-term maturities. Nevertheless, domestic activity indicators are still strongly negative, and support from external demand is hostage to broader euro area economic developments. With revenue collections already on the weak side, this points to downside risks to the macroeconomic outlook and fiscal targets.

2. Program implementation has remained strong amidst a more tense social and political climate. The 2013 budget was adopted by Parliament, consistent with earlier understandings. The government has launched a comprehensive public expenditure review to identify the permanent measures that will underpin the adjustment effort over the next several years. In addition, important pieces of legislation have been submitted to Parliament or adopted, moving the structural reform agenda forward. But austerity fatigue is also running high. With unemployment set to continue rising and disposable incomes set for a further fall, opposition parties and civil society organizations are increasingly voicing strong objections to key elements of the program.

\section{This sixth program review was conducted in conjunction with the $\mathbf{2 0 1 2}$ Article IV} discussions. A separate Article IV report presents an analysis of the institutional weaknesses and policy failures that led to the 2011 economic crisis, progress to date in addressing economic imbalances, and medium-term prospects and risks. This review report focuses on the program review aspects of the mission's discussions. The centerpieces of policy discussions in this review were: (i) the parameters for the newly launched comprehensive public expenditure review and (ii) a new initiative to make the corporate income tax system more conducive to investment and competitiveness. Discussions also covered how to best address the risk of revenue shortfalls, the still tight credit conditions faced by firms, and further steps to improve labor market efficiency.

\section{ECONOMIC DEVELOPMENTS AND OUTLOOK}

4. Output is so far evolving as envisaged under the program baseline, but there are signs of weakness. Real output contracted by 0.9 percent (quarter-on-quarter) in the third quarter, somewhat smaller than the 1.1 percent expected under the program. This reflected stronger-thanexpected private sector activity, with signs of the contraction in industrial production bottoming out in the third quarter. However, more recent high frequency confidence and activity indicators point to possible further weakness going forward. On balance, staff and the authorities agreed to maintain the growth forecast broadly unchanged-with output contracting by 3 percent this year and the 
recession extending into next year (-1 percent)—while recognizing that downside risks are significant.

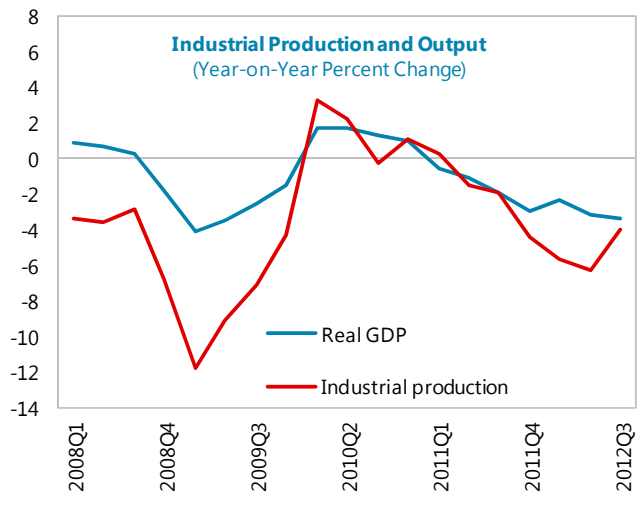

Source: Eurostat; INE; and IMF staff calculations.

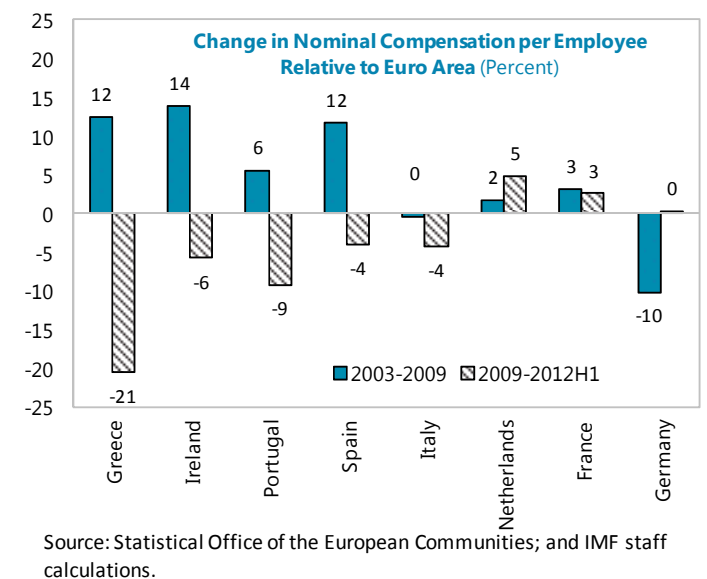

calculations.

\section{Staff still expects a recovery in the second half of 2013 , driven by a turnaround in} investment; but much will also depend on broader euro area developments. The recovery is expected to be underpinned by a gradual increase in investment outlays by more export-oriented firms as capacity constraints become more binding. Risks to this forecast remain non-trivial. For instance, there could be further drag on growth from fiscal adjustment or corporate deleveraging, weighing much more on spending and employment than currently assumed. This outlook also requires that the conditions in the euro area do not deteriorate subtstantially and that export demand picks up in the second half of 2013. (see Article IV report for more details on the macroeconomic outlook and related risks).

\section{Reflecting depressed activity, labor market adjustment continues and inflation}

\section{continues to run well below the euro area average.}

Employment in the third quarter declined by 4 percent from a year ago, with unemployment rate further rising to 15.8 percent. Labor shedding has been accompanied by a fast decline in labor compensation. While this reflected in large part the cuts in public sector wages (soon to be partially reversed), increases in private sector negotiated wages have also been fairly low (1 percent year-on-year during the first three quarters). Overall, unit labor costs for the economy as a whole have declined by 53/4 percent from their 2009

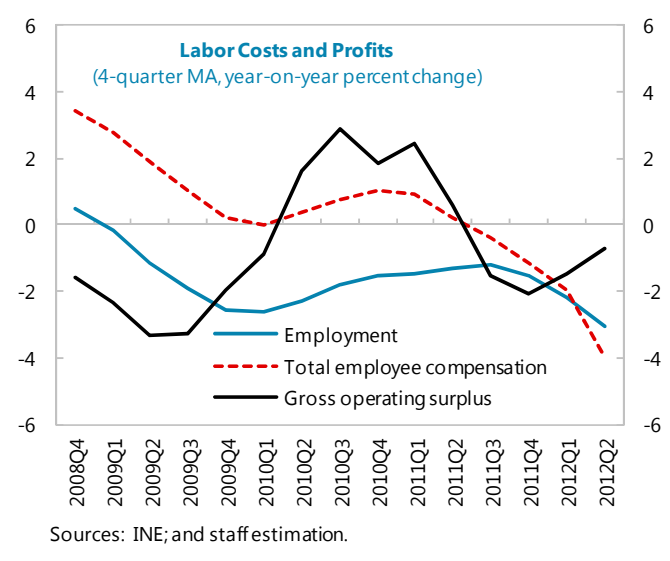
peak (Figures 2 and 3 in Article IV staff report). Inflation at constant tax rates has been declining since February, averaging 1 percent for the first nine months of the year-about 11/4 percentage points lower than the euro area average. 


\section{The speed of external adjustment continues to exceed expectations, prompting an} upward revision to the current account balance projections. Exports of goods and services fell by close to 7 percent year-on-year in September, reflecting a strike by port workers in reaction to the ongoing reforms (see below), as well as weakening demand in Europe, but growth of goods exports picked up again to 5 percent in October. Overall, year-to-date export growth was robust (above 5 percent), led by strong expansion in exports of goods to non-EU destinations (up 23 percent). As a result, Portugal's market share in most export markets (including in the EU) has been slowly rising. With imports still declining (at close to 6 percent year-to-date), the current account continues to adjust at a faster pace than projected. The 12-month rolling deficit reached 21/2 percent of GDP in September-representing an adjustment of 10 percentage points from the low point in

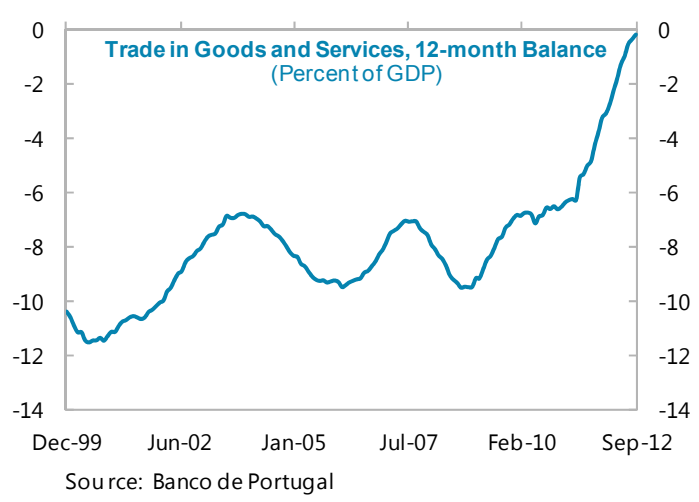
late 2008-or close to staff's revised, but still conservative year-end projection. The current account deficit is now projected to reach about 1 percent of GDP in 2013, compared to 1.7 percent of GDP at the time of the $5^{\text {th }}$ review.

8. The debt outlook remains sustainable, although the room for maneuver is narrow. Public debt will peak at some 122 percent of GDP in 2013-14 and start declining steadily thereafter. ${ }^{1}$ As before, the debt path remains very sensitive to the economic growth and interest rate assumptions. And the possible migration of contingent liabilities from either state-owned enterprises or the highly indebted nonfinancial corporate sector to the sovereign balance sheet, via the banking system, remains a high risk factor for the debt trajectory. As noted in earlier reports, the combination of plausible shocks could generate an unsustainable dynamics (see DSA appendix in Article IV report).

\section{ADVANCING FISCAL CONSOLIDATION}

\section{A. Recent Fiscal Developments}

9. Revenue performance continues to show signs of weakness. State tax revenues were about 0.2 percent of GDP below projections at end-October (on a cumulative basis), reflecting mainly the continuing shift in economic activity from domestic demand to the lighter-taxed exports and an unanticipated increase in corporate income tax reimbursements. In spite of this, and contrary to initial expectation, the end-September performance criterion on the government cash deficit was

\footnotetext{
${ }^{1}$ Gross debt is now projected to peak around 2 percentage points of GDP lower than expected at the time of the Fifth review reflecting the additional use of government deposits for deficit financing resulting from the ongoing centralization of cash management as well as favorable exchange rate developments.
} 
met, as the revenue underperformance was more than offset by a combination of the tight control over spending and delays in budget execution. ${ }^{2}$

\section{The $\mathbf{2 0 1 3}$ budget was approved by} Parliament at the end of November. The budget, which is in line with the understanding reached at the time of the $5^{\text {th }}$

\begin{tabular}{lccccc}
\multicolumn{6}{c}{$\begin{array}{c}\text { General Government Fiscal Indicators } \\
\text { (Percent of GDP, unless otherwise noted) }\end{array}$} \\
\hline & 2010 & 2011 & 2012 & 2013 & 2014 \\
\hline Revenue & 41.4 & 45.0 & 40.6 & 42.3 & 42.5 \\
Expenditure & 51.3 & 49.4 & 45.6 & 46.9 & 45.0 \\
Overall balance & -9.8 & -4.4 & -5.0 & -4.5 & -2.5 \\
$\quad$ excluding one-offs & -9.2 & -7.4 & -6.0 & -4.5 & -2.5 \\
Primary balance & -7.0 & -0.4 & -0.8 & -0.2 & 2.1 \\
Primary structural balance 1/ & -6.2 & -2.6 & -0.1 & 1.8 & 3.6 \\
\hline
\end{tabular}

Sources: National Authorities; and IMF staff estimates. $1 /$ In percent of potential GDP review (see IMF Country Report No. 12/292 for a full discussion), is consistent with achieving the program's $4 \frac{1}{2} 2$ percent of GDP deficit target on current policies and prospects. The consolidation is underpinned by a mixture of revenue increases, which account for 80 percent of the total adjustment, and expenditure cuts (MEFP \3). The budget is an important step in putting Portugal's finances on a sustainable footing. It postulates continued fiscal consolidation, with a structural primary adjustment close to 2 percentage points of potential GDP. Successful implementation will bring the structural primary adjustment in 2011-13 to 80 percent of the required total.

\section{B. Policy Discussions}

\section{The mission discussed ways to address the significant downside risks to the fiscal targets:}

- Given the revenue underperformance, staff estimates that, in the absence of offsetting measures, the 2012 deficit would be about $1 / 4$ percentage points of GDP higher than the target of 5 percent of GDP (including receipts from the sale of an airport concession). ${ }^{3}$ But the authorities were adamant this would be offset through tighter spending execution. To this end, all new capital spending commitments have been frozen since end-September. There is also a risk of slippages in the execution of the program with Madeira, but the authorities are proactively containing spending to avoid any impact on the deficit target.

- With the underlying revenue slippage set to carry over to next year, and given the risks to the macroeconomic outlook, the authorities have agreed to prepare contingency measures for 2013 worth at least $1 / 2$ percent of GDP on the spending side-mainly by frontloading the measures from the ongoing public expenditure review.

\footnotetext{
${ }^{2}$ With the preliminary data indicating that the end-September PC on government cash balance might have been missed, the authorities had requested a waiver of non-observance, which was granted at the time of the fifth review.

${ }^{3}$ As noted in the staff report for the fifth review, reaching the 5.0 percent deficit target is contingent on the above-the-line classification of the expected revenue from the sale of airport concessionaire ANA (0.7 percent of GDP). Staff and the authorities are still discussing the proper statistical treatment. The outcome of the discussion will not affect the magnitude of Portugal's fiscal consolidation effort.
} 


\section{Discussions also covered the scope and parameters of the recently initiated public}

expenditure review. The fiscal adjustment envisaged for 2013 relies heavily on raising revenues. This has prompted considerable public disquiet, and there is some political consensus for a thorough reassessment of the country's spending priorities. To this end, the authorities have launched a comprehensive expenditure review-including with input from Fund technical assistance - with the aim of improving the efficiency and sustainability of the government operations. In quantitative terms, the objective is to identify savings of up to $€ 4$ billion (close to 2.5 percent of GDP) during the course of 2013-14. The authorities plan to discuss their findings with staff at the time of the next program review in February 2013 (MEFP ॠ4).

13. The mission strongly welcomed the expenditure review. With the tax-to-GDP ratio already in line with peers and the 2013 budget set to push this ratio even higher, a large part of the medium-term fiscal adjustment will need to come from expenditure restraint. This would help bring the adjustment mix closer to the original program objective-one third revenue, two thirds expenditure. And given that Portugal's spending is heavily concentrated on pensions and public wages-accounting for about two-thirds of total spending, these outlays will have to be at the center of spending reforms. These areas are particularly sensitive; and it will be important to ensure a broad, open, and transparent consultation process to build domestic support for these critical reforms.

\section{Fiscal structural reforms continue to focus on minimizing fiscal risks.}

- Public financial management. Following broad consultation with the various stakeholders and FAD TA, the government is on track to meet the end-year structural benchmark on the submission of the local and regional finance laws to Parliament. The total stock of domestic arrears was further reduced-to 2.4 percent of GDP at end-October-reflecting repayments of health sector arrears under a settlement program agreed earlier. But going beyond the parameters of this program, the authorities plan to settle an additional €432 million in arrears. The mission expressed its misgiving, stressing that underlying accumulation of arrears is not yet under control, especially in SOE hospitals. The authorities argued that with the new expenditure commitment control systems now rolled out in most spending units, the underlying accumulation of arrears will soon be stopped. Moreover, they agreed that this repayment would not proceed until there is evidence that: (i) cash management needs are carefully prioritized; and (ii) the impact on the deficit is properly assessed.

- Revenue administration. Given the revenue underperformance this year and the greater reliance of the 2013 adjustment on tax handles, the focus on tax noncompliance is being strengthened. In particular, the authorities are working toward a new compliance risk management approach over a 2-3 year period, with two projects focusing on High Net Wealth Individuals (HNWI) and 
Self-Employed Professionals (SEP) to be implemented immediately. ${ }^{4}$ The end-December structural benchmark on the implementation of the Large Taxpayer Office was met. Progress has also been achieved in resolving high value tax court cases. Nevertheless, some organizational reforms, such as streamlining the excessive number of local offices of the revenue administration, have been postponed. Staff also stressed the need for a deeper analysis on compliance trends and performance indicators, including the adoption of a risk management unit.

- Public-private partnerships (PPPS). The authorities have developed a plan to reduce PPP costs by about $€ 250$ million in 2013, and up to $€ 400$ million after 2014. It includes several measures such as the reduction of scope of contracts, changes in the toll framework, and reduction of the private partners' internal rate of return. The mission stressed the need to ensure the long-term fiscal sustainability in the renegotiation process, minimizing contingent risks and promoting transparency.

\section{The objective of restoring operational balance for the SOE sector before end-2012 has} been achieved. Further cost-cutting is still needed in some firms that still show deficits, and they have been asked to present plans for the next fiscal year accordingly, while firms in surplus have been asked to find ways of generating new revenue streams from non-core activities to help pay down debts and meet the partial reinstatement of the salaries. The authorities have generally been successful in ensuring that amortizing debts are rolled over, and no new use of direct treasury financing for firms outside the perimeter of general government is foreseen in the 2013 budget. But rolling over high legacy debts in several firms remains a risk.

16. The privatization process is on track. The authorities have received bids for the airport concession company ANA. Completion of the sale is expected in early in 2013. The sale process for the postal company, CTT, is expected to be launched in the second quarter of 2013, and completed by year-end, while privatization of the rail cargo company CP Carga is expected to be launched in early 2013. Overall, interest has been strong in the privatization process, and completion of the ANA transaction should bring privatization proceeds to about 80 percent of the originally programmed revenues.

\section{SAFEGUARDING FINANCIAL STABILITY}

\section{A. Recent Financial Developments}

\section{Banks' capital and liquidity conditions have improved markedly. The capital} augmentation exercise of the banks monitored under the program is nearly complete, with all the major banks successfully recapitalized. The proceeds of the capital increase have been used by some

\footnotetext{
${ }^{4}$ Gross income reported by SEP fell by 24 percent between 2010 and 2011, while the income reported by wage earners fell only by 3 percent. Similarly, the reported taxable income of the two highest tax brackets-where HNWI are concentrated-fell significantly more than the other PIT brackets over the same period.
} 
banks to purchase sovereign securities or reduce reliance on ECB refinancing operations at shorter maturities. Eurosystem liquidity support currently stands at about $€ 58$ billion, of which over 85 percent from the 3-year LTRO. Deposits remain broadly stable, with recent movements in customer deposits mainly driven by renewed retail appetite for debt instruments. Moreover, two Portuguese banks have recently reaccessed international bond markets in the wake of improved funding conditions in the broader euro area.

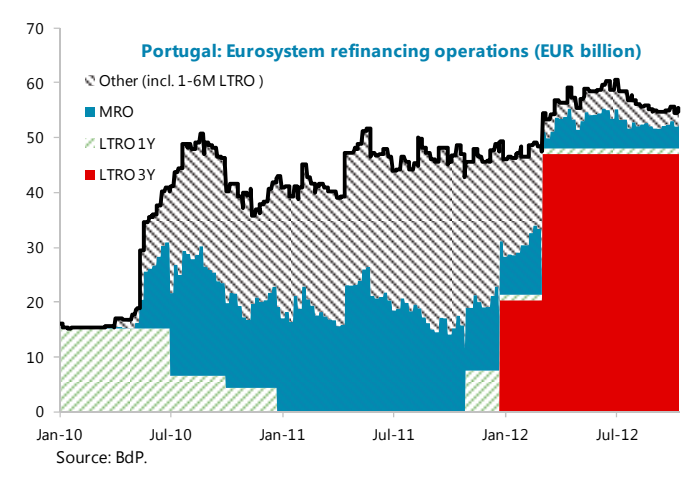

\section{But credit conditions remain among the tightest in the euro area.}

- While large corporations maintain reasonable access to financing, smaller firms are facing particularly difficult credit conditions. Bank credit growth to large firms in recent months has remained positive, coupled with several international bond issues by large firms in recent months_for the first time since early 2011-as well as placements in domestic retail markets. ${ }^{5}$ However, credit pressures remain elevated for small and micro enterprises, notably those operating in the non-tradable sectors. Credit to these firms by domestic banks has been declining at a pace of about 10 percent year-on-year in recent months (compared to about 5 percent for the non-financial private sector) (Figure 5).

- Most notably, the cost of credit for Portuguese firms remains extremely high compared to euro area peers. This applies to all market segments, including the more dynamic export sector. While the relatively higher lending rates in Portugal largely reflect differences in sovereign spreads across the region, the ongoing drag on banks' profitability is also playing an important role on credit conditions. In particular, high provisions, low rates on legacy portfolios, and the costly remuneration of the contingent instruments injected by the state are putting pressures on the lending rates applied by banks to new corporate loans, despite the recent decline in deposit rates.
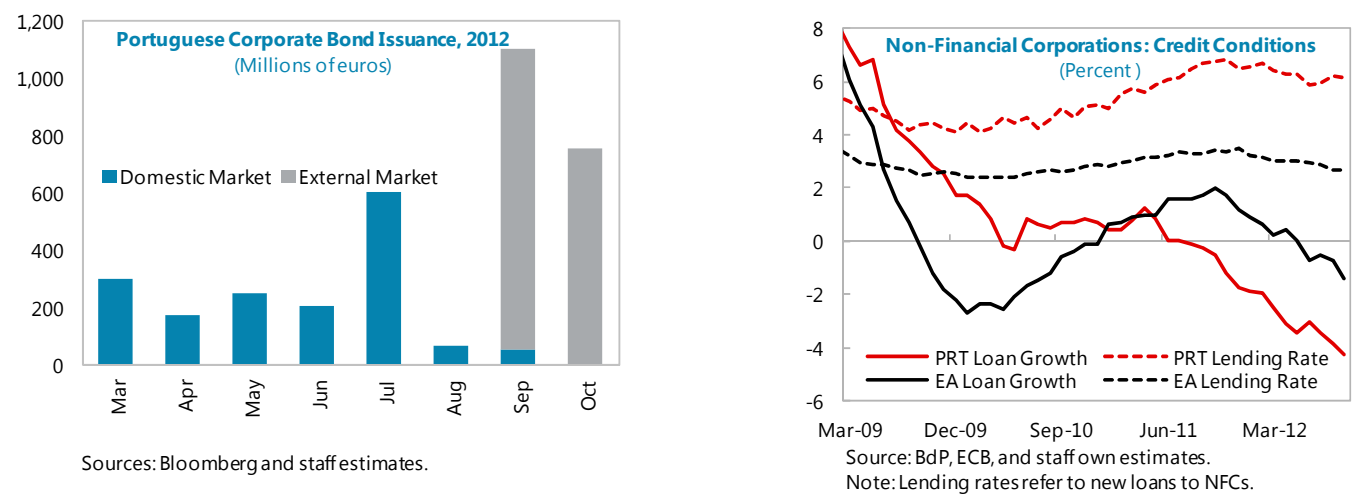

\footnotetext{
${ }^{5}$ The companies, mainly blue chip firms with relatively stable cash flows and/or diversified income sources, were able to raise a total of $€ 1.8$ billion in international markets at rates between $5 \frac{1}{2}$ and $6 \frac{1}{2}$ percent at 5 -year maturities.
} 


\section{B. Policy Discussions}

\section{There were extensive discussions on the principles and modalities of the bank} recapitalization process. All major banks have been successfully recapitalized through private and/or public support, and the recapitalization of one smaller bank, delayed pending completion of its group restructuring, is also being finalized. Consequently, banks are on track to meet the endyear 10 percent Core Tier I requirement under the program. The authorities affirmed that recourse to the public funds being made available under the program for bank recapitalization exercise is being anchored by the following principles: a successful assessment of viability by the Banco de Portugal's (BdP) underpinned by conservative funding and capital plans by the banks; burdensharing with the private sector, as evidenced by successful private placements; and adequate safeguards to protect the interest of taxpayers, including through banks' restructuring plans, in line with EU state aid rules.

\section{Notwithstanding the progress to date, the authorities share staff views on the need for} vigilance. The $B d P$ is continuing with its efforts to ensure the resilience of the banking system. The BdP's new onsite inspections program, focused on asset classes that are more sensitive to current market conditions (e.g. construction, commercial real estate, tourism), highlighted only limited impairment deviations, which are expected to be further mitigated by the impairment reinforcements in the corporate segment already projected by banks for 2012Q4. In addition, the latest quarterly stress test exercise indicated that, following the recent capital augmentation, bank capitalization levels are sufficient to meet the additional 6 percent Core Tier I requirement under the adverse scenario. However, overdue loans by non financial corporations and, to a lesser extent, households are on the rise, calling for continued vigilance. Resources from the Bank Solvency Support Facility (BSSF) remain available to lend support to viable banks should further capital needs arise, although banks are encouraged first and foremost to seek private solutions.

\section{Liquidity buffers are improving, but with too little effect on credit conditions so far.}

Continued Eurosystem support at longer maturities is playing a critical role in providing the necessary liquidity to the banking sector. Banks have successfully mobilized new collateral, raising their liquidity buffers to over $€ 25$ billion (more than six months of their refinancing needs). Nevertheless, in view of Portugal's still tight credit conditions, continued pragmatism by the ECB to favor a gradual and orderly deleveraging process remains critical. In particular, further clarity on Eurosystem's non-standard measures-including on the collateral rules for access to refinancing operations and the eligibility criteria for the newly announced Outright Monetary Transactions (OMT) operations-could be beneficial in removing any

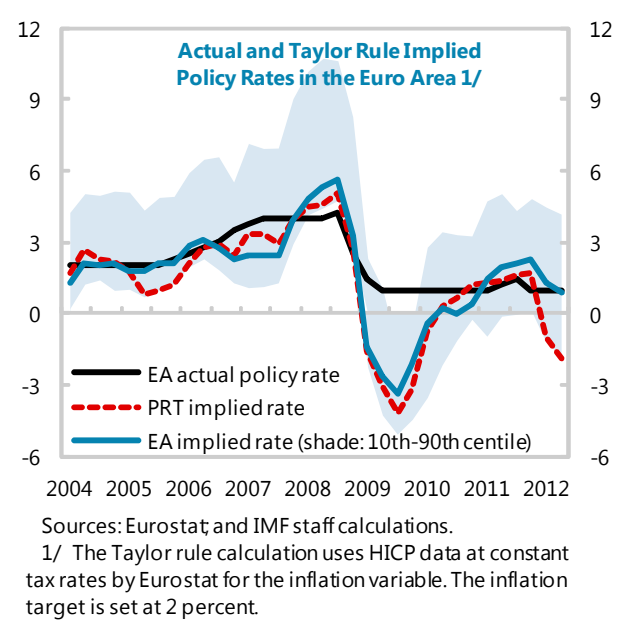
0 3

200420052006200720082009201020112012

The Taylor rule calculation uses HICP data at constant target is set at 2 percent uncertainty weighing on banks' credit decisions and restoring a well-functioning monetary policy transmission in the Euro area. 


\section{The authorities' have stepped-up their efforts to facilitate an orderly deleveraging process.}

- Building on their initial proposal on alternative funding options for the corporate sector (see $5^{\text {th }}$ Review Staff Report), the Ministry of Finance, in collaboration with the BdP and other stakeholders, is prioritizing the development of initiatives aimed at promoting access to funding by SMEs (MEFP आ14). These include measures to promote SMEs' access to capital markets through pooling of debt instruments, notably commercial paper; the rationalization of existing government initiatives to support credit and investment in the more innovative segments of the economy; efforts to support upgrading and sharing of information on SMEs by the private sector (see SI Chapter III). Nevertheless, pending more detailed plans, staff stressed the need to avoid any additional fiscal burden or risks.

- Moreover, given the ongoing concerns on local funding and lending conditions in Portugal, the authorities intend to continue consultation with the European Commission on the rate of remuneration of the contingent instruments used for recapitalization purposes.

- As part of their efforts to promote an orderly corporate balance-sheet adjustment, the authorities are closely monitoring the effectiveness of the newly introduced corporate debt restructuring toolkit. In particular, efforts are ongoing to ensure early restructuring by viable firms experiencing financial difficulties, including by promoting effective coordination with the tax authorities. The authorities are coordinating with banks to assess the potential impact and mitigate risks associated with the implementation of recently approved measures to facilitate household debt restructuring (including mortgages).

\section{The mission also took stock of the ongoing progress of enhancing the bank}

recapitalization and resolution frameworks. Forthcoming amendments seek to allow the state to exercise control over an institution (structural benchmark). In addition, amendments will provide for a mandatory recapitalization process using public funds when an institution's capital falls below the minimum level required and it either does not present a recapitalization plan or does not amend such plan in accordance with feedback from the BdP (MEFP \18). Moreover, as part of the ongoing authorities' efforts to strengthen the early intervention and resolution framework, the supervisory notices on recovery plans and bridge banks have been issued and the regulation governing the organization and operation of the resolution fund has come into force. The authorities continue to work on the legislation relating to the banks' contributions to the resolution fund and the supervisory notice on resolution plans.

\section{BOOSTING COMPETITIVENESS AND GROWTH}

\section{A. Recent Structural Developments}

\section{Labor and product market reforms have continued to advance in recent months:}

- The authorities have made further progress in deploying Active Labor Market Policies. The objective is to improve the employability of the young and disadvantaged categories and ease 
labor market mismatches (see $4^{\text {th }}$ review staff report). Continuous progress is being made in broadening the reach of Vida Ativa, a new targeted training initiative, and improving the role of public employment services. On the education front, efforts are concentrated on improving the quality of secondary education and vocational training.

- Steps are being taken to foster competition and reduce excessive licensing. A framework law for regulation is under preparation. It will aim at guaranteeing the independence of the various sectoral regulators, including by strengthening their financial, administrative and management autonomy. Initiatives to tackle excessive licensing procedures, regulations and other administrative burdens-which are impeding the establishment, operation, and expansion of firms-are moving forward.

- Reforms to boost price competitiveness in ports are advancing. The Port Law amending the traditionally highly protected port work regime was passed by Parliament in first reading. It aims at lowering wage costs substantially and facilitating a more flexible use of labor. The authorities have reduced fees on port use (TUP-Carga) by 10 percent.

25. Reforms to improve the efficiency of the judicial system have progressed well. The authorities have taken steps to further resolve the backlogged enforcement cases including by adopting a decree law for a set of urgent measures designed to combat the court case backlog. The two end-November 2012 structural benchmarks - the new Code of Civil Procedure to speed up the court procedures and the implementation of the judicial roadmap to streamline the court structure-were met (see Box 1). Progress has also been achieved in the area of the enforcement agents' framework in terms of an overhaul to the fee system that incentivizes enforcement and the framework for supervision and monitoring (MEFP \25).

\section{B. Policy Discussions}

\section{The mission has reached understandings on steps to further enhance labor market}

flexibility. Significant measures have already been adopted over the past year to improve the functioning of the labor market, including the recent reform of wage bargaining to ensure wages better reflect heterogeneous firm-level conditions. The government agreed to further lower severance payments to 12 days per year of service (MEFP $\{21$ ), bringing them in line with relevant comparators in the European Union-a draft Law to this effect is to be submitted to Parliament in December. Under the old regime, severance pay was among the highest in advanced countries, even following the reductions introduced last year.

\section{Staff also discussed follow-up actions to the ongoing product market reforms}

(MEFP \22). In particular, while the framework law for regulation is being prepared, the authorities are amending the statutes of the electricity regulator (ERSE) to give it the appropriate powers, independence, and autonomy ahead of full market liberalization in January 2013. Regarding the functioning of ports, another 10-percent cut in ports user fees will be made effective in January. In addition, to ensure the effective transmission of lower unit labor costs to end-users of port services 


\section{Box 1. Progress in Judicial Reform}

Two key judicial reform projects (i.e., the new Code of Civil Procedure and the new Judicial Organization Law to implement the judicial roadmap) have reached a major milestone with the submission to Parliament of two draft laws (end-November 2012 structural benchmarks). This constitutes the first comprehensive reform in these areas in almost a century and concludes a process of intense stakeholder consultation lasting more than a year. The reforms, which are of the medium to long-term nature, seek to improve the efficiency of the judicial system.

The new draft Code of Civil Procedure aims at expediting the civil and enforcement process. The Code enables conciliation and mediation throughout the different stages of the civil process, strengthens the powers of the judge to expedite the civil process, focuses the civil process on substance rather than form, reduces appeal and considerably expedites enforcement procedures. The Code includes many elements of a modern civil process consistent with international best practices.

The draft Judicial Organization Law focuses the judicial organization on flexibility, specialization, and concentration. The law strengthens the personnel flexibility in allocating resources across the country in terms of judges, courts, and courthouses, increases specialization within the judiciary, fosters a better management of courts including through centralized management and concentration, and enables the establishment of time management tools. As a result, the court system will be trimmed significantly.

Both law reform projects need to be adopted by Parliament and are scheduled to enter into force by early 2014. The authorities have also started to focus their efforts to ensure a proper implementation of these new laws once approved by Parliament.

following adoption of the Ports Law, the government will encourage price reductions under existing contracts, revise incentives for port operators by adopting a new performance-based model for future concessions, and encourage entry of new operators.

28. The mission also initiated discussions on ways to make the corporate income tax (CIT) system more conducive to investment and competitiveness. With the policy tool to boost investment and growth highly constrained, staff welcomed the authorities' initiative to review the effectiveness of the existing CIT model. The objective is to assess the competitiveness of the Portuguese corporate income tax system in comparison to peers, and prepare a comprehensive reform aimed at making Portugal a more attractive investment destination (MEFP \5). As part of this exercise, the authorities will analyze the current incentives schemes and work on proposals to enhance their effectiveness, with a view to encouraging the tradable and high value-added sectors, consistent with EU competition rules. The results of this analysis will be discussed during the 7th review.

\section{FINANCING AND RISKS}

29. Conditions in sovereign debt markets have been strong of late. Following the successful bond exchange in early October, and playing off a more benign market environment in the wake of the ECB's policy pronouncements and the recent agreement at the European level to unlock further additional assistance to Greece, spreads have fallen significantly. Secondary market yields on 10year bonds at close to 7 percent-broadly in line with the market re-access interest rate assumed in staff's DSA —represent a substantial step towards sustainable levels. Concerns remain that the rally 
may reflect relatively transient factors, particularly in the wake of the announcement of OMT, while a critical mass of interest from longer-term investors would be needed for lower yields to endure.

Demand for Treasury bills remains solid, with yields stabilizing at low levels, and average maturities rising. These more favorable market conditions also facilitated the international corporate issuance noted above.
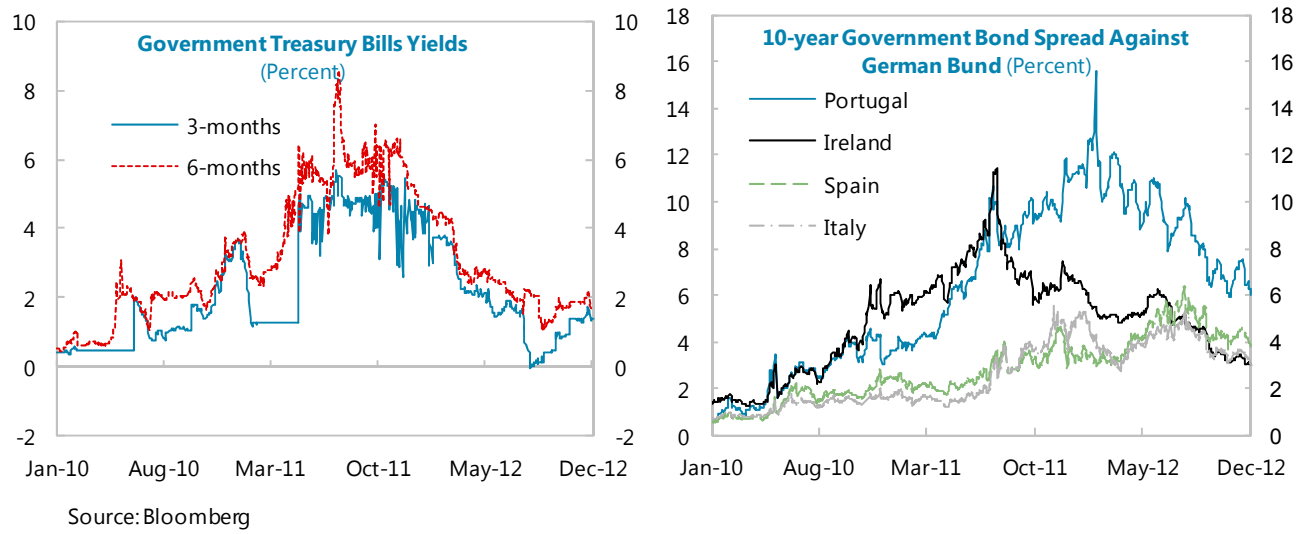

\section{Under these conditions, the authorities' strategy for a gradual return to markets}

remains viable. The authorities are confident that a good cash management strategy will be sufficient to cover needs while access is gradually restored within the current program resource envelope. Specific plans comprise exploiting scope for further Treasury bill issuance, stopping outflows from retail savings instruments issued by the state through offering higher rates of return (this strategy is already yielding results), and seeking to ensure the roll-over of medium-term instruments where possible. The authorities are actively engaging with potential investors, including through road-shows, with a view to issuing debt at two- or three-year tenors when market conditions allow.

31. Against this backdrop, exceptional access remains justified. Notwithstanding improved market conditions, exceptional access under the program remains critical to address Portugal's funding needs. While public debt is assessed to be sustainable over the medium term, sustainability cannot be asserted with high probability. Nonetheless, systemic risk from contagion to other vulnerable Euro Area countries should Portugal fail to fully service its debts justifies exceptional access. Regaining market access within the period that Fund resources are outstanding is feasible, though risks of delays remain. Commitments by Euro Area leaders to provide resources adequate to meet needs until Portugal can regain full market access, as long as the program remains on track, give assurances that financing will be available to repay the Fund. Implementation capacity and prospects for program success remain reasonably strong, given the good track record to date and sufficient political support, including through the large parliamentary majority of the governing coalition.

32. Capacity to repay the Fund remains adequate. The Fund's exposure to Portugal rises to substantial levels, reaching 17 percent of GDP in 2014, with debt service expected to peak in 2018, 
at 5.9 percent of exports of goods and services, or 2.8 percent of GDP. Export strength has partially compensated the increased burden on the economy from Euro weakness, and downward revisions to nominal GDP. Despite fiscal and political setbacks, program implementation capacity remains strong, and the rapid closure of the external imbalances also provides assurance that adequate resources will be available to repay the Fund.

33. Downside risks to the attainment of the program's objectives remain high, and would require a prompt policy response. In particular, the materialization of downside risks to the macro-fiscal outlook noted above-see also Article IV report for a more detailed presentation of medium-term risks to the adjustment process-may require prompt implementation of corrective measures to preserve the achievements to date in strengthening confidence. Should, for example, some of parts of the 2013 Budget be challenged on constitutional grounds, it will be important to rapidly enact offsetting measures to keep the fiscal program on track. On the financing front, renewed stress in euro area financial markets or materialization of fiscal risks could further delay market re-access, and room for maneuver is limited in view of the significant medium-term financing needs.

\section{STAFF APPRAISAL}

34. The authorities continue to maintain a strong policy and reform effort. Reflecting this, fiscal adjustment is advancing and the external position continues to improve at a faster pace than expected. A significant proportion of the imbalances that tipped the economy into crisis have now been unwound. Sovereign yields have continued to decline, although also reflecting easing market conditions at the euro area level.

35. All the same, the reduction of imbalances entails considerable sacrifices in the form of rising unemployment and lower disposable incomes. The social and political climate is markedly more difficult, with resistance to adjustment policies and reforms testing the government's resolve. This has in turn engendered considerable uncertainty and is weighing on confidence. While an economic turnaround is still envisaged to begin in the course of next year, further adjustment needs and the recession in the euro area represent significant risks to the growth outlook.

\section{With few easy alternatives available, sustaining the adjustment effort is unavoidable.}

The financing constraint remains binding and public and private sector debt levels are very high. In this context, there are no easy alternatives to further adjustment to bring public finances in order and gradual deleveraging to improve private sector balance sheets. And within the constraints of the monetary union, fostering a more competitive economy by consistently implementing difficult structural reforms is the only way to underpin sustainable external adjustment and strong growth. Significant progress has been achieved on all of these fronts, but consolidating the gains to date requires determination to advance toward the program objectives.

37. Tight budget implementation is critical, and the authorities should stand ready to take further action to ensure the fiscal program remains on track. The government remains committed to achieving the deficit target of 5 percent of GDP in 2012 and a deficit of 4.5 percent of 
GDP in 2013. But with signs of revenue weaknesses already visible, staff welcomes the government's pledge to identify contingency measures. This is particularly important as risks to the macro-fiscal outlook remain significant. Continued efforts in consistently implementing the law on expenditure commitment controls, further strengthening revenue administration, and tighter control over SOEs and PPPs will also be important to limit risks to budget execution. If some of the 2013 budget provisions are revoked by the Constitutional Court, alternative measures should also be promptly enacted.

\section{Staff strongly supports the authorities' objective to rebalance the adjustment effort} toward expenditure going forward. A tax-to-GDP ratio already in line with peers, heavy reliance on raising new revenues in 2013 , and disappointing revenue performance so far put a high premium on completing the planned expenditure review. Early identification of specific spending reform options for the next few years would help bolster confidence. But because Portugal's spending is heavily concentrated on sensitive outlays such as social transfers and public wages, it will be essential to build as broad a consensus as possible behind the required reforms.

\section{Risks to financial stability need to be monitored vigilantly. The recapitalization of the} banking sector and the strengthening of banking supervision and resolution frameworks are advancing. Liquidity in the banking system, underpinned by stable deposits, continues to benefit from exceptional support from the Eurosystem. Deleveraging in the banking system has proceeded apace, although access to credit at reasonable conditions remains difficult for exporting companies and small and medium-sized enterprises (SMEs). Staff welcomes measures to ensure adequate funding, including initiatives to improve information-sharing on SMEs and facilitate their access to capital markets.

\section{Fostering a more competitive economy is imperative. Progress on labor and product} market reforms as well as in the judiciary area should go a long way in making the economy more efficient. However, it remains unclear whether reforms to date are sufficient to address the large external competitiveness gap or will engender an adequately strong supply response to avoid a prolonged demand-driven slump. Staff urges the authorities to continue exploring alternative policy options to catalyze significant reductions in production costs and compress excessive non-tradable sector profit margins. This entails rigorous enforcement of competition laws and regulations as well as identifying and tackling more decisively any explicit and implicit policies that limit market entry and hinder competition. The planned comprehensive reform of the corporate income tax could also help foster investment and competitiveness, while cost reductions for ports will ensure a more competitive framework in this part of the transport infrastructure that is critical for exports.

\section{The success of the program also depends critically on continued external support and} successful crisis policies at the euro-area level. Considerable uncertainties persist and Portugal remains vulnerable to shocks stemming from other euro area countries or policy failures at the regional level. While implementation of the authorities' adjustment program is the key for mending Portugal's deep-seated economic problems, these domestic efforts need to be complemented by institutional reforms at euro-area level to clear a path toward a durable return to market financing. The commitment by European leaders to support Portugal until market access is restored, as long as 
the authorities persevere with strict program implementation, continues to provide a valuable financing assurance. Recourse to the ECB's Outright Monetary Transactions would help address credit market segmentation and restore an appropriate monetary policy transmission.

42. Staff recommends completion of the sixth review and the granting of waivers of applicability. 
Table 1. Portugal: General Government Financing Requirements and Sources 1/ (Billion of euros)

\begin{tabular}{|c|c|c|c|c|c|c|c|c|c|}
\hline & 2009 & 2010 & 2011 & 2012 & 2013 & 2014 & 2015 & 2016 & 2017 \\
\hline Gross borrowing need & 45.3 & 58.4 & 59.3 & 59.5 & 38.1 & 36.7 & 33.7 & 40.2 & 32.3 \\
\hline Overall balance & 17.1 & 17.0 & 7.5 & 8.3 & 7.5 & 4.3 & 3.5 & 3.2 & 3.3 \\
\hline Amortization & 26.1 & 31.0 & 40.7 & 34.9 & 28.1 & 32.6 & 31.1 & 38.4 & 29.5 \\
\hline$M \& L T$ & 6.5 & 7.7 & 12.8 & 15.1 & 10.9 & 16.3 & 12.5 & 12.1 & 9.3 \\
\hline Residents & 0.9 & 0.7 & 3.9 & 8.8 & 6.0 & 7.6 & 5.6 & 5.9 & 4.7 \\
\hline Of which within general government & 0.1 & 0.0 & 0.4 & 2.2 & 1.2 & 1.7 & 0.8 & 0.7 & 0.6 \\
\hline Non-residents & 5.6 & 7.1 & 8.9 & 6.3 & 4.9 & 8.7 & 7.0 & 6.1 & 4.5 \\
\hline ST & 19.6 & 23.3 & 27.9 & 18.8 & 17.2 & 16.2 & 16.2 & 16.2 & 16.2 \\
\hline Residents & 5.6 & 6.4 & 16.9 & 17.0 & 16.1 & 12.8 & 10.7 & 8.6 & 8.6 \\
\hline Of which within general government & 0.9 & 1.1 & 3.3 & 4.7 & 1.4 & $\ldots$ & $\ldots$ & $\ldots$ & $\ldots$ \\
\hline Non-residents & 14.0 & 16.9 & 11.0 & 1.8 & 1.1 & 3.5 & 5.5 & 7.6 & 7.6 \\
\hline EU and IMF & 0.0 & 0.0 & 0.0 & 1.0 & 0.0 & 0.0 & 2.3 & 10.1 & 4.0 \\
\hline Other 2/ & 3.6 & 11.4 & 17.4 & 25.5 & 2.5 & -0.1 & -0.8 & -1.4 & -0.5 \\
\hline Of which within general government & 3.1 & 6.3 & 10.8 & 12.7 & $\ldots$ & $\ldots$ & $\ldots$ & $\ldots$ & $\ldots$ \\
\hline Other (net) $2 /$ & 2.1 & 10.4 & 11.0 & 16.3 & 2.5 & -0.1 & -0.8 & -1.4 & -0.5 \\
\hline Of which within general government $3 /$ & 2.1 & 4.6 & 3.9 & 5.0 & $\ldots$ & $\ldots$ & $\ldots$ & $\ldots$ & $\ldots$ \\
\hline Gross financing sources & 45.3 & 58.4 & 23.9 & 30.9 & 27.9 & 28.7 & 33.7 & 40.2 & 32.3 \\
\hline Privatization receipts & 0.0 & 0.7 & 0.6 & 2.2 & 2.0 & 0.0 & 0.0 & 0.0 & 0.0 \\
\hline Market access & 44.0 & 59.0 & 36.8 & 24.3 & 23.0 & 28.7 & 33.7 & 40.2 & 32.3 \\
\hline M\&LT & 20.8 & 31.0 & 18.0 & 7.0 & 6.7 & 12.4 & 17.5 & 23.9 & 16.1 \\
\hline Residents & 7.3 & 15.9 & 13.7 & 6.2 & 3.4 & 5.5 & 6.4 & 8.5 & 6.3 \\
\hline Of which from general government & 1.2 & 3.0 & 6.1 & 3.0 & $\ldots$ & $\ldots$ & $\ldots$ & $\ldots$ & $\ldots$ \\
\hline Non-residents & 13.5 & 15.1 & 4.3 & 0.9 & 3.3 & 6.9 & 11.1 & 15.4 & 9.8 \\
\hline ST & 23.3 & 27.9 & 18.8 & 17.2 & 16.2 & 16.2 & 16.2 & 16.2 & 16.2 \\
\hline Residents & 6.4 & 16.9 & 17.0 & 16.1 & 12.8 & 10.7 & 8.6 & 8.6 & 8.6 \\
\hline Of which from general government & 1.1 & 3.3 & 4.7 & $\ldots$ & $\ldots$ & $\ldots$ & $\ldots$ & $\ldots$ & $\ldots$ \\
\hline Non-residents & 16.9 & 11.0 & 1.8 & 1.1 & 3.5 & 5.5 & 7.6 & 7.6 & 7.6 \\
\hline Use of deposits 4/ & 1.3 & -1.3 & -13.5 & 4.5 & 3.0 & 0.0 & 0.0 & 0.0 & 0.0 \\
\hline Of which intra-government $3 /$ & 0.8 & -0.6 & -3.2 & 2.9 & $\ldots$ & $\ldots$ & $\ldots$ & $\ldots$ & $\ldots$ \\
\hline Financing under the program $5 /$ & 0.0 & 0.0 & 35.3 & 28.5 & 10.1 & 8.1 & 0.0 & 0.0 & 0.0 \\
\hline European Union & $\ldots$ & $\ldots$ & 22.2 & 20.3 & 6.5 & 5.2 & $\ldots$ & $\ldots$ & $\ldots$ \\
\hline IMF & $\ldots$ & $\ldots$ & 13.1 & 8.2 & 3.6 & 2.9 & $\ldots$ & $\ldots$ & $\ldots$ \\
\hline Net placement (market access-amortization) & 17.9 & 28.0 & -3.9 & -10.6 & -5.1 & -3.9 & 2.7 & 1.8 & 2.8 \\
\hline Residents & 7.1 & 25.8 & 9.9 & -6.0 & -6.0 & -4.2 & -1.2 & 2.6 & 1.6 \\
\hline M\&LT & 6.3 & 15.3 & 9.8 & -2.7 & -2.6 & -2.1 & 0.9 & 2.6 & 1.6 \\
\hline ST (net increase) & 0.8 & 10.5 & 0.1 & -3.4 & -3.4 & -2.1 & -2.1 & 0.0 & 0.0 \\
\hline Non-residents & 10.9 & 2.2 & -13.8 & -3.0 & 0.8 & 0.3 & 6.2 & 9.2 & 5.3 \\
\hline M\&LT & 7.9 & 8.0 & -4.6 & -5.4 & -1.5 & -1.8 & 4.1 & 9.2 & 5.3 \\
\hline ST (net increase) & 2.9 & -5.9 & -9.2 & 2.4 & 2.4 & 2.1 & 2.1 & 0.0 & 0.0 \\
\hline
\end{tabular}

Source: Portuguese authorities and Fund staff estimates.

1/ The coverage of this table has been expanded to fully reflect all general government (including local and regional governments and SOES) financing operations. However, data are on a non-consolidated basis (with intra-government flows presented where available). On a consolidated basis, they are smaller, by the amount of intra-government transactions.

2/ Includes use of Bank Solvency Support Facility and other net financial transactions, net financing from retail government securities programs, as well as adjustments for cash-accrual differences and consistency between annual projections and preliminary quarterly accounts.

3/ Values for 2012 are projections based on estimates for Q1-Q3.

4/ Changes in government deposits (including deposits in BSSF).

5/ Changes in IMF disbursements compared to the initial programmed amounts reflect EUR/SDR exchange rate variations. Program financing from the EU includes the EUR 1.1 billion EFSF pre-paid margin (2011) and the roll-over of a EUR 1 billion short-term loan (2012). 
Table 2. Portugal: External Financing Requirements and Sources, 2009-17

(Billion of euros)

\begin{tabular}{|c|c|c|c|c|c|c|c|c|c|}
\hline & 2009 & 2010 & 2011 & 2012 & 2013 & 2014 & 2015 & 2016 & 2017 \\
\hline GROSS FINANCING REQUIREMENTS & 170.3 & 187.0 & 210.8 & 180.7 & 173.7 & 180.6 & 181.4 & 159.3 & 151.9 \\
\hline Current account deficit & 18.4 & 17.2 & 11.0 & 4.2 & 1.9 & 1.8 & 0.8 & -0.2 & -0.3 \\
\hline Medium- and long-term debt amortization & 23.0 & 30.9 & 30.8 & 29.3 & 28.4 & 34.7 & 33.5 & 14.5 & 18.8 \\
\hline Public sector & 5.6 & 7.1 & 8.9 & 6.3 & 4.9 & 8.7 & 7.0 & 6.1 & 4.5 \\
\hline Banks & 14.4 & 20.6 & 17.9 & 19.1 & 15.9 & 18.7 & 18.4 & 4.3 & 11.3 \\
\hline Other private & 3.0 & 3.3 & 4.1 & 3.9 & 7.6 & 7.3 & 8.1 & 4.0 & 2.9 \\
\hline Short-term debt amortization & 129.0 & 138.9 & 168.9 & 147.2 & 143.4 & 144.1 & 144.9 & 134.9 & 129.4 \\
\hline Public sector & 32.7 & 40.3 & 71.0 & 63.6 & 73.8 & 74.8 & 74.8 & 60.0 & 46.2 \\
\hline Central Bank & 19.0 & 23.4 & 59.9 & 61.0 & 72.7 & 71.3 & 69.2 & 52.4 & 38.6 \\
\hline General government and SOEs & 13.7 & 16.9 & 11.1 & 2.7 & 1.1 & 3.5 & 5.5 & 7.6 & 7.6 \\
\hline Banks & 79.0 & 79.5 & 76.6 & 57.4 & 51.3 & 52.8 & 54.4 & 56.0 & 57.7 \\
\hline Other private & 17.3 & 19.1 & 21.3 & 26.3 & 18.4 & 16.5 & 15.7 & 18.9 & 25.5 \\
\hline EU and IMF 1/ & 0.0 & 0.0 & 0.0 & 0.0 & 0.0 & 0.0 & 2.3 & 10.1 & 4.0 \\
\hline SOURCES OF FINANCING & 170.3 & 187.0 & 176.8 & 153.0 & 163.5 & 172.5 & 181.4 & 159.3 & 151.9 \\
\hline Capital account (net) & 1.4 & 1.9 & 2.1 & 4.0 & 2.4 & 2.4 & 2.4 & 2.4 & 2.4 \\
\hline Foreign direct investment (net) & 1.4 & 7.7 & -1.7 & 3.8 & -0.5 & -1.1 & -1.2 & -1.4 & -1.5 \\
\hline Inward & 1.9 & 2.0 & 7.4 & 10.4 & 3.5 & 3.1 & 3.1 & 3.2 & 3.2 \\
\hline New borrowing and debt rollover & 183.7 & 196.1 & 161.2 & 151.2 & 166.9 & 173.5 & 176.0 & 156.1 & 152.2 \\
\hline Medium and long-term borrowing & 44.8 & 27.3 & 14.9 & 7.8 & 22.8 & 28.7 & 41.1 & 26.8 & 28.0 \\
\hline General Government & 13.5 & 15.1 & 4.3 & 0.9 & 3.3 & 6.9 & 11.1 & 15.4 & 9.8 \\
\hline Banks & 26.0 & 5.8 & 2.8 & 3.8 & 13.4 & 15.1 & 20.4 & 5.9 & 14.7 \\
\hline Other private & 5.3 & 6.4 & 7.7 & 3.1 & 6.1 & 6.6 & 9.7 & 5.4 & 3.5 \\
\hline Short-term borrowing & 138.9 & 168.8 & 146.4 & 143.4 & 144.1 & 144.9 & 134.9 & 129.4 & 124.2 \\
\hline Public sector & 40.3 & 71.0 & 62.8 & 73.8 & 74.8 & 74.8 & 60.0 & 46.2 & 39.3 \\
\hline Central Bank & 23.4 & 59.9 & 61.0 & 72.7 & 71.3 & 69.2 & 52.4 & 38.6 & 31.7 \\
\hline General government & 16.9 & 11.0 & 1.8 & 1.1 & 3.5 & 5.5 & 7.6 & 7.6 & 7.6 \\
\hline Banks & 79.5 & 76.6 & 57.4 & 51.3 & 52.8 & 54.4 & 56.0 & 57.7 & 59.4 \\
\hline Other private & 19.1 & 21.3 & 26.3 & 18.4 & 16.5 & 15.7 & 18.9 & 25.5 & 25.5 \\
\hline Other (includes asset operations) & -16.1 & -18.7 & 15.1 & -6.0 & -5.2 & -2.3 & 4.3 & 2.2 & -1.2 \\
\hline Of which: Net errors and omissions & -0.5 & -0.3 & -0.6 & 0.0 & 0.0 & 0.0 & 0.0 & 0.0 & 0.0 \\
\hline FINANCING GAP & 0.0 & 0.0 & 33.9 & 27.7 & 10.2 & 8.1 & 0.0 & 0.0 & 0.0 \\
\hline European Union ( $2 / 3$ of total) $1 /$ & $\ldots$ & $\ldots$ & 20.9 & 19.4 & 6.5 & 5.2 & $\ldots$ & $\ldots$ & $\ldots$ \\
\hline IMF (1/3 of total) & $\ldots$ & $\ldots$ & 13.1 & 8.3 & 3.6 & 2.9 & $\ldots$ & $\ldots$ & $\ldots$ \\
\hline \multicolumn{10}{|l|}{ ROLLOVER RATES } \\
\hline General government & 157.7 & 109.2 & 30.5 & 22.2 & 113.8 & 102.3 & 149.5 & 167.1 & 143.3 \\
\hline Private & 114.2 & 89.9 & 78.6 & 71.8 & 95.3 & 96.3 & 108.6 & 113.5 & 105.8 \\
\hline Banks & 113.0 & 82.3 & 63.7 & 71.9 & 98.5 & 97.3 & 104.9 & 105.4 & 107.4 \\
\hline Other private & 119.7 & 124.0 & 134.0 & 71.3 & 87.1 & 93.5 & 120.0 & 135.0 & 102.1 \\
\hline
\end{tabular}




\begin{tabular}{|c|c|c|c|c|}
\hline \multirow{2}{*}{ Review } & \multirow{2}{*}{ Review date } & \multirow{2}{*}{ Action } & \multicolumn{2}{|c|}{ Purchase } \\
\hline & & & In millions of SDRs & in percent of quota \\
\hline & May 20, 2011 & Board approval of Extended Arrangement & 5,611 & 544.9 \\
\hline First review & September 12, 2011 & Observation of end-June 2011 performance criteria; completion of first review & 3,467 & 336.7 \\
\hline Second review & December 19, 2011 & Observation of end-September 2011 performance criteria; completion of second review & 2,425 & 235.5 \\
\hline Third review & April 4, 2012 & Observation of end-December 2011 performance criteria; completion of third review & 4,443 & 431.5 \\
\hline Fourth review & July 16, 2012 & Observation of end-March 2012 performance criteria; completion of fourth review & 1,197 & 116.2 \\
\hline Fifth review & October 24, 2012 & Observation of end-June 2012 performance criteria; completion of fifth review & 1,259 & 122.3 \\
\hline Sixth review & January 15, 2013 & Observation of end-September 2012 performance criteria; completion of sixth review ${ }^{1 /}$ & 724 & 70.3 \\
\hline Seventh review & April 15, 2013 & Observation of end-December 2012 performance criteria; completion of seventh review & 574 & 55.7 \\
\hline Eighth review & June 15, 2013 & Observation of end-March 2013 performance criteria; completion of eighth review & 806 & 78.3 \\
\hline Ninth review & September 15, 2013 & Observation of end-June 2013 performance criteria; completion of ninth review & 873 & 84.8 \\
\hline Tenth review & December 15, 2013 & Observation of end-September 2013 performance criteria; completion of tenth review & 803 & 78.0 \\
\hline Eleventh review & March 15, 2014 & Observation of end-December 2013 performance criteria; completion of eleventh review & 760 & 73.8 \\
\hline Twelfth review & May 15, 2014 & Observation of end-March 2014 performance criteria; completion of twelfth review & 800 & 77.7 \\
\hline Total & & & 23,742 & $2,305.7$ \\
\hline
\end{tabular}




\begin{tabular}{|c|c|c|c|c|c|c|c|c|c|}
\hline \multicolumn{10}{|c|}{$\begin{array}{l}\text { Table 4. Portugal: Indicators of Fund Credit } \\
\text { (Millions of euros, unless otherwise specified) }\end{array}$} \\
\hline & 2011 & 2012 & 2013 & 2014 & 2015 & 2016 & 2017 & 2018 & 2019 \\
\hline Disbursements & 13,052 & 8,200 & 3,633 & 2,890 & $\ldots$ & $\ldots$ & $\ldots$ & $\ldots$ & $\ldots$ \\
\hline (in percent of quota) & 1,117 & 670 & 289 & 229 & $\ldots$ & $\ldots$ & $\ldots$ & $\ldots$ & $\ldots$ \\
\hline \multicolumn{10}{|c|}{ (Projected debt service to the Fund, based on existing and prospective drawings) } \\
\hline Total & 14 & 153 & 686 & 910 & 1,650 & 3,849 & 4,908 & 5,459 & 5,423 \\
\hline Interest and charges & 14 & 153 & 686 & 910 & 1,075 & 1,032 & 901 & 729 & 533 \\
\hline Repayments & 0 & 0 & 0 & 0 & 574 & 2,818 & 4,007 & 4,729 & 4,890 \\
\hline \multicolumn{10}{|l|}{ Total debt service, in percent of } \\
\hline Exports of goods and services & 0.0 & 0.2 & 1.0 & 1.3 & 2.2 & 4.7 & 5.7 & 5.9 & 5.6 \\
\hline GDP & 0.0 & 0.1 & 0.4 & 0.5 & 0.9 & 2.1 & 2.6 & 2.8 & 2.7 \\
\hline \multicolumn{10}{|c|}{ (Projected level of credit outstanding based on existing and prospective drawings) } \\
\hline Outstanding stock & 13,052 & 23,007 & 27,068 & 29,041 & 28,574 & 25,855 & 21,855 & 17,125 & 12,235 \\
\hline in percent of quota & $1,117.1$ & $1,857.4$ & $2,154.2$ & $2,305.7$ & $2,260.3$ & $2,038.2$ & $1,717.4$ & $1,345.8$ & 961.5 \\
\hline in percent of GDP & 7.6 & 13.8 & 16.2 & 17.1 & 16.3 & 14.3 & 11.7 & 8.9 & 6.1 \\
\hline \multicolumn{10}{|c|}{ Memorandum Items (in billions of euros) } \\
\hline Exports of goods and services & 62 & 65 & 68 & 72 & 76 & 81 & 87 & 92 & 98 \\
\hline GDP & 171 & 166 & 167 & 170 & 175 & 181 & 187 & 193 & 199 \\
\hline
\end{tabular}




\section{APPENDIX I. PORTUGAL: LETTER OF INTENT}

Lisbon, December 19, 2012

Ms. Christine Lagarde

Managing Director

International Monetary Fund

Washington, DC 20431

Dear Ms. Lagarde:

1. The attached Memorandum of Economic and Financial Policies (MEFP) describes the progress made in recent months towards the objectives laid out in our program supported by the Extended Arrangement. It also updates previous MEFPs and highlights the policy steps to be taken in the next months.

2. The end-September deficit and debt performance criteria were met and the two endNovember structural benchmarks on the submission to Parliament of the new Code of Civil Procedure and the reform of the court organization were also met.

3. We remain strongly committed to the program's policies and objectives and expect the agreed 5 percent deficit target for 2012 to be achieved. The 2013 budget was approved by the Parliament, including a range of tax and spending measures that should ensure the general government deficit of $4 \frac{1}{2}$ percent of GDP will be achieved next year. To advance with the additional fiscal adjustment that is required in coming years, we have initiated a comprehensive public expenditure review exercise to be completed early in 2013.

4. Consistent with our commitment to implement a multi-year strategic plan to strengthen fiscal discipline, we are intensifying our efforts to prevent the increase in the stock of existing domestic arrears. We are reforming the SOE sector, which has been brought to overall operational balance, as per our commitment, after many years of chronic deficits. We will continue this restructuring effort, and to actively manage their high legacy debt burden. Moreover, the privatization is proceeding as scheduled and we are advancing our strategy to put the PPPs on a sustainable financial path.

5. Our policy efforts to preserve financial stability will continue, as banks are on track to meet the 2012 capital requirements, following the recent capital exercise. Banco de Portugal (BdP) continues on its supervisory effort to ensure adequate recognition of impairment levels, as evidenced by the successful completion of the latest on-site inspection. In addition, the recapitalization and resolution framework will be further strengthened. The Portuguese authorities are preparing a proposal for the setting-up of a mechanism to securitize high-quality mortgage credit with a supranational guarantee. Moreover, we are exploring a new proposal to rationalize and redirect to the most productive segments of the economy existing government initiatives, including the setting up of a revolving mechanism to leverage EU structural funds. Finally, we will also 
continue consultation with the European Commission on the rate of remuneration of financial instruments used for recapitalization purposes. In pursuing this route, we are motivated by concerns on local funding and lending conditions.

6. We have made important advances in many dimensions of our ambitious structural reform agenda, and will continue to press ahead with measures to improve the business environment and help spur investment. Measures to actively promote employment and improve education are being expanded. With the completion of the reduction of severance payments, to be soon submitted to Parliament, we will have reduced the rigidity of labor contracts substantially. A landmark revision of the Ports Work Law in discussion in the Parliament will increase efficiency and help reduce costs for exporters. Going forward, we will continue to pursue a streamlined and more effective licensing and regulatory framework along with a reform in corporate taxation, as part of our strategy to attract more investment and boost competitiveness.

7. On the basis of the strength of the policies defined in this letter, and in light of our performance under the program, we request the completion of the sixth review under the Extended Arrangement, the seventh purchase under the arrangement in the amount of SDR 724 million, as well as a waiver of applicability for the end-December deficit and debt performance criteria.

8. We remain confident that the policies described in the current and previous MEFPs are adequate to achieve the objectives under the program. We stand ready to take additional measures should they be needed to meet the objectives of the economic program and will consult with the IMF, the European Commission, and the ECB, in advance of any necessary revisions to the policies contained in this letter and attached Memorandum.

9. This letter is copied to Messrs. Juncker, Rehn, and Draghi.

Sincerely yours,

/s/

Vítor Gaspar
Minister of State and Finance

\author{
/s/ \\ Carlos da Silva Costa \\ Governor of the Banco de Portugal
}

Attachments: 1. Memorandum of Economic and Financial Policies (MEFP)

2. Technical Memorandum of Understanding (TMU) 


\section{ATTACHMENT I. PORTUGAL: MEMORANDUM OF ECONOMIC AND FINANCIAL POLICIES}

December 19, 2012

1. Activity. The outlook for growth and inflation remains broadly in line with the program framework. In the third quarter of 2012, real GDP contracted by 0.8 percent (over the previous quarter), somewhat smaller than the 1 percent assumed under the baseline. The main drag on growth remains the ongoing private sector deleveraging, ongoing fiscal adjustment, and, in more recent months, the marked slowdown in activity in the euro area. Looking ahead, we expect output to trough in the first half of 2013 followed by a gradual recovery in activity from the third quarter, limiting the contraction in output on average to 1 percent in 2013. The decline in investment is expected to slow down, as the strong export growth of recent quarters is expected to foster some increase in capacity utilization. The current account deficit is projected to continue narrowing from 6.5 percent of GDP last year to under 3 percent in 2012 and under 1 percent in 2013. The employment outlook unfortunately looks set to remain difficult, with projected average unemployment rates of $15 \frac{1}{2}$ percent this year and $16 \frac{1}{2}$ percent in 2013 . Moreover, downside risks to both the output and employment outlook are significant, and avoiding still weaker outcomes will depend greatly on developments in the euro area.

\section{FISCAL POLICY}

2. Budget 2012. Revenue performance has been somewhat weaker than envisaged in recent months. This is explained by macroeconomic developments (continued rebalancing of activity from domestic demand to net exports) and some temporary factors such as an unanticipated increase in tax reimbursements). Tight spending execution is being maintained, ensuring the end-September government cash deficit was met. While there are downside risks, the general government deficit objective of 5 percent of GDP for 2012 should be achieved reflecting our plans to sustain firm spending discipline. This is after the inclusion of revenue from the one-off sale of the ANA concession, which is expected to generate 0.7 percent of GDP. Overall, in 2012, the structural primary deficit is estimated to have improved by some $2 \frac{1}{2}$ percentage points of GDP.

3. Budget 2013. The 2013 budget was approved by Parliament on November 28. It includes a range of tax and spending measures: increases in personal income tax (PIT) rates and introduction of the streamlined PIT structure; increases in property and excise tax collection; changes to the corporate income tax to reduce debt bias; the streamlining of public services, and improved targeting of social transfers (see MEFP for the fifth review for a fuller description). Reflecting the discussions in the Parliament, we have been able to improve the composition of the adjustment, allowing us to reduce the surcharge on personal income tax by from 4 to $3 \frac{1}{2} 2$ percent, offset mainly by spending cuts. Overall, the measures adopted in the budget should ensure that the general government deficit to $4 \frac{1}{2}$ percent of GDP next year is achieved. As customary, we stand ready to take additional measures, if need be, to ensure this deficit objective is met. 
4. Expenditure Review. To underpin the additional fiscal adjustment that is required in coming years, we have initiated a comprehensive public expenditure review exercise-to be discussed at the seventh review - with contributions from a broad range of stakeholders in the Portuguese society. Once the initial assessment is completed, we intend to initiate a consultation with social and political partners to ensure that this review has the broad-based support to reform the role and functions of the Portuguese state. The objective will be to refocus the role of the State in Portugal in order to ensure the sustainability, the effectiveness, and the equity of its social functions. This will allow generating spending savings of about $€ 4$ billion in 2013 and 2014. To this end, this exercise will aim at ensuring better value-for-money from the public sector. Furthermore, a crucial consideration will be to reallocate resources toward growth-friendly spending areas.

5. CIT. In parallel with the expenditure review we are launching a comprehensive reform of our corporate income taxation, so as to make Portugal a more attractive investment destination and boost competitiveness. We will analyze the competitiveness of the Portuguese corporate income tax system in comparison to peers-including its rates, tax expenditures, depreciation, loss-carryover rules, holding regimes, and group taxation rules. In addition, we will reform our tax policy in order to promote the internationalization of Portuguese groups and attract FDI, as well as the effectiveness of existing tax incentives schemes, particularly in tradable and high value-added sectors. The results of this analysis, which will be discussed during the $7^{\text {th }}$ review, will help us devise strategic reform objectives for the CIT system. The 2013 budget foresees the possibility of broadening the scope of existing tax benefits aimed at boosting investment. We will ensure that any new initiative implemented under the budget provisions be fully consistent with our strategic reform objectives as well as EU State Aid rules, while assuring that this reform will be budget neutral.

\section{CONTAINING FISCAL RISKS}

6 Public Financial Management. We are committed to implement our 2013-2015 PFM Strategic Plan in order to strengthen fiscal accountability and transparency, reduce budgetary fragmentation, and build institutional capacity. To this end, we will proceed to transpose the new EU economic and fiscal governance framework by year-end and conduct a review of the Budgetary Framework Law in 2013, streamlining budget procedures. We will intensify our efforts to prevent the underlying increase in the stock of domestic arrears of the health sector, which still reflects commitments in excess of funding. We will work closely with the Autonomous Region of Madeira to ensure that the region's commitment control system is in full compliance with the new commitment control law. We are on track to submit the Regional and Local Finance Laws to Parliament by yearend (structural benchmark).

7. Revenue Administration. We will continue to strengthen our tax compliance strategy and to modernize the revenue administration. In particular, our VAT invoicing reform will enter into force on January 1st, 2013. We will also phase-in a new tax compliance management approach over a three-year period, with the implementation of two pilot projects on key risk sectors - the High Net Wealth Individuals and the Self-employed Professionals-by July 2013. The new approach will be guided by a comprehensive tax compliance report, including a risk analysis by economic sector and 
taxpayer size, to be discussed in the $7^{\text {th }}$ review. We are on track to fully implement the Large Taxpayer Office by year-end (structural benchmark). The streamlining of the revenue administration's local offices will be completed by June 2014, aiming at closing down half of the existing branches. We are accelerating efforts to successfully conclude the property revaluation process and we expect to reach about 4 million properties by year-end. This far-reaching project will be finalized by March 2013. Finally, the tax administration has systematically improved its performance in tax courts' decisions.

8. Public Administration. Our public administration reform is advancing and we will continue to press ahead with the objective to shape a more efficient State. The PREMAC program, which reduced around 27 percent of management positions and 40 percent of administrative units across the central administration, was successfully concluded. The reduction in the number of public employees is projected at 3.5 percent in 2012, well above the 2 percent program target. Looking ahead, we remain committed to continue streamlining excess employment in a targeted way. We will also improve training and qualification of public employees and reinforce human resources management policies across all administrations. In this context, labor and social protection regimes will converge to private sector rules, increasing productivity and improving the quality of public services.

9. State-Owned Enterprises. We continue to make progress in restructuring the SOE sector. We have achieved our objective of restoring operational balance to the sector as a whole before the end of 2012. Completion of cost cutting programs at firms still in deficit, consolidation of functions at merged firms, voluntary redundancies and efforts to raise non-core revenues will ensure this significant turnaround is sustained and deepened in 2013. We will continue to actively manage the high legacy debt burdens of these companies. Some small SOEs with non-essential functions are being wound down, and we are developing a strategy to sell or rent non-vital real estate assets.

10. Privatization. The privatization program remains on-track. We will accept final bids for the airport concession company ANA and the airline TAP soon, successfully meeting our development and financial objectives, with financial completion expected early in 2013. With the completion of this sale, 80 percent of the program objective to raise $€ 5$ billion will have been met. We will launch the privatization process for the postal company CTT in the second quarter of 2013, with a view to completing the process by the end of the year. The sale of the rail cargo firm CP Carga will be launched early in 2013, to be completed in the second or third quarter. A strategic plan for the water sector, which envisages the sale or concession of the waste management business, is being prepared.

11. Public-Private Partnerships. We are advancing our strategy to put the PPPs financial model on a sustainable path. The first stage of the road PPPs strategy has been concluded and is expected to lead to savings in excess of $€ 1$ billion, in NPV terms, starting in 2014 . This will be reached by reducing maintenance costs of the sub-concessions contracts. However, a sustainable solution to the Portuguese road model will only be achieved after the completion of the ongoing second phase, which includes a gradual change in the risk matrix of some PPP projects, resulting in a significant 
reduction in the availability payments by the State starting in March 2013. The newly-created PPP Unit will technically support and monitor all phases of the renegotiation process.

\section{SAFEGUARDING FINANCIAL STABILITY}

12. Credit and Funding Conditions. Reflecting both demand and supply factors, aggregate credit continues to decline. But within this overall picture, there are large differences between domestic and foreign sources of financing and among firms. Credit to large firms has continued to expand, supported by successful bond issuances in both the domestic and international markets, whereas loans by domestic banks to SMEs exposed to the non-tradable sector continued to contract significantly. Demand for credit by firms remains conditioned by the need to reduce the large debt burdens they face. The supply of credit is being affected inter alia by the banking system's need to move to a sustainable business model. In particular, very low rates on the legacy mortgage portfolios are proving a drag on banks' profitability, pushing up lending rates on new loans to companies, including in the more dynamic export sector. The combination of measures being taken by us and at the euro area level, including non-standard measures by the ECB to restore the proper transmission of monetary policy, have started to stabilize conditions. Tentative signs of progress include the recent issuance of a bond abroad by two commercial banks- the first such issuance since mid- 2010.

13. Liquidity. Exceptional Eurosystem liquidity support is playing a pivotal role in limiting liquidity pressures and mitigating the lingering risk of excessive credit contraction. Moreover, the eligibility of additional collateral has allowed Portuguese banks to reinforce buffers and is playing a critical role in supporting their resilience against potential adverse shocks. In parallel, to facilitate the functioning of the domestic interbank market, the BdP has launched a platform for interbank unsecured lending and is developing a new one for secured transactions, which is expected to be launched by in early 2013. Banks are expected to gradually reduce their dependence on the Eurosystem liquidity over the medium term, as the deleveraging process smoothly runs its course and collateral buffers are successfully strengthened on a sustainable basis.

14. Orderly Corporate Deleveraging. As the required corporate sector deleveraging process advances, it is also crucial that the most productive and innovative segments of the economy, notably among SMEs, are not subject to undue funding strains and can effectively support the economic recovery. To this end, the Ministry of Finance, together with BdP and other stakeholders, are developing a range of measures that seek to facilitate credit to productive firms, foster the diversification of firms' financing alternatives, and reduce information asymmetry and promote more efficient financing allocation. These could include the aggregation of SMEs' debt instruments to promote access to capital markets; initiatives to help mitigate risks to lenders by upgrading and promoting sharing of information on SMEs; the rationalization and redirection to the most productive segments of the economy of existing government initiatives. We will continue to ensure that these steps do not burden or pose risks to public finances. 
15. Private Sector Restructuring. Private sector debt restructuring plays an essential role in the recovery of viable but financially vulnerable corporates and households. We continue facilitating a smooth application of the newly adopted or amended legal frameworks for corporate debt restructuring (such as the fast track in court restructuring tool, PER or SIREVE, mediated by IAPMEI). In particular, we continue raising public awareness about the new restructuring tools to promote early access by viable debtors in financial distress, while facilitating solutions to any remaining obstacles to their effective application. We will also evaluate the potential impact of the recently adopted household debt restructuring mechanisms on banks' balance sheets. These efforts are being supported by BdP's initiatives to avoid banks' evergreening and promote prompt restructuring of problem loans.

16. Bank Supervision. Efforts to strengthen the resilience of the banking system are continuing. The BdP's new onsite inspections program (OIP), launched last May and focused on assets related to the construction and commercial real estate sectors, has been completed, with the banks being expected to reflect the OIP findings in their 2012 annual accounts. This initiative is part of BdP regular supervisory activities, which are currently focused on assets classes that are more sensitive to existing market conditions. In parallel, the BdP has completed the next round of quarterly stress tests, while banks' implementation of the earlier recommendations on stress testing is progressing. Banks that have completed the capital augmentation exercise-including through successful private issuances-and despite higher impairment levels, are on track to meet the end-2012 capital targets under the program. The BdP continues to closely monitor compliance with the capital requirements, with a view to promptly take appropriate action if needed.

17. BSSF Resources. We remain committed to providing further support to the banking sector, if needed. We will continue to encourage banks to seek private solutions in the event new capital needs were to arise. Nevertheless, resources from the Bank Solvency Support Facility (BSSF) remain available to support viable banks if needed, in line with state aid rules and subject to strict conditionality, with the aim to avoid subsidizing private shareholders and preventing migration of private liabilities to the public sector balance sheet. The resources in the BSSF will solely be utilized to provide public support, if needed, to the banking system.

18. Bank Recapitalization and Resolution Frameworks. We will enhance the legal framework governing banks' access to public capital while continuing to strengthen the early intervention and resolution framework. The decree law on the banks' contributions to the resolution fund is expected to be approved by end-December, and the supervisory notice on resolution plans will be finalized by the same date. We will swiftly transpose the new EU Directive on bank resolution as soon as it enters into force. The government will, in consultation with the ECB, and the EC and the IMF, submit to Parliament by end-January 2013 (structural benchmark) amendments to the law governing banks' access to public capital so as to allow the State, under strict circumstances, to exercise control over an institution and to perform mandatory recapitalizations. Such amendments will be in line with EU State Aid rules and will strike an appropriate balance between preserving the private structure of the banking system and safeguarding the use of public resources. 
19. BPN SPVs. We are implementing the strategy for managing the distressed assets from Banco Português de Negócios (BPN). We are finalizing the terms of reference for the mandate of the professional third party that will manage the credits currently held by Parvalorem, with the aim to maximize recoveries while minimizing operational costs. The competitive bidding process to select the asset manager will be launched by end-2012, with a view to complete the tender process by mid-2013. We will also ensure timely disposal of the subsidiaries and the assets in the other two state-owned SPVs. CGD's state guaranteed claim will be gradually settled in cash, according to the schedule agreed with the EC, ECB, and IMF staff. Any net recoveries realized on the assets will also be applied towards the settlement of CGD's claim.

\section{BOOSTING EMPLOYMENT, COMPETITIVENESS, AND GROWTH}

20. ALMPs. We are delivering on commitments to support employment through Active Labor Market Policies and to improve education. The objective is to improve the employability of the young and disadvantaged categories and ease labor market mismatches. Continuous progress is being made in broadening the reach of Vida Ativa, our new targeted training initiative, and improving the role of public employment services. On the education front, we are focusing our efforts on the quality of secondary education and vocational training.

21. Labor Market Institutions. Significant steps have been taken over the past six months to make the labor market more dynamic and efficient-including the adoption of a new labor code, the reform of unemployment benefits and, more recently, the reform of the wage-setting mechanism. By mid-December 2012, we will submit to parliament a law to lower severance payments further to 12 days per year of service, bringing them in line with relevant comparators in the European Union. The law will be applied to all contracts while protecting acquired rights and maintaining the cap at 12 months of pay. Once this step is complete, the government will have reduced the restrictiveness of employment protection legislation significantly.

22. Ports and Energy. A landmark revision of the Ports Work Law, which was submitted to Parliament in September, substantially lowers wage costs and removes constraints to optimizing the use of labor. The Law is to be adopted by yearend. Follow-up measures to ensure the effective transmission of lower unit labor costs to end-users of port services include (i) encouraging price reductions under existing contract, (ii) revising incentives for port operators by adopting a new performance-based model for future concessions, and (iii) encouraging entry of new operators. Finally, responding to exporters' concern, we have reduced fees on port use (TUP-Carga) by 10 percent. Another 10-percent cut will be made effective in January. We are pursuing our efforts to cut energy costs, including by reducing excessive rents in the electricity sector.

23. Business Environment. Initiatives to tackle excessive licensing procedures, regulations and other administrative burdens-which are impeding the establishment, operation, and expansion of firms-are advancing in line with the sixth update of the Memorandum of Understanding (MoU).

24. Regulation. We are preparing a framework law for regulation that draws on the findings and recommendations of the recently completed expert report, benchmarking the responsibilities, 
resources, and independence of the main sectoral regulators against international best practices. The framework law, which will guarantee independence, as well as financial, administrative and management autonomy, and benefit from broad consultation with the regulatory bodies concerned, will be submitted to parliament by end-March 2013. While this important law is being prepared, we are amending the statutes of the electricity regulator (ERSE) to give it the appropriate powers, independence, and autonomy ahead of full market liberalization in January 2013.

25. Judicial. We have further advanced the reforms to improve the efficiency of the judicial system, including by meeting the two end-November structural benchmarks on the judicial roadmap and the new Code of Civil Procedure. Moreover, despite the challenges in addressing the backlog court cases, an additional 17,000 enforcement cases have been cleared, bringing down the total number by about 113,000 enforcement cases since November 2011 . We have adopted a decree law for a set of urgent measures designed to combat the court case backlog. The interagency task forces have set quarterly targets for reviewing enforcement cases to be closed by midFebruary 2013. To this end, we have further stepped up our efforts by expanding the task forces to small claims court cases in specific courts. Finally, and in order to relieve civil courts from mandatory intervention to determine bad debt status for VAT purposes, a comprehensive reform of the VAT rules applicable to bad debts was approved in Parliament. 


\begin{tabular}{|c|c|c|c|c|c|c|c|c|c|c|}
\hline \multicolumn{11}{|c|}{$\begin{array}{l}\text { Table1. Portugal: Quantitative Performance Criteria } \\
\text { (In billions of euros, unless otherwise specified) }\end{array}$} \\
\hline & \multirow{2}{*}{\multicolumn{2}{|c|}{ Mar-12 }} & \multicolumn{4}{|c|}{$\begin{array}{c}\text { Performance Criteria } \\
\text { (unless indicated otherwise) }\end{array}$} & \multirow{3}{*}{ Dec-12 } & \multirow{3}{*}{ Mar-13 } & \multirow{3}{*}{ Jun-13 } & \multirow{3}{*}{ 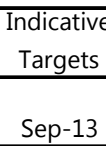 } \\
\hline & & & Jun- & -12 & Sep & -12 & & & & \\
\hline & Program & Actual & Program & Actual & Program & Actual & & & & \\
\hline $\begin{array}{l}\text { 1. Floor on the consolidated General Government cash balance } \\
\text { (cumulative) }\end{array}$ & -1.9 & -0.45 & -4.4 & -4.1 & -5.9 & -5.5 & -9.0 & -1.9 & -4.5 & 6.0 \\
\hline $\begin{array}{l}\text { 2. Ceiling on accumulation of domestic arrears by the General } \\
\text { Government (continuous indicative target) } 1 /\end{array}$ & 0 & Not met & 0 & Not met & 0 & Not met & 0 & 0 & 0 & 0 \\
\hline 3. Ceiling on the overall stock of General Government debt & 182.0 & 171.2 & 175.0 & 170.9 & 177.5 & 174.2 & 180.0 & 182.2 & 185.3 & 186.8 \\
\hline $\begin{array}{l}\text { 4. Ceiling on the accumulation of new external payments arrears } \\
\text { on external debt contracted or guaranteed by the general } \\
\text { government (continuous performance criterion) }\end{array}$ & 0 & 0 & 0 & 0 & 0 & 0 & 0 & 0 & 0 & 0 \\
\hline
\end{tabular}


Table 2. Portugal: Structural Conditionality: Sixth Review Under the EFF

Measure

Timing

Status

\section{Structural Benchmarks}

\section{A. Strengthen financial stability}

1 Make effective the amendments to the Corporate Insolvency Law to better support rescue of viable firms (after completing all necessary legislative and publication requirements)

2 Prepare a proposal for encouraging the diversification of financing alternatives to the corporate sector.

Mid-June 2012

3 Submit to Parliament amendments to the law governing banks' access to public capital (MEFP đ18).

End-July 2012

End-January 2013

\section{B. Enhance competitiveness and address bottlenecks to growth}

4 Submit to Parliament draft legislation defining the criteria for extension of collective agreements (including a majority representation threshold) and the modalities for their implementation.

5 Prepare a proposal to implement identified best international practices in order to reinforce the

End-Sept 2012

Met with delay independence of the main sectoral regulators.

6 Submit to Parliament a new Code of Civil Procedure to streamline and speed up the court procedures.

End-Sept 2012

Met

End-Nov 2012

7 Submit to Parliament the bill to implement the judicial roadmap to improve the court structure.

\section{Strengthen fiscal institutions and reduce fiscal risks}

8 Develop a PFM strategy covering the next three years, to be attached to the 2013 budget.

9 Revise and submit to Parliament the draft regional and local public finance law.

End-Dec 2012

10 Implement a full-fledged Large Taxpayer Office (LTO), to cover audit, taxpayer services, and legal

End-Dec 2012 functions concerning all large taxpayers, including the adoption of account managers. 


\title{
ATTACHMENT II. PORTUGAL: TECHNICAL MEMORANDUM OF UNDERSTANDING
}

\author{
December 19, 2012
}

1. This Technical Memorandum of Understanding (TMU) sets out the understandings regarding the definitions of the indicators subject to quantitative targets (performance criteria and indicative targets), specified in the tables annexed to the Memorandum of Economic and Financial Policies. It also describes the methods to be used in assessing the Program performance and the information requirements to ensure adequate monitoring of the targets. We will consult with the $E C$, the ECB, and the IMF before modifying measures contained in this letter or adopting new measures that would deviate from the goals of the Program, and provide the EC, the ECB, and the IMF with the necessary information for Program monitoring.

2. For Program purposes, all foreign currency-related assets, liabilities, and flows will be evaluated at "Program exchange rates" as defined below, with the exception of the items affecting government fiscal balances, which will be measured at spot exchange rate (i.e., the rate for immediate delivery) prevailing on the date of the transaction. The Program exchange rates are those that prevailed on May 5, 2011. In particular, the exchange rates for the purposes of the Program are set $€ 1=1.483$ U.S. dollar, $€ 1=116.8390$ Japanese yen, $€ 1.09512=1$ SDR.

3. For reporting purposes, the MoF and BdP will employ the reporting standards and templates considered to be appropriate given the transmission of data covered by this TMU, unless otherwise stated or agreed with the EC, the ECB and the IMF.

\section{General Government}

4. Definition. For the purposes of the Program, the General Government, as defined in the Budget Framework Law, Law No. 91/2001 of August 20, amended by Law 22/2011 of May 20, includes:

- 4.1. The Central Government. This includes:

- 4.1.1. The entities covered under the State Budget, which covers the budgets of the Central Administration, including the agencies and services that are not administratively and financially autonomous, agencies and services that are administratively and financially autonomous (Serviços e Fundos Autónomos - SFA).

- 4.1.2. Other entities, including Incorporated State-owned enterprises (ISOE), or extrabudgetary funds (EBF) not part of the State Budget, but which are, under the European System of Accounts (ESA95) and ESA95 Manual on Government Deficit and Debt rules, classified by the National Statistical Institute (INE) as part of the Central Government. 
- 4.2. Regional and Local Governments, that include:

- 4.2.1. Regional Governments of Madeira and Azores and Local Governments (Administrações Regionais and Locais);

- 4.2.2. Regional and local government-owned enterprises or companies, foundations, cooperatives and other agencies and institutions, which are, under the ESA95 and ESA95 Manual on Government Deficit and Debt rules, classified by the INE as Local Government.

- 4.3. Social Security Funds comprising all funds that are established in the general social security system.

- This definition of General Government also includes any new funds, or other special budgetary and extra budgetary programs or entities that may be created during the Program period to carry out operations of a fiscal nature and which are, under the ESA95 and ESA95 Manual on Government Deficit and Debt rules, classified by the INE in the correspondent subsector. The MoF will inform the EC, ECB, and IMF of the creation of any such new funds, programs, entities or operations at the time of its creation or statistical reclassification or, in the case of Regional and Local Governments, at the time the Government acknowledges its creation.

- The General Government, as measured for purposes of Program monitoring in 2012, shall not include entities nor operations (including pension funds) that are re-classified into the General Government during 2012, but shall include those reclassified in $2011{ }^{1}{ }^{1}$

\section{Supporting Material}

- 5.1. Data on cash balances of the State Budget will be provided to the EC, the ECB and the IMF by the MoF within three weeks after the end of the month. Data will include detailed information on revenue and expenditure items, in line with monthly reports that are published by the MoF.

- 5.2. Data on the cash balances of the other parts of General Government as defined in paragraph $4^{2}$ will be provided to the EC, the ECB and the IMF by the MoF within seven weeks

\footnotetext{
${ }^{1}$ An operation refers to part of a legal entity that is involved in the production or delivery of goods and services-including government services provided on a nonmarket basis. As such, it does not include transactions relating to the assets or liabilities of an entity. For example, should an entity handle a number of PPPs, reclassifying only one PPP would be considered as reclassifying an operation. In contrast, taking over part of an entity's debt by the government would not qualify for the exclusion. On this issue, see also paragraph 13.

${ }^{2}$ In 2011, data exclude regional and local government-owned enterprises or companies, foundations, cooperatives and other agencies and institutions, which are, under the ESA95 and ESA95 Manual on Government Deficit and Debt rules, classified by the INE as Local Government, i.e., entities referred in paragraph 4.2.2.
} 
after the end of the month. Data will include detailed information on revenue and expenditure items. Data will also include detailed information on PPP-related revenues and expenditures for those PPP reclassified within the General Government sector according to ESA 95, and called guarantees.

- 5.3. Data on domestic and external debt redemptions (securities), new domestic and external debt issuance (securities), change in the domestic and foreign currency assets and liabilities of the Central Government at the BdP and other financial institutions will be provided to the $E C$, the ECB, and the IMF by the BdP within 40 days after the closing of each month.

- 5.4. BdP will provide to the $\mathrm{EC}$, the $\mathrm{ECB}$, and the IMF detailed monthly data on the financing of the General Government, as defined in ESA95, within seven weeks after the closing of each month.

- 5.5. Data on the revenues, operating expenses, capital expenditure, remuneration of personnel, EBITDA, and number of staff will be provided for state-owned enterprises (SOEs) on a quarterly basis, within 7 weeks after the end of each quarter. Aggregate data for the SOEs within the perimeter will be provided, with company-specific information for REFER, Estradas de Portugal, Metro de Lisboa, and Metro de Porto. Furthermore data for Comboios de Portugal and Parpública (outside the perimeter) will also be provided.

\section{QUANTITATIVE PERFORMANCE CRITERIA, INDICATIVE CEILINGS, AND CONTINUOUS PERFORMANCE CRITERIA: DEFINITIONS AND REPORTING STANDARDS}

\section{A. Floor on the Consolidated General Government Cash Balance (Performance Criterion)}

6. Definition. The consolidated General Government cash balance (CGGCB) is defined as the sum of the cash balances of the entities covered by the State Budget, the ISOE, the Regional and Local Governments, and the Social Security Funds, and other entities and EBFs, as defined in paragraph 4. Privatization receipts will be excluded from cash receipts. In 2012 and beyond, revenues from the reclassification of pension funds into the general government will not be accounted for as cash revenues for the purpose of the calculation of the consolidated general government cash balance. In 2012-13, the cash proceeds from the sale of the ANA airport concession will be accounted for as cash expenditure-reducing transactions. The net acquisition of financial assets for policy purposes, including loans and equity participation will be recorded as cash expenditures, except for transactions related to the banking sector support and restructuring strategy under the Program. Called guarantees (excluding those related to the banking sector support and restructuring strategy), where entities of the General Government make cash payments on behalf of entities that are not part of the General Government, will be recorded as cash expenditures. 
6.1. The Cash Balance of the State Budget. The cash balance of the State Budget will be measured from above the line, based on budget revenues (recurrent revenue plus nonrecurrent revenue, including EU revenues, minus tax refunds) minus budget expenditures of the State Budget as published monthly on the official website of the DGO of the MoF, and in line with the corresponding line items established in the State Budget. Budget expenditures will exclude amortization payments but include salaries and other payments to staff and pensions; grants to Social Security Funds, medical care and social protection; operational and other expenditure, interest payments; cash payments for military equipment procurement; and EU expenses.

\subsection{The Cash Balance of the Regional and Local Governments, Social Security Funds, ISOE}

and Other Entities or EBFs. The cash balance of each of these parts of the General Government will be measured from above the line, based on revenues minus expenditures as it will be provided by the DGO of the MoF in the monthly General Government budget execution report (see Para 5), and in line with the corresponding line items established in their respective budgets. All entities including ISOE that prepare accrual-based financial statements will submit monthly cash flow statement in accordance with form and content specified by the MoF. The reporting by Local Government will be phased as set out in paragraph 8 below.

6.3. Adjustor. The 2012 and 2013 quarterly floors on the consolidated general government cash balance will be adjusted for the cumulative amount of arrears settled in the context of the arrears clearance strategy: (i) health sector arrears (up to $€ 1.95$ billion), and (ii) local government arrears settled through the $€ 1$ billion credit facility created in May 2012. The targets will also be adjusted for the clearance of other arrears provided an agreement to this effect was reached with IMF staff.

\section{Other Provisions}

7. For the purpose of the program, the expenditure of the central government that is monitored excludes payments related to bank support, when carried out under the program's banking sector and restructuring strategy. However, any financial operation by central government to support banks, including the issuance of guarantees or provision of liquidity, will be immediately reported to the $E C, E C B$, and IMF.

8. Quarterly consolidated accounts for the General Government on a cash basis will be reported for internal, EC, ECB, and IMF monitoring 7 weeks after the reference period, starting with the first quarter of 2012. The reports will be published externally starting with December 2011 data. SOEs will be consolidated with the general government accounts starting with the first quarter 2012 . The larger municipalities (defined as those with a population of 100,000 voters or more) are required to provide monthly reports under current arrangements, and their cash balance will be included in the calculation of the monthly cash General Government balance. The cash balance of the smaller municipalities, i.e. those with a population of under 100,000 voters, will be excluded until any necessary legal changes requiring them to provide monthly reports have been put in place. In this transitory period, the MoF will provide a monthly estimate of the cash balance of these smaller municipalities excluded from the General Government reports to the EC, the ECB, and the IMF. 


\section{Supporting Material}

9.1. Data on cash balances of the State Government, ISOEs, Regional and Local Government and Social Security Funds will be provided to the EC, the ECB and the IMF by the MoF within seven weeks after the end of each month. The information provided will include general government net acquisitions of financial assets for policy purposes, including loans and equity participations, as well as called guarantees where entities that are part of the General Government make cash payments on behalf of entities that are not part of the General Government.

9.2. The MoF will submit quarterly data on General Government accounts determined by the INE in accordance with ESA 95 rules, showing also the main items of the transition from cash balances to the General Government balances in national accounts. The reconciliation will be accompanied by necessary explanatory materials for any indication of potential deviation of the annual general government cash target from the annual general government accrual target determined in accordance with ESA 95 rules.

\section{B. Non-Accumulation of New Domestic Arrears by the General}

\section{Government (Continuous Indicative Target)}

10. Definitions. Commitment, liabilities, payables/creditors, and arrears can arise in respect of all types of expenditure. These include employment costs, utilities, transfer payments, interest, goods and services and capital expenditure. Commitments are explicit or implicit agreements to make payment(s) to another party in exchange for that party supplying goods and services or fulfilling other conditions. Commitments can be for specific goods and services and arise when a formal action is taken by a government agency, e.g., issuance of a purchase order or signing a contract. Commitment can also be of a continuing nature that require a series of payments over an indeterminate period of time and may or may not involve a contract, e.g. salaries, utilities, and entitlement payments. Liabilities are present obligations of the entity arising from past events, the settlement of which is expected to result in an outflow from the entity of resources (usually cash) embodying economic benefits or service potential. In relation to commitment, the liability arises when a third party satisfies the terms of the contract or similar arrangement. Payables/creditors are a subset of liabilities. For the purposes of the program payables/creditors exclude provisions, accrued liabilities. Arrears are a subset of payables/creditors. For the purposes of the Program domestic arrears are defined as payables/creditors (including foreigner commercial creditors), that have remained unpaid for 90 days or more beyond any specified due date (regardless of any contractual grace period). In case no due date is specified, arrears are defined as payables/creditors that have remained unpaid for 90 days or more after the date of the invoice or contract. Data on arrears will be provided within seven weeks after the end of each month. The continuous indicative target of non-accumulation of new domestic arrears requires that the total arrears at the end of any month are not greater than the corresponding total at the end of the previous month-based on the same perimeter with respect to the entities covered. This also includes arrears that are being accumulated by the SOEs not included in the General Government. 
11. Supporting Material. The stock of arrears will be measured through a survey. Reports on the stock of arrears of the General Government are being published monthly. The MoF will provide consistent data on monthly expenditure arrears of the General Government, as defined above. Data will be provided within seven weeks after the end of each month and will include total arrears classified by the different constituent sectors of the General Government sub-sector as defined in paragraph 4, as well as the monthly amounts of (i) health sector arrears settled with the banks' pension funds transfers' resources, and (ii) local government arrears settled through the $€ 1$ billion credit facility created in May 2012.

12. Adjustor. The monthly change in the stock of arrears will be adjusted for any stock adjustment related to the arrears clearance strategy: (i) health sector arrears, as well as local government arrears settled through the $€ 1$ billion credit facility created in May 2012. This will allow monitoring the underlying flow of new arrears.

\section{Ceiling on the Overall Stock of General Government Debt (Performance Criterion)}

13. Definition. The overall stock of General Government debt will refer to the definition established by Council Regulation (EC) No 479/2009 of 25 May 2009 on the application of the Protocol on the Excessive Deficit Procedure annexed to the Treaty establishing the European Community. For the purposes of the Program, the stock of General Government debt will exclude: (i) debt contracted for bank restructuring, when carried out under the Program's banking sector support and restructuring strategy; (ii) IGCP deposits; and (iii) (from end-September 2011) the 'prepaid margin' on all EFSF loans.

14. Adjusters. For 2012, the ceiling of the overall stock of General Government debt will be adjusted upward (downward) by the amount of any upward (downward) revision to the stock at end-December 2011 general government debt of EUR183.33 billion. From 2013 onwards, the ceiling of the overall stock of General Government debt will be adjusted upward (downward) by the amount of any upward (downward) reclassification of entities or operations that affects the stock at end-December of the previous year.

15. Supporting Material. Quarterly data on the total stock of General Government debt as defined in paragraph 12 will be provided to the EC, ECB and IMF by the BdP no later than 90 days after the end of each quarter, as reported to the ECB and the Eurostat. Monthly estimates will be provided to the EC, ECB and IMF by BdP no later than seven weeks after the end of each month.

\section{Non-Accumulation of New External Debt Payments Arrears by the General Government (Continuous Performance Criterion)}

16. Definition. For the purposes of the Program, the definition of debt is the same as in paragraph 12. An external debt payment arrear will be defined as a payment on debt to nonresidents, contracted or guaranteed by the general government, which has not been made 
within seven days after falling due (taking into account any applicable contractual grace period). The performance criterion will apply on a continuous basis throughout the Program period.

17. Supporting Material. Any external debt payment arrears of the General Government will be immediately reported by the MoF.

\section{E. Bank Solvency Support Facility}

18. The dedicated Bank Solvency Support Facility (BSSF) account will be maintained at the Bank of Portugal. As per previous review, resources for the BSSF will be agreed at each review and deposited in the dedicated account.

\section{F. Overall Monitoring and Reporting Requirements}

19. Performance under the Program will be monitored from data supplied to the EC, the ECB, and the IMF by the MoF and BdP. The authorities will transmit to the EC, ECB, and IMF any data revisions in a timely manner. 


\title{
APPENDIX II. PORTUGAL: LETTER OF INTENT TO THE EUROPEAN COMMISSION AND THE EUROPEAN \\ CENTRAL BANK
}

Lisbon, 20 December 2012

\author{
Mr Jean-Claude Juncker \\ President \\ Eurogroup \\ Mr Vassos Shiarly \\ Minister of Finance \\ Cyprus \\ Mr Olli Rehn \\ Vice President \\ European Commission \\ Mr Mario Draghi \\ President \\ European Central Bank
}

Dear Sirs,

The attached Memorandum of Understanding (MoU) describes the progress made in recent months towards the objectives laid out in our Programme. It also updates previous MoUs and highlights the policy steps to be taken in the months ahead.

We remain strongly committed to the programme's policies and objectives and expect the agreed 5 percent deficit target for 2012 to be achieved. The 2013 budget was approved by the Parliament, including a range of tax and spending measures that should ensure that the general government deficit of $4 \frac{1}{2}$ percent of GDP will be achieved next year. To advance with the additional fiscal adjustment that is required in coming years, we have initiated a comprehensive public expenditure review exercise to be completed early in 2013.

Consistent with our commitment to implement a multi-year strategic plan to strengthen fiscal discipline, we are intensifying our efforts to prevent the increase in the stock of existing domestic arrears. We are reforming the SOE sector, which has been brought to overall operational balance, as per our commitment, after many years of chronic deficits. We will continue this restructuring effort and actively manage their high legacy debt burden. Moreover, the privatisation is proceeding as scheduled and we are advancing our strategy to put the PPPs on a sustainable financial path.

Our policy efforts to preserve financial stability will continue, as banks are on track to meet the 2012 capital requirements, following the recent capital exercise. Banco de Portugal (BdP) continues on its 
supervisory effort to ensure adequate impairment levels, as evidenced by the successful completion of the latest on-site inspection. In addition, the recapitalisation and resolution framework will be further strengthened. The Portuguese authorities are preparing a proposal for the setting-up of a mechanism to securitise high-quality mortgage credit with a supranational guarantee. Moreover, we are exploring a new proposal to rationalise and redirect to the most productive segments of the economy existing government initiatives, including the setting up of a revolving mechanism to leverage EU structural funds. Finally, we will also continue consultations with the European Commission on the rate of remuneration of financial instruments used for recapitalisation purposes. In pursuing this route, we are motivated by concerns on local funding and lending conditions.

We have made important advances in many dimensions of our ambitious structural reform agenda, and will continue to press ahead with measures to improve the business environment and help spur investment. Measures to actively promote employment and improve education are being expanded. With the completion of the reduction of severance payments, to be soon submitted to the Parliament, we will have reduced the rigidity of labour contracts substantially. A landmark revision of the Ports Work Law in discussion in the Parliament will increase efficiencies and help reduce costs for exporters. Going forward, we will continue to pursue a streamlined and more effective licensing and regulatory framework along with a reform in corporate taxation, as part of our strategy to attract more investment and boost competitiveness.

On the basis of the strength of the policies defined in this letter, and in light of our performance under the Programme, we request the completion of the sixth review under the Economic Adjustment Programme and the release of the seventh instalment under the Programme in the amount of EUR 1600 million.

We remain confident that the policies described in the current and previous MoUs are adequate to achieve the objectives under the Programme. We stand ready to take additional measures should they be needed to meet the objectives of the Economic Adjustment Programme and will consult with the European Commission, the ECB and the IMF in advance of any necessary revisions to the policies contained in this letter and attached Memorandum.

This letter is copied to Ms Christine Lagarde.

Sincerely yours,

$\frac{\text { /s/ }}{\text { Vítor Gaspar }}$ Minister of State and Finance $\quad$ Governor of the Banco de Portugal

Attachments: Memorandum of Understanding (MoU); Memorandum of Economic and Financial Policies (MEFP); Technical Memorandum of Understanding (TMU) 


\title{
ATTACHEMENT I. MEMORANDUM OF UNDERSTANDING ON SPECIFIC ECONOMIC POLICY CONDITIONALITY
}

\author{
Sixth Update - 20 December 2012
}

With regard to Council Regulation (EU) n 407/2010 of 11 May 2010 establishing a European Financial Stabilisation Mechanism (EFSM), and in particular Article 3(5) thereof, the sixth update of the Memorandum of Understanding on specific economic policy conditionality (MoU) details the general economic policy conditions as embedded in Council Implementing Decision 2011/344/EU of 17 May 2011 on granting Union financial assistance to Portugal. ${ }^{1}$

The first disbursement of financial assistance from the EFSM took place following the entry into force of the MoU and of the Loan Agreement.

The Council Implementing Decision specifies that the release of further instalments is conditional on a positive conclusion of the reviews of conditionality that will take place throughout the three-year duration of the programme. These reviews will assess progress made with respect to the policy criteria in the Council Implementing Decision and specified in the Memorandum of Economic and Financial Policies (MEFP) and in this updated MoU, as well as Council Recommendations in the context of the Excessive Deficit Procedure.

The sixth quarterly review was carried out in November 2012. It assessed compliance with the conditions to be met by end-October and the need and scope for additional policy steps. This sixth update of the MoU reflects the findings of the sixth review. The following reviews taking place in any given quarter will assess compliance with the conditions to be met by the end of the previous quarter or, where applicable, up to date of the mission.

If targets are missed or expected to be missed, additional action will be taken. The authorities commit to consult with the European Commission (EC), the European Central Bank (ECB) and the International Monetary Fund (IMF) on the adoption of policies falling within the scope of this updated Memorandum, allowing sufficient time for review. Staff of the EC, the ECB and the IMF will, in cooperation with the Portuguese authorities, monitor and assess progress in the implementation of the programme and track the economic and financial situation. Staff will also monitor whether the implementation and effects of measures taken by the Portuguese authorities fall short of the commitments of previous versions of the MoU; such commitments might be re-inserted. To this effect the authorities commit to provide all required information as soon as available. In areas where there are risks of significant delays in the implementation of policies under this programme the authorities in cooperation with the EC, the ECB and the IMF consider making use of technical assistance.

Prior to the release of the instalments, the authorities shall provide a compliance report on the fulfilment of the conditionality.

\footnotetext{
${ }^{1}$ On 8 April 2011, Eurogroup and ECOFIN Ministers issued a statement clarifying that financial support of the EU (European Financial Stabilisation Mechanism, EFSM) and the euro-area (European Financial Stability Facility, EFSF) would be provided on the basis of a policy programme supported by strict conditionality and negotiated with the Portuguese authorities, duly involving the main political parties, by the Commission in liaison with the $E C B$, and the IMF. Further to the EU support from the EFSM, loans from the EFSF will contribute to the financial assistance. The Loan Facility Agreement on the EFSF financing contribution specifies that the disbursements thereunder are subject to the compliance with the conditions of this Memorandum.
} 


\section{Fiscal policy}

\section{Objectives}

Reduce the Government deficit to 5\% of GDP in 2012, 41/2\% of GDP in 2013 and $2 \frac{1}{2} \%$ of GDP in 2014 by means of high-quality permanent measures and minimising the impact of consolidation on vulnerable groups. The fiscal consolidation over the medium-term up to a balanced budgetary position will be maintained, notably by containing expenditure growth. Growth-friendly tax policy will be pursued through, among others, a comprehensive reform of corporate taxation to promote investment and competitiveness.

\section{Fiscal policy in 2012}

1.1. The government will achieve a general government deficit of no more than EUR 8.3 billion (5 percent of GDP) in 2012 on ESA95 basis. $^{2}$ [Q4-2012]

1.2. Throughout the year, the government will rigorously implement the Budget Law for 2012, as amended by the Supplementary Budget. In addition, the government has adopted measures to confine the deficit to 5\% of GDP in 2012 by freezing budget appropriations for investment projects not yet initiated, generating savings in intermediate consumption and raising stamp duties on high value properties and withholding tax rates on capital income. Within the year, progress will be assessed against the (cumulative) quarterly ceilings for the consolidated general government cash balance in the MEFP, as defined in the TMU, without prejudice to full-year ESA-95 deficit targets.

\section{[Q4-2012]}

1.3. The authorities will frontload to 2012 some of the 2013 budget measures affecting social benefits to obtain savings worth at least $0.1 \%$ of GDP. These include, inter alia, cuts in reimbursements of funeral expenses, transfers in case of death, and dependency supplements.

\section{Fiscal policy in 2013}

1.4. The government will achieve a general government deficit target of no more than EUR 7.5 billion (41/2 percent of GDP). [Q4-2013]

1.5. Throughout the year, the government will rigorously implement the Budget Law for 2013. Progress will be assessed against the (cumulative) quarterly ceilings for the consolidated general government cash balance in the Memorandum of Economic and Financial Policies (MEFP), as defined in the Technical Memorandum of Understanding (TMU), without prejudice to full-year ESA95 deficit targets. [Q1, Q2, Q3 and Q4-2013]

\footnotetext{
${ }^{2}$ In 2012, operations related to the banking sector support and restructuring strategy under the programme will not be considered for the assessment of compliance with the programme target for the general government deficit.
} 
1.6. Permanent consolidation measures of slightly above 3\% of GDP have been proposed with the 2013 Budget Law to reach the $4 \frac{1}{2} \%$ of GDP deficit target in 2013 . The measures listed below will be detailed and carried out with the 2013 Budget Law [Q4-2012], unless otherwise specified:

\section{Expenditure}

1.7. Reduce the public sector wage bill in gross terms by at least EUR 700 million by, among others:

i. decreasing the number of government employees by; (i) limiting staff admissions in order to achieve annual decreases at least of 2 percent (full-time equivalent) in 20132014 in the permanent staff of central, regional and local governments; (ii) a 50 percent reduction of fixed-term contracts; (iii) optimizing the allocation of resources as specified below under the section on the Public Administration/Human Resources, mainly as regards the special mobility scheme.

ii. other measures such as reducing over-time payments, enforcing private sector sickness benefit regime in the public sector and reducing compensation during extraordinary leave.

1.8. Savings in the national health service (at least EUR 180 million) by further rationalisation of available resources and pharmaceuticals' policy. Further savings, in particular in hospitals SOEs, are specified below under the section on the health-care system.

1.9. Reduce pension expenditure in a progressive manner by at least EUR 400 million.

1.10. Streamline social benefits expenditure by strengthening control and better targeting social support (at least EUR 450 million).

1.11. Reduce intermediate consumption (at least EUR 375 million) through efficiency gains in the general government administration and the renegotiation of PPP contracts.

1.12. Reduction in transfers, among others to foundations and SOEs (at least EUR 120 million)

1.13. Reduce capital expenditure, particularly in SOEs (at least EUR 250 million)

\section{Revenue}

1.14. Amend the personal income tax (yielding at least EUR 3 billion) by:

i. reducing the number of tax brackets and increasing the average tax rate in line with European standards, while preserving progressivity of the tax and delinking social benefits from the tax structure;

ii. introducing a surcharge of $3.5 \%$ on the part of taxable income above minimum wage, and a solidarity surcharge of $2.5 \%$ on the income of the top tax bracket and of $5 \%$ on the income exceeding EUR 250 000;

iii. increasing the tax rate on capital income;

iv. equalizing the tax rates on capital income between residents and non-residents;

v. lowering the basic personal deduction;

vi. reducing deductibility of mortgage interest payments; 
vii. curbing some fiscal benefits.

1.15. Increase corporate tax revenues by at least EUR 200 million by:

i. limiting the deductibility of interest costs;

ii. curbing tax benefits;

iii. reducing the threshold for application of the highest tax rate on profits;

iv. amending the method for special prepayment applicable to companies under the regime for taxation of groups of companies.

1.16. Increase other indirect taxes (by at least EUR 685 million), such as:

i. excises by raising taxes on tobacco, alcohol and natural gas;

ii. property taxes by broadening the property taxation base after revaluation, and stamp tax surcharges for high-value properties;

iii. financial transaction tax.

1.17. Maintain the standstill rule for tax expenditures at central, regional or local level, except for the possibility of introducing additional tax benefits aimed at boosting investment.

1.18. Increase social contributions (at least EUR 270 million), by including supplementary payments to public employees and unemployment benefits in the social contributions' calculations.

1.19. Strengthen efforts to fight tax evasion, fraud and informality for various types of taxes inter alia by increasing means available for audits, increasing penalties for the most serious tax crimes and introducing a new VAT invoicing system.

1.20. With a view to addressing risks of budgetary execution in 2013 the authorities will prepare contingency measures worth at least $1 / 2$ percent of GDP. Most of these will come from a frontloading of the measures of the comprehensive expenditure review and will be further specified at the seventh review. A significant share of these measures will consist in additional reductions in the wage bill and increased efficiency in the functioning of public administration, namely as regards working time organisation. Moreover, budgetary appropriations will be adjusted in case budgetary execution risks materialise.

\section{Fiscal policy in 2014}

1.21. The government will achieve a general government deficit of no more than EUR 4.3 billion (21/2 percent of GDP) in 2014. [Q4-2014].

1.22. A comprehensive expenditure review has been initiated with the objective to enhance the efficiency and equity of public policy, while generating spending savings of about EUR 4 billion in 2014. In the framework of this review, the identification, quantification and timetable of implementation of measures will be fully specified by mid-February 2013 in time for the seventh review. The exercise will aim at reducing redundancies across the public sector functions and entities, and reallocating resources toward growth-friendly spending areas. [Q1-2013] The fiscal consolidation plans for 2014-15 will be fully detailed in the 2013 Stability Programme. [Q2-2013] 
1.23. Within the year, progress will be assessed against the (cumulative) quarterly ceilings for the consolidated general government cash balance in the Memorandum of Economic and Financial Policies (MEFP), as defined in the Technical Memorandum of Understanding (TMU), without prejudice to full-year ESA-95 deficit targets. [Q1 and Q2-2014]

\section{Financial sector regulation and supervision}

Preserve financial sector stability; maintain liquidity and support a balanced and orderly deleveraging in the banking sector; ensure adequate financing and working capital for the productive sectors; strengthen banking regulation and supervision; develop and implement solutions that provide financing alternatives to traditional bank credit for the corporate sector; optimise the process for recovering the assets transferred from BPN to the three state-owned SPVs; streamline state-owned Caixa Geral de Depósitos; complete the bank resolution framework and reinforce the Deposit Guarantee Fund and the Guarantee Fund for Mutual Agricultural Credit Institutions; complete the corporate and household insolvency frameworks and smoothen their implementation.

Maintaining liquidity in the banking sector

2.1. Encourage banks to strengthen their collateral buffers on a sustainable basis and to take full advantage of the broadening of the range of eligible collateral for the purpose of Eurosystem refinancing. The Banco de Portugal (BdP), in close cooperation with the $E C B$, will continue to monitor closely the liquidity situation of the banking system and stands ready to take the appropriate measures to maintain sufficient system liquidity. [Ongoing] A new platform for interbank unsecured lending has been put in place and the BdP is expected to extend it to secured interbank lending by the beginning of next year.

\section{Deleveraging in the banking sector}

2.2. The banking system should in the medium run eliminate its funding imbalances. Monitor the banks' implementation of the funding plans aiming at an indicative loan-to-deposit ratio of about $120 \%$ in 2014 . It is important that the pace and composition of deleveraging should not jeopardise the provision of appropriate credit to finance productive investment and working capital in the private sectors of the economy, not least SMEs. Fiscal adjustment and an attendant reduction in the public sector's financing are crucial for reconciling potentially conflicting objectives. In addition, the BdP will implement the measures taken to discourage evergreening of doubtful loans with a view to facilitating an effective adjustment of bank balance sheets respecting EU state aid rules. In this context, banks are identifying and reporting recently restructured loans due to debtors' financial difficulties and the first report by the BdP is expected by end-November 2012. These steps will be taken without burdening or posing risks to public resources. Banks' funding and capital plans and broader credit developments will continue to be monitored closely. There is room for the necessary deleveraging to take place in an orderly manner and it is crucial that the pace and composition of the deleveraging remain consistent with the macroeconomic framework of the programme. [Ongoing] 


\section{Capital buffers}

2.3. Ensure that the programme target of a Core Tier 1 ratio of $10 \%$ by end-2012 target is reached including through the monitoring of the restructuring plans banks having received public capital support were requested to draw up, aiming at enhancing the banks' resilience.

2.4. BdP is closely monitoring compliance with the capital requirements for all banks, with a view to promptly take appropriate action if needed. [Ongoing]

2.5. Remain committed to provide further support to the banking system, if needed. Resources from the Bank Solvency Support Facility (BSSF) are available in line with state aid rules to further support viable banks, subject to strict conditionality. Avoid subsidizing private shareholders and prevent further migration of private liabilities to the public sector balance sheet. In the event new capital needs were to arise, banks are encouraged to seek private solutions. [Ongoing]

Caixa Geral de Depósitos (CGD)

2.6. Continue to streamline the state-owned CGD group.

Banking regulation and supervision

2.7. The BdP will continue to strengthen its supervisory organisation, optimise its supervisory processes and develop and implement new supervisory methodologies and tools. The field work of a new onsite inspections program (OIP) launched in May 2012 by the BdP has been completed in the major banking groups. The OIP findings are expected to be reflected in 2012 annual accounts of these institutions. This initiative is part of BdP regular supervisory activities, which are currently focused on assets classes that are more sensitive to existing market conditions.

2.8. In addition, the BdP is stepping up the monitoring of banks, including via ad hoc audits. [Ongoing]

2.9. BdP will remain committed to close coordination with home and host country supervisors, both within and outside the EU. [Ongoing]

Monitoring of bank solvency

2.10. The BdP will continue to monitor on a quarterly basis the banks' potential capital needs with a forward looking approach under stress conditions. In this context, banks will reflect the OIP findings in the implementation of the SIP recommendations on asset quality and stress testing methodologies by end-December 2012, with the update of the treatment of collective impairments expected to be finalized at the latest by end-June 2013.

Banco Português de Negócios

2.11. Gradually settle CGD's state guaranteed claim on the SPVs in cash, according to the schedule agreed with the EC, ECB and IMF. Any recoveries on the assets held by the three stateowned SPVs will also be used to promptly repay CGD. [Ongoing]

2.12. Outsource the management of the credits currently held by Parvalorem to a professional third party, with a mandate to gradually recover the assets over time. Select the party managing the credits through a competitive bidding process, to be launched by end-2012, at the latest, and with 
a view to complete it by mid-2013. Include proper incentives to maximise the recoveries and minimise operational costs into the mandate. Ensure timely disposal of the subsidiaries and the assets in the other two state-owned SPVs.

Bank resolution framework

2.13. The early intervention, resolution and deposit guarantee framework has been strengthened. The authorities are asked to conclude the implementing measures, In particular, the following actions will be taken: (a) the approval of a decree-law on the banks' contributions to the resolution fund by end-2012 and (b) the approval of a supervisory notice on the resolution plans by the same date, taking into account, to the extent possible in view of the deadline, the EBA recommendations and templates. The implementation of the recovery and resolution plans of the banks will give priority to those of systemic importance.

2.14. The legislator will closely follow the process of adoption of the EU Directive on resolution and revise the national resolution framework as soon as the Directive enters into force. [Ongoing]

Bank recapitalisation framework

2.15. The Government will, in consultation with the ECB, and the EC and the IMF staff, submit to Parliament by [end-January 2013] ${ }^{3}$ amendments to the legal framework governing access to public capital to allow the State, under strict circumstances and in accordance with state aid rules, to exercise control over an institution and to perform mandatory recapitalisations.

Corporate and household debt restructuring framework

2.16. Implement the recently established framework for financial institutions to engage in outof-court debt restructuring for households, smoothen the application of the framework for restructuring of corporate debt and implement an action plan to raise public awareness of the restructuring tools. [Ongoing]

Monitoring of corporate and household indebtedness

2.17. Continue the monitoring of the high indebtedness of the corporate and household sectors through the quarterly reports. [Ongoing]

Encouraging the diversification of financing alternatives to the corporate sector

2.18. The Ministry of Finance, the BdP, and other stakeholders, have put forward a set of preliminary proposals to encourage the diversification of financing alternatives to the corporate sector ${ }^{4}$.

i. Develop and evaluate the different options put forward with a view to set priorities [Ongoing] and submit a detailed assessment on the proposal concerning the grouped issuance of corporate debt, in particular of SMEs, to obtain capital markets financing [endJanuary].

\footnotetext{
${ }^{3}$ Structural benchmark in the Memorandum of Economic and Financial Policies.

${ }^{4}$ Structural benchmark in the Memorandum of Economic and Financial Policies.
} 
ii. Consider in this exercise also the measures to facilitate access to finance for SMEs [Ongoing] and assess the effectiveness of EU-compatible government-sponsored export credit insurance schemes with a view to take appropriate measures to promote exports [Q12013].

\section{Fiscal-structural measures}

\section{Objectives}

Improve the efficiency of the public administration by eliminating redundancies, simplifying procedures and reorganising services; regulate the creation and functioning of all public entities including SOEs, PPPs, foundations, associations; re-focus their activities to core public policy objectives and enhance their cost efficiency and fiscal sustainability; streamline the budgetary process, including by adopting new financing laws at regional and local level; strengthen risk management, accountability, reporting and monitoring of all parts of the general government. Government action will build on the recommendations provided by the IMF/EU technical assistance missions.

\section{Public Financial Management framework}

Reporting and Monitoring

3.1. Publish a comprehensive report on fiscal risks each year as part of the budget. The report will outline general fiscal risks and specific contingent liabilities to which the general government may be exposed, including those arising from Public-Private Partnerships (PPPs), SOEs and explicit guarantees to the banks. Technical assistance will be provided if necessary.

3.2. Publish a tax expenditure report each year as part of the budget. The report will define a clear methodology to estimate and to evaluate tax expenditures, in line with international best practices. The report will cover central, regional and local administrations.

3.3. Reduce the number of Serviços e Fundos Autónomos (SFA) in view of reducing budget fragmentation and improving efficiency in the general government. In particular, this reform will be deepened by reviewing the classification of own revenues to enlarge central government revenues. [Q3-2013]

\section{Arrears}

3.4. The stock of domestic arrears will be significantly reduced by the end of the programme period. A significant part of the existing arrears was reduced as laid down in the strategy for the settlement of arrears. The Inspeção Geral de Finanças (IGF) will carry out inspections throughout the process to verify compliance of the commitment control system through a risk-based approach. [Ongoing]

3.5. IGF will reinforce the verification of local governments' arrears claims and commitment control systems. Disbursements under the "Programa de Apoio à Economia Local" (PAEL) will only take place where IGF has certified the full functioning of the commitment control system. Transparency of the use of the credit line will be ensured through the monthly publication of the 
amounts lent, disbursed, and used to settle arrears and other liabilities by municipality in the framework of the PAEL. [Ongoing]

\section{Budgetary framework}

3.6. Publish a fiscal strategy document for the general government annually in April. The document will be in compliance with the requirements of the Stability and Growth Pact and will specify 4-year medium-term economic and fiscal forecasts and 4-year costs of new policy decisions. Budgets will include a reconciliation of revisions to the 4 year fiscal forecasts attributable to policy decisions and parameter revisions e.g. policy decisions, changes in the macroeconomic environment.

3.7. Review the Budget Framework Law to take account of the reinforced EU fiscal framework and the Treaty on Stability, Coordination and Governance in the Economic and Monetary Union (fiscal compact). The revised law will also accommodate the developments in the regional and local financing laws. [Q4-2012] Conduct a review of the Budget Framework law to enhance budgetary procedures and principles of budgetary management, reinforce accountability, transparency and simplification. [Q4-2013]

3.8. Define in detail the characteristics of the medium-term budgetary framework, including medium-term fiscal strategy, decision-making and prioritisation process, carry-over rules, commitment controls, and appropriate contingency reserves and related access rules after modification of the Budget Framework Law. [April-2013]

\section{Regional and local budgetary frameworks}

3.9. The government will ensure that the measures to implement the new budgetary framework at central government level will also be applied at regional and local level. Adequate structures of monitoring, fiscal reporting, and commitment control will be put into place. [Ongoing]

3.10. The budgetary frameworks at local and regional levels will be considerably strengthened, in line with recommendations by the IMF/EC technical assistance mission of July 2011 and the new EU fiscal policy framework. A draft proposal to revise the regional finance law and the local finance law will be submitted to Parliament by [Q4-2012] ${ }^{5}$. They will include the following main elements:

i. fully adapt the local and regional budgetary frameworks to the principles and rules in the revised Budgetary Framework Law, namely in what concerns (i) the inclusion of all relevant public entities in the perimeter of local and regional government; (ii) the multi-annual framework with expenditure, budget balance and indebtedness rules, and programme budgeting; and (iii) the interaction with the function of the Fiscal Council. The revision will also foresee that: (i) the Fiscal Council reviews regional governments own revenue projections and multi-annual fiscal plans (ii) a contingency reserve is included under the overall current expenditure envelope as a buffer against negative revenue surprises or erroneous expenditure planning, and (iii) the revised legal and institutional PPP framework is applied (see below);

\footnotetext{
${ }^{5}$ Structural benchmark in the Memorandum of Economic and Financial Policies.
} 
ii. strengthen fiscal accountability, in particular by: (i) tighter financial requirements for regional and local SOEs and other regional and local public bodies; (ii) a revision of the regime of transfers between the State and the regions and the local authorities; (iii) strengthening the supervisory power from the State on budgetary execution and (iv) apply tighter debt ceilings combined with the adoption of a multi-tiered monitoring system as suggested by the July 2011 technical assistance mission. This reform should follow international best practices;

iii. limit the scope for lower tax rates in the Autonomous Regions vis-à-vis the rates applied in the mainland and ensure that the resulting additional revenues from increasing the regional rates are used as a priority for fiscal consolidation.

iv. Strengthen the auditing and enforcement powers of the central tax administration to exercise control over the whole territory of the Republic of Portugal including currently exempt tax regimes.

v. Include requirements for data provision to support the revenue projections, balancing the need to preserve tax secrecy and the elaboration of sound forecasts.

3.11. Create a working group with representatives from the Ministry of Finance, the Autonomous Regions and the local authorities to prepare a proposal for common revenue forecasting guidelines for subnational governments. [Q2-2013]

3.12. The Government's financial arrangement with the Autonomous Region of Madeira (RAM), which is in full compliance with the Memorandum of Understanding, will be implemented. The Portuguese Government will monitor progress of implementation by RAM and present the results on a quarterly basis in advance of the reviews of the Memorandum of Understanding [Ongoing].

\section{Public Private Partnerships}

3.13. Following the strategic plan presented by the government, PPP road contracts will be renegotiated in order to obtain substantial fiscal gains, notably in 2013, while ensuring a sustainable reduction in government liabilities. [Ongoing]

3.14. The government will further work towards implementing the PPP framework law and making the new technical unit in the Ministry of Finance fully operational by completing staffing and developing the tools for managing and monitoring all PPPs. No PPP will be launched until the institutional framework measures are fully effective. [Ongoing] Regions will be encouraged to design a similar framework for assessing fiscal risks derived from PPP, concessions and other public investments, as well as for monitoring their execution. [Q4-2012]

3.15. The annual PPP report will provide a comprehensive assessment of the fiscal risks stemming from PPPs and concessions. The report will provide information and analysis at sectoral level and an analysis of credit flows channelled to PPPs through banks (loans and securities other than shares) by industry and an impact assessment on credit allocation and crowding out effects. This particular element will be done in liaison with the Banco de Portugal. The report will serve as input to the fiscal risks assessment for the budget. [Q3-2013] 


\section{State-owned enterprises}

3.16. SOEs with commercial activity will reach operational balance from end of 2012 onwards. This will be achieved by substantially reducing operational costs and raising revenues. To this end the government is implementing the comprehensive SOEs strategy by reviewing the revenue structure and service provision of SOEs, with numerical targets on cost reductions, including measures to realign wages, reduce employment, and additional measures as appropriate. The government is further assessing options for managing the heavy debt load of SOEs, including Parpública. [Ongoing]

3.17. The government submitted to Parliament a draft law to strengthen the governance of SOEs in accordance with international best practices. It reviews the existing shareholder approach, giving the Ministry of Finance a decisive role in financial matters of the enterprises, including monitoring of local SOEs. This will enhance the monitoring powers of the central administration over all SOEs. In addition, the timing and content of financial and operational reporting will be defined. The decisions adopted at central level to improve the efficiency of the enterprises while reducing their financial burden will be implemented at all SOEs, taking into account their specificities. It will include the prohibition for SOEs within the general government to incur new debt with the private sector. No additional SOEs will be created until this law is adopted. [Ongoing]

3.18. Equivalent measures on operational results, debt, restructuring and governance will be taken at the local and regional levels, while respecting their administrative autonomy as foreseen in the law. The annual and quarterly SOEs reports will assess progress towards achieving these objectives for central and local SOEs. Each Autonomous Region will provide similar annual reports. These will serve as inputs to the fiscal risks analysis in the budget. [Ongoing]

\section{Privatisation}

3.19. The government is implementing its privatisation programme under the new framework law for privatisation. The privatisation plan targets front-loaded proceeds of about EUR 5 billion through the end of the programme. The sale of GALP and the small remaining stake in REN on the free market have been delayed until market conditions improve. The privatisation or concession of the cargo handling subsidiary of CP (CP Carga) will be concluded by the [Q2-2013]. The tenders for the privatisation of the national air carrier (TAP) and the airport operator Aeroportos de Portugal (ANA) were launched in the third quarter, with a view to final decisions by end-2012 and the financial completion of these transactions in early 2013. The privatisation of Correios de Portugal (CTT) will be launched, once changes underway in regulation of this sector have their full impact, in order to complete the sale in 2013. The sale or concession of a television channel and radio station belonging to RTP and concessions for transport operators in Lisbon and Porto upon completion of restructuring of the public transport firms in these cities are being considered. CGD's health insurance will be sold in 2012 and the process to sell its insurance arm (Caixa Seguros) to a final buyer is ongoing. The privatisation programme will be expanded to include additional companies and assets for sale or concession in 2013. 
3.20. With a view to introducing private capital and management in the water company Águas de Portugal (AdP), a strategy will be prepared. This strategy will include considerations of the competitive and regulatory environment and organisational consequences. [Q4-2012]

3.21. The government is working together with the municipalities and regional governments in order to identify the scope for further privatisation, by preparing an inventory of their assets, including real estate. [Q4-2012]

\section{Revenue administration}

3.22. The Government will conclude the implementation of the undergone merger of the tax administration, customs administration and the information technology service (DGITA) in a single entity, Autoridade Tributária e Aduaneira (AT) by Q4-2012.

3.23. The reform of the AT will be deepened in $\mathbf{2 0 1 3}$ by targeting a business function-type structure. In particular, the following elements will be implemented:

i. $\quad$ reduce the number of municipal offices by at least 25 per cent in 2013 [Q4-2013] and 25 per cent in 2014 [Q2-2014]];

ii. increase in the resources devoted to auditing in the tax administration to at least 30 per cent of the total staff, mostly through reallocations of staff within the tax administration and other parts of the public administration. The threshold should be attained by Q4-2012;

iii. $\quad$ publish quarterly reports on duration and costs of tax cases starting from Q4-2013 within four months after the end of the relevant quarter.

3.24. To strengthen control and simplify compliance, exchange of information between the collection units of the Tax Authority and the Social Security administration will be significantly strengthened by means, among others, of a unified monthly tax return covering withholding information [Q1-2013] as well as a unified form on Independent Workers' annual revenue [Q22013].

3.25. The government will address the bottlenecks in the tax appeal system by progressing with clearing cases worth more than EUR 1 million [Q4-2012] with the support of the tax court judges.

3.26. Also as part of the development of a modern tax compliance management framework, a fully-fledged Large Taxpayer Office (LTO) will be operational by [Q4-2012] ${ }^{6}$.

3.27. With the aim of curving down fraud and evasion, a reform on the VAT invoicing system will enter into force on $1^{\text {st }}$ January 2013. The reform implies mandatory invoicing across all sectors and transactions, a centralized VAT monitoring database, a system to electronically monitor goods in circulation and a tax incentive for final consumers to ask for invoices in hard-to-tax sectors. An evaluation report of the measures will be prepared [Q2-2013].

\footnotetext{
${ }^{6}$ Structural benchmark in the Memorandum of Economic and Financial Policies.
} 
3.28. The authorities will continue to focus on measures to combat fraud and evasion and strengthen taxpayers' compliance. To this end the authorities will:

(i) prepare a report to analyse the current tax compliance situation, including a risk analysis of different economic sectors and categories of taxpayers by the seventh review. Following the results of the report, appropriate steps will be taken if necessary to reinforce tax compliance.

(ii) continue building capacity in revenue administration by phasing in a more modern approach to managing compliance over a three-years period.

\section{Public administration}

Central, regional and local administration

3.29. The government will monitor and promote streamlining of foundations at the local and regional level. [Ongoing]

3.30. Review the regulation on the creation and the functioning of associations and observatories. The revised regulation will also facilitate the closure of existing associations and observatories and define the monitoring and reporting mechanisms to be put in place. [Q2-2013]

3.31. Building on the study by the inter-ministerial working group for territorial issues, potential duplications of activities and other inefficiencies between the central administration, local administration and locally-based central administration services will be identified and the existing framework to eliminate the identified inefficiencies reformed. [Q4-2012]

\section{Shared services}

3.32. Develop the use of shared services in the central administration by fully implementing the ongoing projects and by regularly assessing the scope for further integration:

i. complete the implementation of the strategy of shared services in the area of financial resources (GeRFIP). [Q1-2013] GeRFIP will also be implemented in the Autonomous Region of Madeira and in the Autonomous Region of Azores [Q42013];

ii. fully implement the strategy of shared services in the area of human resources (GeRHuP) in the Ministry of Finance's entities [Q4-2012], with the exception of the Tax Authority for which this is scheduled for end-June 2013. Other Ministries will follow in 2013. The Autonomous Region of Madeira will implement GeRHuP gradually;

iii. rationalise the use of IT resources within the central administration by implementing shared services and reducing the number of IT entities in individual Ministries or other public entities in line with the "Overall Strategic plan to rationalise and reduce costs on ICT in Public Administration". [Q4-2012] 
3.33. Reduce the number of local branches of line ministries (e.g. tax, social security, justice). The services should be merged in citizens' shops covering a greater geographical area and developing further the e-administration over the duration of the programme. [Q4-2013]

\section{Human resources}

3.34. Limit staff admissions in public administration to achieve annual decreases in 2012-2014 of at least 2 per cent per year (in full-time equivalents) in the staff of central administration and 2 per cent in local and regional administrations (in full-time equivalents); including a significant reduction of fixed-term contracts. The government will ensure the implementation of this measure at local administration level and will promote the initiatives needed so that each region will present its plan to achieve the same target. [Ongoing]

3.35. The government will present a comprehensive review of wage scales in the general government, to identify unwarranted differences in remuneration between the public and the private sector for similar types of qualifications. [Q4-2012] The comprehensive study of SOEs will follow in Q2-2013.

3.36. Accelerate the convergence of the system of social protection for staff that are in the Regime de Proteção Social Convergente (RPSC) to the rules of Regime Geral de Segurança Social. [Q4-2013]

3.37. The Special Mobility scheme will be reviewed aiming at being more oriented to support Public Administration Reform, addressing training and requalification for a better allocation of Human Resources. The existing Special Mobility Law need to be revised: (i) to ease/simplify the procedures for the management of the employees that can be targeted with this tool; (ii) to address the compensation that would be set to decline further over time and its duration; and (iii) to be applied to all sectors of Public Administration, including teachers and health professionals. [Q22013]

\section{Health care system}

\section{Objectives}

Improve efficiency and effectiveness in the health care system, inducing a more rational use of services and control of expenditures; generate additional savings in the area of pharmaceuticals to reduce the overall public spending on pharmaceutical to 1.25 percent of GDP by end 2012 and to about 1 per cent of GDP in 2013; generate additional savings in hospital operating costs and devise a strategy to eliminate arrears.

The government will take the following measures to reform the health system:

\section{Financing}

3.38. The revision of NHS moderating fees (taxas moderadoras) and improvements in the billing and collection of payments from insurance companies and fees for the treatment of crossborder/foreign patients will result in additional revenues of EUR 150 million in 2012 and an additional 50 million in 2013. [Q4-2012] 
3.39. In the light of the urgency and size of the savings needed in the health sector to address large arrears and budget limitations, plans to achieve a self-sustainable model for health-benefits schemes for civil servants will be accelerated. The current plan foresees that the overall budgetary cost of existing schemes - ADSE, ADM (Armed Forces) and SAD (Police Services) - will be reduced by 50 per cent of the employers contribution in 2013 through transfer of resources to the NHS in exchange for the provision of services by Q4-2012. The employer's contribution rate will be reduced to $1.25 \%$ in 2014 and will be accompanied by an adjustment in the scope of health benefits [Q32013]. The system would become self-financed by 2016.

Pricing and reimbursement of pharmaceuticals

3.40. Enact legislation which automatically reduces the prices of medicines when their patent expires to 50 per cent of their previous price. [Q4-2012]

3.41. The government implements an annual revision of prices of medicines and of countries of reference in order to achieve cost savings. Second price revision to be published in January 2013.

3.42. The government will monitor monthly pharmaceutical expenditures and ensure that the overall public pharmaceutical expenditure does not exceed the target of 1.25 per cent of GDP in 2012 and 1 per cent of GDP in 2013. [Ongoing]

\section{Prescription and monitoring of prescription}

3.43. Continue to improve the monitoring and assessment system of doctors' prescription behaviour regarding medicines and diagnostic in terms of volume and value and vis-à-vis prescription guidelines and peers. Feedback continues to be provided to each physician on a regular basis (e.g. quarterly), in particular on prescription of costliest and most used medicines. [Ongoing]

3.44. Continue to devise and enforce a system of sanctions and penalties, as a complement to the assessment framework [Ongoing]. Assess the possibility of establishing agreements with private sector physicians for the application of prescription rules as applied in the NHS.

3.45. Strictly monitor the implementation of the legislation making it compulsory for physicians at all levels of the system, both public and private, to prescribe by International Non-proprietary Name (INN) to increase the use of generic medicines and the less costly available product. An implementation report will be published by December 2012.

3.46. Continue to publish prescription guidelines with reference to medicines and the realisation of complementary diagnostic exams on the basis of international prescription guidelines, audit their implementation and integrate them in the electronic prescription system. A first set of guidelines is introduced in the e-prescription system by Q2 2013.

3.47. The government will produce a report assessing the effectiveness of the enacted legislation aimed at removing all effective entry barriers for generic medicines, in particular by reducing administrative/legal hurdles in order to speed up the use and reimbursement of generics. [Q12013]

3.48. The above measures should aim at gradually and substantially increasing the share of generic medicines to at least 30 per cent of all outpatient prescription (in volume) in 2012. In 2013 
the target for NHS reimbursed medicines will be $45 \%$ of all outpatient prescription (in volume) and will increase to $60 \%$ in 2014.

\section{Centralised purchasing and procurement}

3.49. Reinforce the centralised acquisition of vehicles, utilities, external services and other cross functional goods and services by all entities included in the NHS, in order to reduce costs through price volume agreements and fighting waste. A detailed action plan will be published by November 2012.

3.50. INFARMED will continue implementing the uniform coding system and a common registry for medical supplies. [Ongoing]

3.51. Reduce by an additional 10 percent the overall spending of the NHS with private providers delivering diagnostic and therapeutic services (with particular reference to dialysis and rehabilitation). Regularly evaluate and if necessary revise (at least every two years) the remuneration paid to private providers with the aim of reducing the cost of more mature diagnostic and therapeutic services. [Q4-2012]

3.52. Implement the centralised purchasing of medical goods through the recently created Central Purchasing Authority (SPMS), using the uniform coding system for medical supplies and pharmaceuticals. Continue to implement the compulsory use of a formulary in all hospitals to monitor the stock and flows of hospital medicines and medical supplies and monitor compliance with central purchasing. [Ongoing]

3.53. Take further measures to increase competition among private providers and between private and public providers in relevant areas of service provision such as dialysis and the pharmacies sector in view of ensuring competition and fair prices in private markets. [Q4-2013]

\section{Primary care services}

3.54. As part of the reorganisation of health services provision and notably the concentration and specialisation of hospital services and the further development of a cost-effective primary care service, the Government reinforces measures aimed at further reducing unnecessary visits to specialists and emergencies and improving care coordination. [Ongoing] This will be done through:

i. $\quad$ increasing the number of USF (Unidades de Saúde Familiares) units contracting with regional authorities (ARSs) using a mix of salary and performance-related payments as currently the case. Extend performance assessment to the other primary care units (UCSPs). Make sure that the new system leads to a reduction in costs and more effective provision;

ii. setting-up a mechanism to guarantee the presence of family doctors in needed areas to induce a more even distribution of family doctors across the country;

iii. moving human resources from hospital settings to primary care settings and reconsidering the role of nurses and other specialties in the provision of services; 
iv. updating patients' registration lists and the national register in order to increase by at least 20 per cent the maximum number of patients per primary care/family doctor for health centres and by 10 per cent for the USF.

\section{Hospital services}

3.55. Implement the strategy to clear arrears in the health sector, within the overall strategy for settling and avoiding the re-emergence of arrears. Ensure standardised and tight control procedures for all health sector entities to ensure expenditure commitments stay within the budget allocated to each entity and therefore prevent the re-emergence of arrears. [Q4-2012]

3.56. Hospital SOEs will change the existing accounting framework and adopt accounting standards and appropriate IT systems in line with the requirements for private companies and other SOEs. This will help improving the management of the enterprises and the quality of the financial oversight by the general government. [Q4-2013]

3.57. Implement measures aimed at achieving a reduction of at least EUR 200 million in the operational costs of hospitals in 2012. This is to be achieved through the reduction in the number of management staff, concentration and rationalisation in state hospitals and health centres with a view to reducing capacity. [Q4-2012]

3.58. Continue the publication of clinical guidelines and set in place an auditing system of their implementation. [Ongoing]

3.59. On the basis of the comprehensive set of indicators, produce regular annual reports comparing hospital performance (benchmarking). Establish a web-portal with publicly available information. The first report is to be published by end 2012 and its results should be used to establish targets for less performing hospitals. [Q4-2012]

3.60. Continue work to ensure full interoperability of IT systems in hospitals, in order for the ACSS to gather real time information on hospital accounting and activities and to produce monthly reports to the Ministry of Health and the Ministry of Finance. [Ongoing]

3.61. Continue with the reorganisation and rationalisation of the hospital network through specialisation, concentration and downsizing of hospital services, joint management (building on the Decree-Law 30/2011) and joint operation of hospitals. The aim is to adjust hospital provision within the same health region, notably in the presence of newly established PPP hospitals, adjust the activity of some hospitals from curative care towards areas such as rehabilitation, long-term and palliative care and revise emergency and transplantation structures. These improvements aim at eliminating unnecessary duplication, achieving economies of scale and deliver additional cuts in operating costs by at least 5 percent in 2013 while improving the quality of care provided. A detailed action plan is published by $\mathbf{3 0}$ November 2012 and its implementation is finalised by end-2013. Overall, from 2011 to 2013, hospital operational costs must be reduced by at least 15 per cent compared to 2010 level. [Q4-2012]

3.62. Annually update the inventory of all health staff and prepare regular annual reports presenting plans for the allocation of human resources in the period up to 2014. The report specifies plans to reallocate qualified and support staff within the NHS. [Q2-2013] 
3.63. Update the current legal framework applying to the organisation of working time of healthcare staff, including introduction of rules to increase mobility within and across Health Regions, adoption of flexible time arrangements and review of payment mechanisms for emergency work, the prevention regime and per call payments, notably by aligning overtime remuneration in the health care sector with the general legal framework recently adopted. In this context, overtime compensation should be reduced by $20 \%$ in 2012 and another 20\% in 2013.[Q4-2012].

Regional health authorities

3.64. Improve monitoring, internal control and fiscal risks management systems of the Administrações Regionais de Saúde. [Q4-2012]

Cross services

3.65. Continue to develop the system of patient electronic medical records and ensure access to all relevant health care facilities. [Ongoing]

3.66. Reduce costs for patient transportation by one third compared to 2010. [Q4-2012]

\section{Labour market and education}

\section{Labour market}

\section{Objectives}

Revise the unemployment insurance system to reduce the risk of long-term unemployment while strengthening social safety nets; reform employment protection legislation to tackle labour market segmentation, foster job creation, and ease the transition of workers across occupations, firms, and sectors; ease working time arrangements to contain employment fluctuations over the cycle, better accommodate differences in work patterns across sectors and firms, and enhance firms' competitiveness; promote labour cost developments consistent with job creation and enhanced competitiveness; ensure good practices and appropriate resources to Active Labour Market Policies to improve the employability of the young and disadvantaged categories and ease labour market mismatches.

Address early school leaving and improve the quality of secondary education and vocational education and training, with a view to raising the quality of human capital and facilitate labour market matching.

Reforms in labour and social security legislation will be implemented after consultation with social partners, taking into account possible constitutional implications, and in respect of EU Directives and Core Labour Standards.

Unemployment benefits

4.1. Following the reform of the unemployment benefit system (Decree-law 64/2012 and Decree-law 65/2012 of 15 March) - which introduces a declining profile for unemployment benefits, reduces the maximum monthly amount of benefits, reduces the maximum unemployment benefits duration and increases coverage by reducing the contribution period for eligibility and by extending the system to a clearly-defined category of self-employed - the government will prepare by Q4- 
2012 an analysis on benefit dependency and long-term unemployment with a view to assessing whether further measures are needed to address possible deficiencies by Q1-2013.

\section{Employment protection legislation}

4.2. The government will carry out reforms in the employment protection system aimed at tackling labour market segmentation, fostering job creation, and easing adjustment in the labour market. [Ongoing]

4.3. Severance payments [Ongoing]. Following the entry into force of law $n$. 53/2011 concerning the reform in the severance payments for new hires in line with the $\mathrm{MoU}$ and the entry into force of law n. 23/2012, the government will further reduce severance payments. In consultation with social partners, the Government will:

- submit to Parliament by mid-December draft legislation aiming at aligning the level of severance payments with the EU average of 12 days, applied to all contracts while protecting accrued-to-date entitlements and maintain the cap of 12 month of pay;

- consider the implementation of a compensation fund for severance payments possibly allowing the severance pay entitlements financed from the fund to be transferable to different employers.

4.4. Following the changes to the dismissal rules as stated in law n. 23/2012, the government will prepare a report on the effects of these changes on relevant labour market indicators by Q3-2013.

Wage setting and competitiveness

4.5. The government will promote wage developments consistent with the objectives of fostering job creation and improving firms' competitiveness with a view to correcting macroeconomic imbalances. To that purpose, the government will:

i. commit that, over the programme period, any increase in the minimum wage will take place only if justified by economic and labour market developments and agreed in the framework of the programme review [Ongoing];

ii. ensure wage moderation when deciding on the extension of collective agreements that fulfil the criteria set out in Council of Ministers Resolution 90/2012, by taking into account the implications of the extension on competitiveness of non-affiliated firms [Ongoing];

iii. prepare an independent review by Q4-2012 on:

- how the tripartite concentration on wages can be reinvigorated with a view to defining norms for overall wage developments that take into account the evolution of the competitive position of the economy and a system for monitoring compliance with such norms;

- the desirability of shortening the survival (sobrevigência) of contracts that are expired but not renewed (art 501 of the Labour Code). 
4.6. The Government will promote wage adjustments in line with productivity at the firm level. Following the implementation of the organised decentralisation (which creates the possibility for collective agreements to define conditions under which works councils can negotiate functional and geographical mobility, working time arrangements and remuneration) and the decrease of the firm size threshold to 150 workers for unions to delegate power to conclude collective agreements to works councils, the government will, by Q1-2013, assess in a report the effects of these measures and how they are being applied in collective agreements. If needed, an action plan will be prepared in consultation with the social partners by Q2-2013 to ensure that works councils are given the possibility to negotiate wages at firm level.

Active labour market policies

4.7. The Government will ensure good practices and an efficient amount of resources to activation policies to strengthen job search effort by the unemployed and to other Active Labour Market Policies (ALMPs) to improve the employability of the young and disadvantaged categories and ease labour market mismatches. Following the preparation of a report assessing the effectiveness of ALMPs and the publication of the Council of Ministers Resolution n.20/2012, which sets a plan to improve ALMPs, including the role of Public Employment Services (PES) , the Government by Q4-2012 will present a report:

i. detailing expenditures and sources of financing of the different ALMPs;

ii. assessing the role played by the job counselling/ job search assistance and activation/sanctions systems in facilitating the transition out of unemployment;

iii. reviewing the implementation of the Council of Ministers Resolution n. 20/2012 regarding the reorganisation of the PES and other ALMPs;

iv. proposing specific action to improve the effectiveness of training measures in light of the results of the report assessing the effectiveness of employment and training measures.

\section{Education and training}

4.8. The government will continue action to tackle low education attainment and early school leaving and to improve the quality of secondary education and vocational education and training, with a view to increase efficiency in the education sector, raise the quality of human capital and facilitate labour market matching. To this purpose, the government will:

i. set up an analysis, monitoring, assessment and reporting system in order to accurately evaluate the results and impacts of education and training policies, notably plans already implemented (notably concerning cost saving measures, vocational education and training and policies to improve school results and contain early school leaving). The tool should be fully operational by Q2-2013;

ii. in line with the action plan to improve the quality of secondary education the Government will: (i) continue to promote trust agreements with public schools and report about progress [ongoing]; (ii) define and implement a simple formula-based funding framework comprising performance evaluation criteria and accountability 
for public schools and schools under autonomy agreements [Q4-2012]; (iii) present an assessment of the new inspection model, including the planned follow up to recommendations of previous external evaluations [Q4-2012];

iii. in line with action plan on vocational and educational training (VET) the Government will report on: (i) involvement of businesses in the provisions of traineeships [ongoing]; (ii) action taken to reorganise modalities for the provision of VET, improve the quality and attractiveness of VET, and to enhance students' orientation and career guidance [Q4-2012]; (iii) the establishment of "professional schools of reference". [Q1-2013]

iv. present an assessment on the latest developments in the apprenticeship system. [Q1-2013]

\section{Goods and services markets}

\section{Objectives}

Reduce entry barriers in network industries and sheltered sectors of the economy such as services and regulated professions so as to increase competition and reduce excessive rents. These measures should help improving the competitiveness of the Portuguese economy by lowering input prices, raising productivity and improving the quality of the products and services provided. This should contribute decisively to the social balance of the programme by reducing unwarranted sector protection and rents so that all segments of the society participate in the burden sharing of the needed adjustment.

\section{Energy markets}

\section{Objectives}

Complete the liberalisation of the electricity and gas markets; ensure the sustainability of the national electricity system and avoid further unfavourable developments in the tariff debt; ensure that the reduction of the energy dependence and the promotion of renewable energies is made in a way that limits the additional costs associated with the production of electricity under the ordinary and special (co-generation and renewables) regimes; ensure consistency of the overall energy policy, reviewing existing instruments. Continue promoting competition in energy markets and to further integrate the Iberian market for electricity and gas (MIBEL and MIBGAS).

\section{Liberalisation of electricity and gas markets}

5.1. In order to fully transpose the Third EU Energy Package: a) adopt the law on the penalty system of the regulator and b) ensure the National Regulatory Authority's independence, autonomy and all powers foreseen in the package by adopting by [November-2012] the new regulators' bylaws agreed in July 2012, consulting the EC/ECB/IMF if changes are introduced. Ensure that the new bylaws are effective before end of year in time for the liberalisation of the electricity and gas market [Q4-2012].

5.2. Take measures to accelerate the establishment of a functioning Iberian market for natural gas (MIBGAS), through regulatory convergence and the harmonisation of the tariff structures in 
Portugal and Spain. In particular, in accordance with the roadmap of 30 September 2011 agreed with the Spanish authorities, the regulators of each country will:

i. present proposals to harmonise the tariffs for access to the interconnection networks taking into account the outcome of the public consultation conducted in January 2012 [Q1-2013];

ii. prepare a report analysing and developing options to improve the harmonised mechanism for capacity allocation and congestion management of cross-border flows with Spain, including the introduction of virtual reverse flows and other mechanisms allowing smaller players to make efficient use of the LNG Sines facility [Q4-2012];

iii. apply a harmonised allocation and congestion management mechanism to all the interconnection capacity between Portugal and Spain, in line with the EU network codes and guidelines in this respect [Q1-2013].

5.3. Clarify the national legal framework with respect to the scope of competencies of the logistics operator and define based on a cost-benefit analysis a way of convergence of the existing two platforms for electricity and natural gas. [Q4-2012]

Ensure sustainability of the national electricity system

5.4. Conclude the measures approved in the Council of Ministers on 17 May 2012 to reduce excessive rents and to address the sustainability of the national electricity system. Cost reduction measures address the following compensation schemes: power guarantee, special regime (renewables - excluding those granted under tender mechanisms - and cogeneration), CAE's (power purchase agreements) and CMECs, and will reduce policy cost by at least EUR 1275 million in Net Present Value (NPV) ${ }^{7}$ [Q4-2012]. The updated estimation of cost reductions that will be achieved as well as progress towards elimination of the tariff debt (dívida tarifária) by 2020 will be presented and assessed in the seventh review.

5.5. Conclude the announced measures to limit the policy costs embedded in CMECs and PPAs by Q4 2012. In particular, as an element in revising the rate of return to bring it in line with the cost of capital at the moment the CMEC compensation was defined plus, if warranted, a risk premium of the assets that the mechanism remunerates: (i) approve the pieces of legislation that reduce the CMEC annuity discount rate from $7.55 \%$ to below $5 \%$ in terms that do not allow the increase of the new established rate (yielding a NPV of EUR 120 million); and (ii) set a compensation for the extension of exploitation licences of the power plants in Sines and Pego ${ }^{8}$ yielding NPVs of EUR 5575 million and EUR 30-50 million respectively, providing details on the valuation methodology leading to these figures. The updated estimation of cost reductions that will be achieved will be presented and assessed in the seventh review.

\footnotetext{
${ }^{7}$ Computed using a discount rate of $7.55 \%$ back to June 2012.

${ }^{8}$ Pego power plant compensation will not be included when determining the reduction of the rate of return of the CMEC.
} 
5.6. Present a report on the CMEC scheme including the foreseen annual compensation amounts to each beneficiary and past payments since 2007 and the forecast of future payments. The report will also describe the process for the extension of the concession of the public hydro resource by the former CAE hydro power plants, its correspondent economic valuation, and the rationale for the direct award instead of a tender process. The report will assess and consider all the information available within the governmental and the official bodies (General Directorates, Regulator, State representative in the contracts). [Q4-2012]

5.7. Conclude the announced measures to limit the policy costs of renewables under the special regime - excluding those granted under tender mechanisms by [Q4-2012]. In particular (i) following the agreement in principle with wind power producers, approve the legislation to implement the compensation to be paid by the producers (yielding a NPV of EUR 110 million); and (ii) introduce a maximum duration for the feed in tariff in small hydro plants (yielding an NPV of EUR 200 to 250 million). The updated estimation of cost reductions that will be achieved will be presented and assessed in the seventh review.

5.8. Accelerate convergence to market-based pricing for co-generation operators in parallel with electricity market developments under the EU internal electricity and gas market legislation. The remuneration scheme for co-generation will be further revised to improve efficiency of the support system in ensuring continued guaranteed access of operators to electricity networks and markets with the calculation of explicit subsidies based on relevant price factors in the context of a competitive electricity market. The revision should ensure that the design of the support scheme allows a dynamic correlation between electricity market prices and the efficiency premium when the values of avoided externalities are not adequately reflected in electricity and other factor prices. This revision will be undertaken in line with the framework of the transposition of the energy efficiency directive [Q1-2013]. Ensure through annual audits that plants not fulfilling the requirements for cogeneration do not receive the support, and report on the progress. [Q2-2013]

5.9. For new contracts in renewables, revise downward the feed-in tariffs and ensure that the tariffs do not over-compensate producers for their costs and they continue to provide an incentive to reduce costs further, through digressive tariffs. For more mature technologies develop alternative mechanisms (such as feed-in premiums). Report on action taken will be provided in Q3-2013.

5.10. Decisions on future investments in renewables, in particular in less mature technologies, will be based on a rigorous analysis in terms of its costs and consequences for energy prices. International benchmarks will be used for the analysis and an independent evaluation will be carried out. Report on action taken will be provided in Q3-2013.

\section{$\underline{\text { Telecommunications and postal services }}$}

\section{Objectives}

Increase competition in the market by lowering entry barriers; guarantee access to network/infrastructure; strengthen power of the National Regulator Authority. 


\section{Telecommunications}

5.11. Ensure an efficient, objective, transparent and non-discriminatory mechanism for the designation of the universal service provider(s), in compliance with the Court of Justice ruling of 7 October 2010. Re-negotiate the concession contract with the undertaking currently providing the universal service, by reducing the scope of the services covered, so as to exclude the universal service and following the launch of a new tender process in October, proceed with the designation of universal service provider(s). [Q2-2013]

5.12. Following the corrective measures already taken, monitor the competitive situation in the telecommunications sector, in particular wholesale and retail broadband access, and mobile origination charges. [Ongoing]

\section{Postal services}

5.13. Following the transposition of the Third Postal directive, further liberalise the postal sector by amending the decree-law laying down the framework of the concession contract and renegotiating the amendment of said contract with CTT, in order to reflect the new law (Law 17/2012) transposing the Third Postal Directive; ensuring in particular that the current designation period for the universal service provision is shortened to 2020 and that investment needs and return on investment are taken into account when setting new designation periods. [Q4-2012]

\section{Transport}

Adopt a strategic plan to: rationalise networks and improve mobility and logistic conditions in Portugal; improve energy efficiency and reduce environmental impact; reduce transport costs and ensure financial sustainability of the companies; strengthen competition in the railways sector and attract more traffic; integrate ports into the overall logistic and transport system, and make them more competitive.

\section{Strategic Plan for Transport}

5.14. Implement the Strategic Plan for Transport for 2011-2015 [Q4-2012], namely:

i. continue the reforms in the transport SOEs to achieve their EBITDA balance, by focusing efforts on the reduction of operational costs;

ii. reduce the forecast debt burden of Estradas de Portugal through the reduction of PPP contracts' scope still in the construction phase, revision of shadow-toll schemes and the adjustment of the CSR (Road Service Contribution) to the inflation level. Analyse additional measures to further reduce the forecast debt burden of Estradas de Portugal;

iii. focus the investment priorities in projects that present a positive cost-benefit ratio and contribute to the competitiveness of Portuguese exports, namely in the port and freight rail sectors;

iv. reform the transport and infrastructures' regulatory framework in order to improve the effectiveness, efficiency and independence of the entities regulating the transport sector. [Q1-2013] 
5.15. Present a long term vision of the transport system and a list of actions to improve its efficiency and sustainability [Q4-2012]. It will specifically include an assessment of the existing rail, road and port networks and present a set of investment priorities for the 2020 and 2030 horizons, taking also into account TEN-T networks, with an estimate of the financial needs and the foreseen sources of financing [Q2-2013].

Railways sector

5.16. Continue with the transposition of the EU Railway Packages and in particular:

i. ensure that the rail regulator enjoys the independence required under the EU rail Directives, in particular regarding the rules of appointment and dismissal of the director of the rail regulator. Strengthen the capacities of the railway regulator to fulfil its regulatory mandate effectively, including by exploring synergies with other transport regulators in the context of the revision of national regulatory agencies. [Q1-2013];

ii. continue to implement the plans to bring the infrastructure manager to operational balance, in particular by reducing operational costs by at least 23 per cent in 2012 compared to 2010 [Q4-2012]. On the revenue side, track access charges for freight services should not be increased in order to prevent a deterioration of the competitiveness of rail freight services. Reintroduce incentives to REFER to reduce costs and access charges. Provide annual progress reports on the implementation of balancing revenues and expenditures [Q2-2013];

iii. ensure that the new Public Service Obligation (PSO) contracts concluded on rail passenger transport respect EU legislation including Regulation (EC) No $1370 / 2007$, and in particular provide a detailed breakdown of state contributions for each line under PSO. Develop administrative capacity for a stepwise introduction of competitive tendering of PSOs starting with some suburban services. Ensure that the awarding authority has the required level of independence and competence and guarantees fair conditions of tendering [Q42012];

iv. extend the performance scheme on infrastructure charges to other operators [Q42012];

v. review and render more effective the yield management on long-distance passenger ticket prices. [Q1-2013];

vi. to prepare the privatisation of the freight branch of the state-owned rail operator, carry out an analysis for transferring part or whole of CP Carga's rolling stock to a rolling stock operating company [Q2-2013];

vii. ensure that the main rail terminals currently owned by CP Carga are transferred to another entity that will guarantee non-discriminatory access to all rail freight operators. [Q4-2012]. 
Ports

5.17. Adopt the revised legal framework governing port work as presented to Parliament by [Q42012]. A review of the overall savings generated and the impact of the introduction of the law on port usage cost will be made by August 2013.

5.18. Take further steps to improve the governance model of the ports system with the objective to enhance the competitiveness and the efficiency of ports in line with the Strategic Plan of Transport 2011-2015. The Government will deliver and enforce policies that ensure strong integrated policy-making, strategic planning and surveillance functions common to all ports in the country. Moreover, policy decisions will be taken and enforced so that (i) efficiency gains and costsavings are passed through to port customers; and (ii) concession-holders of terminals and land facilities in ports respect minimum performance criteria. [Q4-2012]

Road pricing

5.19. Adopt the necessary legislative amendments in order to achieve full compliance with Directive 1999/62/EC (Eurovignette Directive) and the EU Treaty and, in particular, to guarantee nondiscriminatory application of tolling schemes to non-resident road users [Q4-2012]. After the deadline of this measure, rebates in tolling schemes that pursue compelling reasons of territorial and social cohesion may only be applied if their compliance with the EU law is demonstrated.

\section{Other services sector}

\section{Objectives}

Eliminate entry barriers in order to increase competition in the services sector; soften existing authorisation requirements that hinder adjustment capacity and labour mobility; reduce administrative burden that imposes unnecessary costs on firms and hamper their ability to react to market conditions.

Sector-specific legislation of Services

5.20. Further to the adoption of a significant number of amendments to the sector specific legislation, complete the adoption of the outstanding sectorial amendments (such as construction, universities and higher education courses) necessary to fully implement the Services Directive and submit them to Parliament where necessary by [Q4-2012] in view of approval by [Q1-2013]. For those amendments already submitted to the Parliament (such as real estate) approval is expected by [Q4-2012].

\section{Regulated professions}

5.21. Review and reduce the number of regulated professions and in particular eliminate reserves of activities on regulated professions that are no longer justified, through adoption by the Parliament of the law for professions where regulation does not involve a professional body (Ordens or Câmaras) by [Q4-2012]. Following the final report by the Comissão de Regulação do Acesso a Profissões (CRAP), launch by [Q1-2013] a second phase investigation of the review of regulated professions to eliminate unjustified requirements by [Q2-2013]. 
5.22. Further improve the functioning of the regulated professions (such as accountants, lawyers, notaries) for which regulation involves a professional body (Ordens or Câmaras) by (i) carrying out a comprehensive review of requirements affecting the exercise of activity with a view to eliminating those not justified or proportional, such as those restrictions to the use of commercial communication (advertising) prohibited by the Services Directive, and (ii) by adopting measures to further improve the recognition of professional qualifications in compliance with the Professional Qualifications Directive To achieve the objectives referred to above the government has, following the public consultation, submitted a draft horizontal legal framework to Parliament in view of approval by [Q4-2012]. Upon enactment, the professional bodies will make the necessary changes in their statutes by [Q1-2013].

\section{Administrative burden}

5.23. Continue the simplification reform effort by:

i. adapting the content and information available at the Point of Single Contact (PSC) for the 48 amended regimes to ensure conformity with the Services Directive and for those that have not required amendments so far by [January 2013] and make available online forms for the completion of procedures by [Q1-2013]. Constantly adapting the content and information available at the PSC to the remaining 20 sector-specific regimes that are about to be adopted to ensure conformity with the Services Directive (see 5.20 above) at the latest 1 month after the adoption of each sector-specific regime, clearly differentiating information on requirements applicable to established providers and to cross-border ones, and by making available online forms and extend on-line procedures for all sectors covered by the Services Directive no later than 2 months after adoption of the sector-specific regime;

ii. adapting the content and information available at the PSC for the 15 regimes approved to ensure conformity with the Professional Qualifications Directive by [January 2013] and online forms by [Q1-2013]. Constantly adapting the content and information available at the PSC to the new legislation to be adopted to ensure conformity with the Professional Qualifications Directive at the latest 1 month after the adoption of amendments, clearly differentiating information on requirements applicable to established providers and to cross-border ones, and by extending online forms and procedures for each profession no later than 2 months after adoption of amendments;

iii. making available in PSC on-line procedures for the registration, installation, modification, occupation of public space regimes, and closing up of restaurants, bars and other establishment for the 5 municipalities (Porto, Águeda, Abrantes, Portalegre and Palmela) covered by "Zero Authorisation" pilot project (DL 48/2011) by [Q4-2012]. Foster collaboration from municipalities in providing the content for the working hours map for the stores and establishments services and advertisement regimes for which they have full competence to make the PSC operational [Q42012]; Identify and classify municipalities where the availability of those procedures through the PSC would have the most significant economic impact by [November- 
2012] to prepare for the extension of this tool to major municipalities by [January2013]. Make fully operational the "Zero Authorisation" project that abolishes authorisations/licensing and substitute them with a declaration to the PSC for the wholesale and retail sector and restaurants and bars by [Q2-2013]. The platform will be available to all levels of administration, including all municipalities [Q2-2013];

iv. extending PSC to services not covered by the Services Directive [Q4-2013];

v. extending the "Zero Authorisation" project to other services sectors of the economy [Q4-2013].

5.24. Provide a monthly update of the detailed work programme of AMA to fulfil 5.23.

\section{Housing market}

\section{Objectives}

Improve access to housing; foster labour mobility; improve the quality of housing and make better use of the housing stock; reduce the incentives for households to build up debt.

\section{Property taxation}

6.1. The government will continue to step up the appraisal of the taxable value of the housing stock. In particular, the measures will: (i) ensure that the taxable value of the properties in 2012 is close to the market value and (ii) property valuation is updated regularly (every year for commercial real estate and once every three years for residential real estate as foreseen in the law).

6.2. The government will gradually rebalance property taxation towards the recurrent real estate tax (IMI) and away from the transfer tax (IMT), while considering the socially vulnerable. [Q3-2013]

Comprehensive review of the housing market

6.3. Following the adoption of the amendments to the New Urban Lease Act Law 6/2006 and the Decree Law which simplifies the administrative procedures for renovation, the government will undertake a comprehensive review of the functioning of the housing market with the support of internationally-reputed experts. The review will determine whether the new legal provisions adopted are sufficient to make the housing market more dynamic and, if necessary, will propose new policy measures. [Q2-2013]

\section{Framework conditions}

\section{Judicial system}

\section{Objectives}

Improve the functioning of the judicial system, which is essential for the proper and fair functioning of the economy, through: (i) ensuring effective and timely enforcement of contracts and competition rules; (ii) increasing efficiency by restructuring the court system, and adopting new court management models; (iii) reducing slowness of the system by eliminating backlog of courts cases and by facilitating out-of-court settlement mechanisms. 


\section{Court backlog}

Recognising the urgency of the judicial reform to make the judicial system more efficient and more effective, the government will:

\subsection{Aim to resolve the backlog of court cases by Q2-2013.}

7.2. Implement targeted measures to achieve steady reduction of the backlogged enforcement cases. In particular, set quarterly targets for closing enforcement cases and prepare quarterly reports on implementation status, by inter-agency task forces with the fifth report to be completed by mid-

\section{February 2013.}

7.3. Present a revised draft bill for enforcement agent's framework (i) strengthening the authority and financing structure of the oversight body and enhancing the accountability of enforcement agents, and (ii) to include a fee structure that incentivises speedy enforcement which will be approved by the government by end-February 2013.

7.4. Publish quarterly reports on recovery rates, duration and costs of corporate insolvency cases starting from [Q3-2011], within four months after the end of the relevant quarter.

\section{Competition, public procurement and business environment}

\section{Objectives}

Ensure a level playing field and minimise rent-seeking behaviour by strengthening competition and sectoral regulators; eliminate special rights of the state in private companies (golden shares); reduce administrative burdens on companies; ensure fair public procurement processes; improve effectiveness of existing instruments dealing with export promotion and access to finance and support the reallocation of resources towards the tradable sector.

\section{Competition and sectoral regulators}

7.5. The Government shall take the necessary measures to ensure that the Portuguese State or any public bodies do not conclude, in a shareholder capacity, shareholder agreements the intention or effect of which hinder the free movement of capital or which influence the management or control of companies [Ongoing]. The Portuguese State will ensure that CGD alienates its participation in Galp. [Q4-2012]

7.6. Going beyond elimination of special rights of the State, the authorities also commit to ensure that obstacles to free movement of capital will not be created by their action. The authorities acknowledge that the discretion granted under the amended article 13(2) of the Framework Law of Privatisations (Law 11/90 amended by Decree 3/XII of the Parliament of 5 August 2011), if used, shall be restricted solely to the concrete privatisation operation and thus used in such a proportionate manner that privatisation's implementing laws will not set or allow holding or acquisition caps beyond the privatisation transaction. [Ongoing]

7.7. Monitor the inflow of cases and report on the functioning of the specialised court for Competition, Regulation and Supervision, assessing the situation in terms of risk of potential court backlogs. [Q4-2012] 
7.8. Take the necessary actions to ensure the effective functioning of the Competition Authority financing model [Q4-2012]. Following the efforts made in order to guarantee the enlarged scope of action of the Competition Authority, report on the conditions for the proper execution of its mandate [Q4-2012].

7.9. Building on the independent report on the main National Regulator Authorities, the government will prepare a framework law for regulators in broad consultation with the Regulator Authorities. This law will establish a regulatory environment that protects the public interest and promotes market efficiency. The law will guarantee the Regulator's independence and financial, administrative and management autonomy to exercise their responsibilities, in full compliance with EU law. The law will also contribute towards the effectiveness of the competition authority in enforcing competition rules therefore supporting and complementing the effect of the recently adopted competition law. The framework law will be submitted to parliament by [Q1-2013].

Public procurement

The government will modify the national public procurement legal framework and improve public contracts award practices to ensure a more transparent and competitive business environment and improve efficiency of public spending. In particular, it will:

7.10. Submit a report analysing the effectiveness and impact of the amendments to the revised Public Procurement Code as well as of the enhanced role of the Court of Auditors in ensuring compliance with public procurement rules by [Q1-2013].

Business environment

7.11. Make operational the procedures for requesting VAT exemptions for exporting firms and to simplify procedures associated with indirect exports as part of the "Simplex Exports" programme. [Q4-2012]

7.12. Following the plans presented at the sixth review, adopt measures to facilitate access to finance and to export markets for SMEs. A limited number of instruments should be sought, focusing primarily on SMEs, especially those in the most productive and innovative segments of the economy, while ensuring these initiatives will not pose significant fiscal risks. Progress will be reported by [Q4-2012].

7.13. Promote liquidity conditions for business by timely implementing the New Late Payments Directive. [Q1-2013]

7.14. Continue reducing administrative burdens by including municipalities and all levels of public administration within the scope of the Simplex Programme. [Q1-2013]

\section{Licensing environment}

\section{Objectives}

The government is launching a new comprehensive programme to tackle excessive licensing procedures, regulations and other administrative burdens in the economy. These explicit and implicit barriers represent a major obstacle for economic growth in Portugal. Companies face substantial costs and uncertainty which affect investment decisions, thus limiting job creation. Furthermore, 
these barriers affect small and medium-sized enterprises in a disproportionate way because they have fewer resources to surpass these obstacles, deteriorating the competitive environment. Foreign investment is also affected disproportionally because national companies have information advantages. The various new initiatives laid out below cover all families of licenses and will have a substantial impact in the business environment. The reviews of the legal regimes of environment and territory planning and of industrial and commercial licencing aim at ensuring their mutual compatibility.

\section{Regulatory simplification}

7.15. To deal with the legacy of excessive licences procedures and other administrative burdens, carry out a full inventory and an analysis of the costs of all regulations in the economy (at central, regional and local levels). [Q2-2013] On the basis of the analysis the government will devise a roadmap for a regulatory simplification.

7.16. To prevent future growth in excessive licenses and regulations, study the feasibility of a rule that prohibits at all levels of government the creation of a new regulation generating costs for businesses without the elimination of an existing regulation or regulations with an equivalent cost. The feasibility of such rule will be decided by [Q1-2013] with a view of being in place by [Q2-2013].

7.17. Create a working group to analyse and fast-track applications for the licensing of planned investment projects which are left unresolved or undecided for more than 12 months [Q4-2012].

\section{Environment and territory planning}

7.18. In consultation with the relevant stakeholders, review the legal regimes at all levels of Government in the area of territorial planning, in order to increase and facilitate the establishment of investors while at the same time limiting urban sprawl. In particular, review the following legal regimes, in the area of territorial planning:

i. new Base Law of Soil and Territorial and Urbanism Planning (Lei dos Solos), that should be aligned with the new Industrial Licensing regime (measure 7.24 ii) [Q42012];

ii. National Ecological Reserve/ Risks (REN): (1) Changes to Decree-Law 166/2008 (RJREN); (2) Publication of strategic orientations regarding modifications of REN's municipal delimitations; (3) Revocation of Ordinance 1356/ 2008 (Compatible REN actions); 4. Joint Dispatch of the Secretaries of State of Environment and Territorial Planning and of Internal Administration in order to determine the creation of Risk Sectorial Plan [Q4-2012];

iii. review the legal regimes of the Territorial Management Instruments (RJIGT) and of the related regulations [Q4-2012];

iv. diploma for the regularization of activities not in accordance with Territorial Management Instruments [Q4-2012];

v. diploma for the harmonization of Territorial Planning Regional Plans - new generation [Q4-2012]; 
vi. review the Legal Regime for Urbanism and Building (RJUE), that should be aligned with, the new Industrial Licensing regime (measure 7.24 ii) [Q1-2013].

7.19. Increase a nationwide land registration system (registo cadastral) to allow a more equal (perequitativa) distribution of benefits and costs in the execution of urban planning. The government will:

i. implement a Legal Regime of Land Registration (registo cadastral) [Q4 2013];

ii. create a diploma on Land Registration and Land Registration Experts [Q4-2013];

iii. review the cartography for plans regime [Q4-2013], and the diploma on Cartography [Q4-2013];

iv. enforce the Council of Ministers Resolution 56/2012 by Q4-2013, to collect all land registration procedures, currently scattered in various departments.

7.20. Change the legal regime for Environment Impact Evaluation in order to increase the speed and effectiveness of this regulation and reduce associated monetary and time costs. [Q4-2012].

Industrial Licensing

7.21. Implement the new Industrial Licensing regime by means of:

i. fully implement the approved Programme of Responsible Industry ("PIR - Programa da Indústria Responsável" [Q2-2013];

ii. review the following legal norms and regimes that are crucial for a successful implementation of the approved System of Responsible Industry ("SIR - Sistema da Indústria Responsável"):

a. implement zero licensing procedures for Type 3 [Q4 2012] and Type 2 industries

[Q1 2013] including fully integration of these procedures in the one-stop shop ("Balcão do empreendedor"). Implement fast-track procedures for Type 1 industries [Ongoing];

b. define and establish the Zones of Responsible Enterprises (ZER - Zonas da Indústria Responsável) by [Q1-2013], which will allow the installation of industries in areas previously licensed with all industrial, building and environmental provisions required by national and European law;

C. create and define standardized industrial licenses [Q1-2013];

d. ensure that the new Industrial Licensing is aligned with, and strengthened by, the review of the New Base Law of Soil and Territorial and Urbanism Planning while at the same time limiting urban sprawl (measure 7.21 i) [Q4-2012];

e. ensure that the new Industrial Licensing is aligned with, and strengthened by, the review of the Legal Regime for Urbanism and Building (RJUE - measure 7.21 vi) [Q1-2013]. 


\section{Commercial licensing}

7.22. Review the commercial licensing regime. Approval of a new legal regime for commercial actives and establishment of the Program for the Competitiveness of Commerce and Services activities ("Programa para a Competitividade do Comércio e Serviços), which will simplify and condense in a single law more than 20 dispersed existing legal regimes [Q4-2012].

\section{Geology}

7.23. Reviewing the geological licensing regimes, including:

i. revision of the legal regime concerning the licensing of mining and geological production and investment in line with international best practices in this field [Q42012];

ii. simplify the legal and bureaucratic procedures pertaining to mining and geological investments, especially in terms of assessment, search, development, and production activities [Q4-2012].

\section{Tourism}

7.24. Review the Licensing in Tourism regime:

i. eliminate or transforming into a voluntary regime the mechanism of prior communication in the Regime for Urbanism and Building [Q1-2013]. Simplify the legal regime for touristic establishments [Q4-2012];

ii. expand the range of ex post control mechanisms in urban operations, significantly reducing administrative procedures and costs for developers [Q4-2012];

iii. simplified and transparent requirements on the classification of the several types of touristic establishments (number of stars) [Q4-2012];

iv. review of the sanction legislation on the touristic establishments regime as a way to fight informal touristic economy, giving more powers to ASAE (Authority for Economic and Food Safety). [Q4-2012] 
This page intentionally left blank

CInternational Monetary Fund. Not for Redistribution 


\section{IMF Completes Sixth Review Under an EFF Arrangement with Portugal, Approves €838.8 Million Disbursement}

The Executive Board of the International Monetary Fund (IMF) today completed the sixth review of Portugal's performance under an economic program supported by a 3-year, SDR 23.742 billion (about $€ 27.51$ billion) Extended Fund Facility (EFF) arrangement. The completion of the review enables the immediate disbursement of an amount equivalent to SDR 724 million (about $€ 838.8$ million), bringing total disbursements under the EFF arrangement to SDR 19.126 billion (about $€ 22.16$ billion).

The Executive Board also approved a request for waivers of applicability for the endDecember 2012 performance criteria (PC). This waiver was necessary because the Executive Board meeting was scheduled to take place after end-December but prior to the availability of data to assess the relevant PCs

The Executive Board today also concluded the 2012 Article Consultation with Portugal. A Public Information Notice will be issued in due course.

The EFF arrangement, which was approved on May 20, 2011 (see Press Release No. 11/190) is part of a cooperative package of financing with the European Union amounting to $€ 78$ billion over three years. It entails exceptional access to IMF resources, amounting to 2,306 percent of Portugal's IMF quota.

After the Board discussion, Ms. Nemat Shafik, Deputy Managing Director and Acting Chair, said:

“The authorities' policy and reform effort has been impressive. Considerable progress has already been made in fiscal and external adjustment, and sovereign spreads have narrowed significantly, which bodes well for the authorities' strategy of regaining market access. Nonetheless, the near-term outlook is uncertain, and sizable medium-term economic 
challenges remain. In light of this, the authorities need to sustain efforts to make the tradable sector more competitive, boost long-term growth, and further advance fiscal consolidation.

"The fiscal objectives remain appropriate, provided economic developments unfold as expected. However, a public debate on how to best share the burden of the remaining sizable fiscal adjustment is needed. Given an already high tax burden, the expenditure review that is aimed at rebalancing the adjustment mix is welcome. Going forward, a broader tax base and strengthened compliance would help generate space for lower income tax rates, particularly for corporate income tax, with a view to fostering investment and competitiveness. Significant progress has been made on the fiscal structural agenda, but continued strong implementation will be needed to achieve durable fiscal consolidation.

"The authorities have a strong track record in preserving financial stability, but need to continue to monitor risks vigilantly. Progress has been made in keeping the banks well capitalized and adequately financed. Improved credit conditions will be important to facilitate economic recovery and ensure an orderly deleveraging by highly indebted firms.

"The progress on labor and product market reforms, as well as in the judiciary, is encouraging. However, the authorities should vigorously pursue structural reforms to lock in a durable improvement in competitiveness, growth, and employment.

"In addition to domestic efforts, success will depend critically on continued external support and successful crisis policies at the euro area level. Support from the Eurosystem is important to contain credit market segmentation and improve monetary policy transmission." 


\section{Statement by Andrea Montanino, Executive Director for Portugal and \\ José Cardoso, Advisor to Executive Director}

January 11, 2013

\section{1 - Overview}

We welcome the IMF staff reports. We note the broad appreciation of the efforts undertaken by the Portuguese authorities in implementing the program. Indeed the program is helping to correct the structural imbalances in the Portuguese economy, namely in terms of fiscal consolidation, indebtedness of the private sector, and external accounts.

The Portuguese authorities remain fully committed to the program while recognizing the need to address social and political tensions that are being fuelled by the prolonged recession and mounting unemployment. The authorities recognize that efforts to alleviate the costs of the adjustment are necessary, and are working towards the resumption of growth. The structural reforms foreseen in the program will contribute to improving the growth potential, but their benefits will only materialize in the medium term. In the shorter term, the possibility of providing policy stimulus to the economy is limited by the ongoing adjustment. However, easing the cost of financing of the private sector, which now is elevated, could provide a substantial stimulus going forward. This involves, inter alia, taking steps for the return of the sovereign to the financial markets at an acceptable cost. Recent market developments have been encouraging in this respect as some large firms and banks have been able to effectively access the international bond markets. The support of our international partners and progress in the resolution of the euro area crisis is playing a key role in this process. In particular, addressing the current fragmentation of financial markets which are impairing the transmission mechanism of monetary policy in a number of euro area countries, including Portugal, would have important beneficial consequences, as highlighted in the IMF report. Progress on this front would improve confidence and reduce uncertainty, thus creating a favorable environment for a turnaround in investment in the near term.

The recovery of investment also depends on the creation of a more favorable business environment. In this context, the Government is reforming the Corporate Income Tax that should be aligned with international best practices. The broad objectives of the reform will be discussed with the troika during the $7^{\text {th }}$ review and will be implemented towards the end of the year. By making the system more efficient and expanding the tax base, this reform should lead to lower effective tax rates on corporations in 2014.

More generally, the authorities recognize that, although the budget consolidation is excessively tilted to the revenue side in 2013, the expenditure review under way should allow for a rebalancing of the program in 2014 so that the fiscal consolidation will be achieved mainly via expenditure reduction. The expenditure review should lead to savings that will allow some room for lowering the tax burden that will be positive for growth in the medium term. Indeed, a moderate recovery in economic activity is forecasted for 2014 . This recovery could be reinforced by positive effects of the structural reforms that may start to be felt during this year. 


\section{2 - Fiscal Policy}

While final figures on the end-2012 fiscal outturns are not yet available, it is now clear that there will be a major correction of the fiscal balance in 2012. This is not apparent in the headline figures as the deficit will rise from 4.4 percent of GDP in 2011 (which was lower than the program target of 5.9 percent) to an expected 5 percent of GDP in 2012, in line with the revised target. However, it should be noted that the 2011 budget balance included around 3 percent of GDP of temporary measures, while the 2012 budget includes around 1 percent of GDP of temporary measures. A better gauge of the progress is the structural deficit which, according to the IMF staff's estimates, will decline by 2.4 percent of GDP in 2012, after showing a reduction of 2.5 percent of GDP in 2011. This is a very significant structural adjustment that shows that the fiscal consolidation has proceeded at a good pace, even against an unfavorable and deteriorating external environment.

Since the end of the review mission, we have proceeded with the work on the expenditure review. A technical mission of the IMF was held in December to help organize the work that is now ongoing with the line Ministries. The government is promoting an open discussion with the political parties and with the civil society on the role of the state that should lead to a more consensual approach to the exercise. If necessary, some of the identified measures will be frontloaded to address implementation risks.

The government has also taken decisive steps to structurally change the fiscal framework. At year-end, the Council of Ministers approved three important law proposals that will significantly enhance public financial management in Portugal.

The first was the revised Budget Framework Law, where the government transposed the new requirements of the European fiscal framework (fiscal compact). The new law gives more prominence to the structural balance and to the correction of excessive debt in line with the Treaty on Stability Coordination and Governance in the Economic and Monetary Union. The Law proposal specifies a comprehensive set of rules that significantly enhance fiscal discipline and transparency. It requires the government to take action when the deficit or the debt deviates from given thresholds. The structural balance rule states that the structural balance cannot be less than the annual goal set in the Stability and Growth Program. In addition, until the medium-term objective is reached, the annual adjustment in the structural balance cannot be less than 0.5 percent of GDP, and the growth rate of public expenditure, net of extraordinary measures on the revenue side, cannot exceed the reference rate medium-term GDP growth potential, as defined in the Stability and Growth Program. In turn, the debt rule implies that when the debt ratio, corrected by the cycle, is above 60 percent of GDP, the gap between the actual debt ratio and 60 percent needs to be reduced at a rate of $1 / 20^{\text {th }}$ per year on a three-year average.

The second and third draft laws approved in December were the local and regional finance laws. The new legislation will enhance the fiscal discipline of these sectors, which in the past have been an important source of budgetary slippages. With the approval of these laws, Portugal will have completed the main legislative reforms on the budgetary framework. While constant improvement of the legislative instruments is needed, now the emphasis will be on the operationalization and enforcement of the reinforced budgetary framework. 


\section{3 - Financial Sector Policies}

The Portuguese banking system has been strengthening its resilience to the challenges underlying the adjustment process of the Portuguese economy. These include the ongoing sovereign debt crisis in the euro area, against the background of an economic contraction in the area. On the other hand, the Portuguese economy has benefited markedly from the ECB's announcement of the Outright Monetary Transactions programme, which has eased conditions in the sovereign debt markets in the euro area as well as in other financial market segments. In Portugal, this trend also benefited from the progress in the fiscal consolidation front, which is also contributing toward the improvement of international investors' risk perception regarding the Portuguese State and systemic risk in the banking system.

The strengthening in the banks' resilience has been materializing on several dimensions. First, banks are gradually converging to a more-balanced structural liquidity position. In particular, the liquidity position of the Portuguese banks, when measured by liquidity gaps of up to one year, has improved substantially since the start of 2012, reflecting the permanent nature of financing from the ECB over this timeframe and the reinforcement of the available collateral in the context of the new eligibility rules for monetary policy operations. Reference should also be made to the gradual reduction of the loans-to-deposits ratio implying the convergence toward a financial structure less vulnerable to liquidity shocks arising from changes in international investors' risk perceptions. In this context, the new platform for interbank unsecured lending developed by Banco de Portugal, which started operating on September 3, 2012, is working smoothly, facilitating the redistribution of liquidity among domestic banks. Portuguese banks' access to the international financial markets is, however, still limited. This notwithstanding some Portuguese banks have recently issued debt in the medium- and longterm international financial markets, which marks a quite favorable development in this domain.

Second, banks have been strengthening their own funds through equity market issues, capital subscribed by the State - or hybrid instruments eligible as Core Tier 1 - and earnings retention. This allowed banks to comply with the EBA's Core Tier 1 capital requirements for end-June 2012 as well as with the solvency requirements set by Banco de Portugal for end2012. In addition, by end-2012, a small bank resorted to the Bank Solvency Support Facility established under the Programme, amounting to $€ 1.1$ billion. A total of $€ 5.6$ billion - out of the $€ 12$ billion available in the Facility - have thus been used to capitalize private banks in Portugal. The most recent stress test exercise, conducted by Banco de Portugal in November 2012, in tandem with the quarterly Funding and Capital Plans, confirmed the resilience of all participating banks. This exercise continued to reveal the importance of the capital increases carried out in June 2012, as banks were able to absorb the severe adverse scenario and yet still keep a core tier 1 ratio above 6 percent.

Third, the supervision of the banking system and the regulatory framework continued to be strengthened. Several initiatives are worth highlighting in this respect. On the one hand, with a view to discouraging evergreening of problematic loans, Banco de Portugal published an Instruction aimed at ensuring the identification in the banks' information systems of restructured credits due to financial difficulties of the borrower. In parallel, a supervisory mechanism was put in place which requires banking institutions to report those restructured loans on a quarterly basis, therefore allowing a more accurate evaluation of the credit portfolio quality of the banking system. Banco de Portugal is currently analyzing the data received (banks were required to report historical quarterly information since June 2011). On the other hand, as part of its regular prudential supervision activity, Banco de Portugal has 
been closely monitoring banks' exposures to the construction and real estate sectors, which have been particularly affected by the current macroeconomic downturn. A new On-site Inspections Programme was thus launched, aimed at assessing the adequacy of impairment levels recorded by the eight largest banking groups with regard to their exposure to the sectors in question. For the eight groups as a whole, and with reference to June 30, 2012, the Programme estimated a need to reinforce the value of impairments recorded for the exposure analyzed by $€ 861$ million, so as to reach robust provisioning levels. The estimated impact of this reinforcement on the aggregate Core Tier 1 ratio projected for end-December 2012 was negligible, and did not compromise Banco de Portugal's capital ratio requirement of 10 percent as of the end of the year.

Finally, the deleveraging of the banking sector has continued. Since mid-2010, the loan-todeposits ratio of the eight largest banking groups in Portugal was reduced from around 160 percent to around 125 percent. This compares with an indicative objective of 120 percent in 2014 for the banks individually considered. The decline of the loans-to-deposits ratio has been occurring in a context in which household deposits are still recording positive growth rates but, as expected, have been decelerating throughout 2012. Despite the maintenance of restrictive credit market conditions - rooted inter alia in heightened risk perception levels by banks - the evidence suggests that banks have not induced sizeable supply-side constraints on credit flows to the most dynamic and productive segments of the economy, including exporting firms. However, albeit declining, bank lending interest rates remained high, as highlighted in the IMF staff report. In addition, there is a high degree of heterogeneity in firms' access to the credit market. In particular, the diversification of sources of financing notably credit from non-residents and bond market issuances - is not available for SMEs. It is therefore important to safeguard that the deleveraging of the banking sector occurs in tandem with the deleveraging in the corporate sector. In this regard, authorities have been working on proposals to promote alternative sources of financing for firms. Moreover, it is also worth underlining the idea of setting-up a vehicle - in a European context - to reduce the weight of legacy mortgage credit in banks' balance sheets. This would allow banks to immediately deleverage through a stock adjustment, without impacting the financing of the economy. Further, it would allow banks to restructure the asset side of the balance sheet and would contribute to a smoother functioning of the monetary transmission mechanism in the euro area.

\section{4 - Structural Reforms}

The government remains committed to pressing ahead with structural reforms that promote the potential growth of the Portuguese economy. The IMF report provides an accurate description of the main measures being taken.

With regard to the product market, during the $6^{\text {th }}$ review the Government discussed measures that aim to reduce the costs of the use of ports which should help foster export competitiveness.

In the context of the ongoing structural reform of the labor market, and following the revised Labour Code that came into force in August, new restrictions on automatic extensions of collective agreements were set. This resolution helps to promote competitiveness of enterprises by requiring a minimum representativeness to proceed with the extension of specific conditions (for example, wage conditions) for smaller companies.

In health, we keep implementing our policy, closely monitoring all measures of cost control, 
rationalizing supply, and implementing operational improvements that have been approved in recent months. Measures, such as the compulsory e-prescription, and changes in pharmacies' margins, in international reference price system, and in pricing of generics are already yielding results and will produce important savings.

An important agreement was reached with health professionals that allowed a review of the current legal framework for the organization on working time and mobility of staff. This is also a step to improve the coverage of primary care services, which will reduce the use of emergency care in unnecessary cases. We are working on an action plan for the reorganization and rationalization of the hospital network in 2013.

Upon the adoption of the new Urban Lease, Renovation Works, and Urban Rehabilitation laws, all necessary regulations have been published to allow for the extraordinary update of the rents, for the establishment of sunset clauses in all of the old lease agreements (signed before 1990), and for the extrajudicial eviction procedures for breach of contracts.

The horizontal legal framework on public professional associations was approved in Parliament, which is an important step in liberalizing the exercise and activity of highly regulated professions. The full transposition of the EU Services Directive is proceeding rapidly, whereas the transposition of the Qualification Directive has already been completed.

Following the conclusion of the independent report on the main regulatory authorities, a new regulatory architecture is being prepared with the drafting of the regulatory framework law nearing an end.

We remain committed to following the necessary reforms to have a judicial system that contributes to improving our business environment, having a faster resolution of conflicts, and reducing the backlog cases. Upon the new Insolvency Code and the new Arbitrage Law having come into force, and also the implementation of several measures to reduce the backlog of enforcement cases, new important steps were taken, with the conclusion of the new judicial map and of the revised Code of Civil Procedure, which were submitted to Parliament.

Reducing the administrative burden for companies by simplifying licensing procedures at all levels remains a priority.

With regard to the privatization process, the government successfully concluded the important privatization of the airport concession ANA. The outcome exceeded expectations and will generate overall revenue to the state of $€ 3.08$ billion. The program goal of $€ 5$ billion in privatization proceeds is thus well within reach. The TAP privatization did not go ahead as planned, as the single bidder did not present the necessary assurances required for the transaction. The government will work to launch a new tender for the privatization of TAP as soon as possible. We reaffirm our commitment to continuing with the privatization program, which we consider to be an important tool for opening up the Portuguese economy, and to bringing new investment that will increase Portugal's competitiveness in the medium term.

\section{5 - Final Remark}

The government is fully committed to pursuing the agenda of structural transformation of the Portuguese economy in order to improve competitiveness and the potential GDP growth rate. This transformation will lead to jobs creation, sustainable economic growth, and prosperity. 